GGEAMBRICAN HUNTING DOG WARREN H.MILLER 
From the collection of the

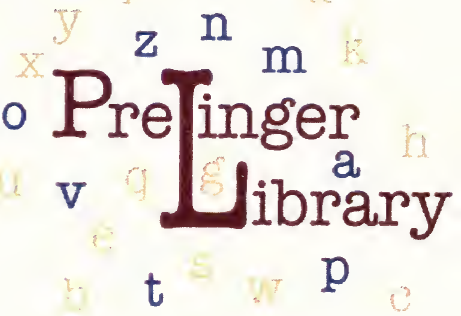

San Francisco, California 2006 


$$
\neq 35 \%
$$$$
(13114)
$$

C 350 



\section{THE AMERICAN HUNTING DOG}

WARREN H. MILLER 




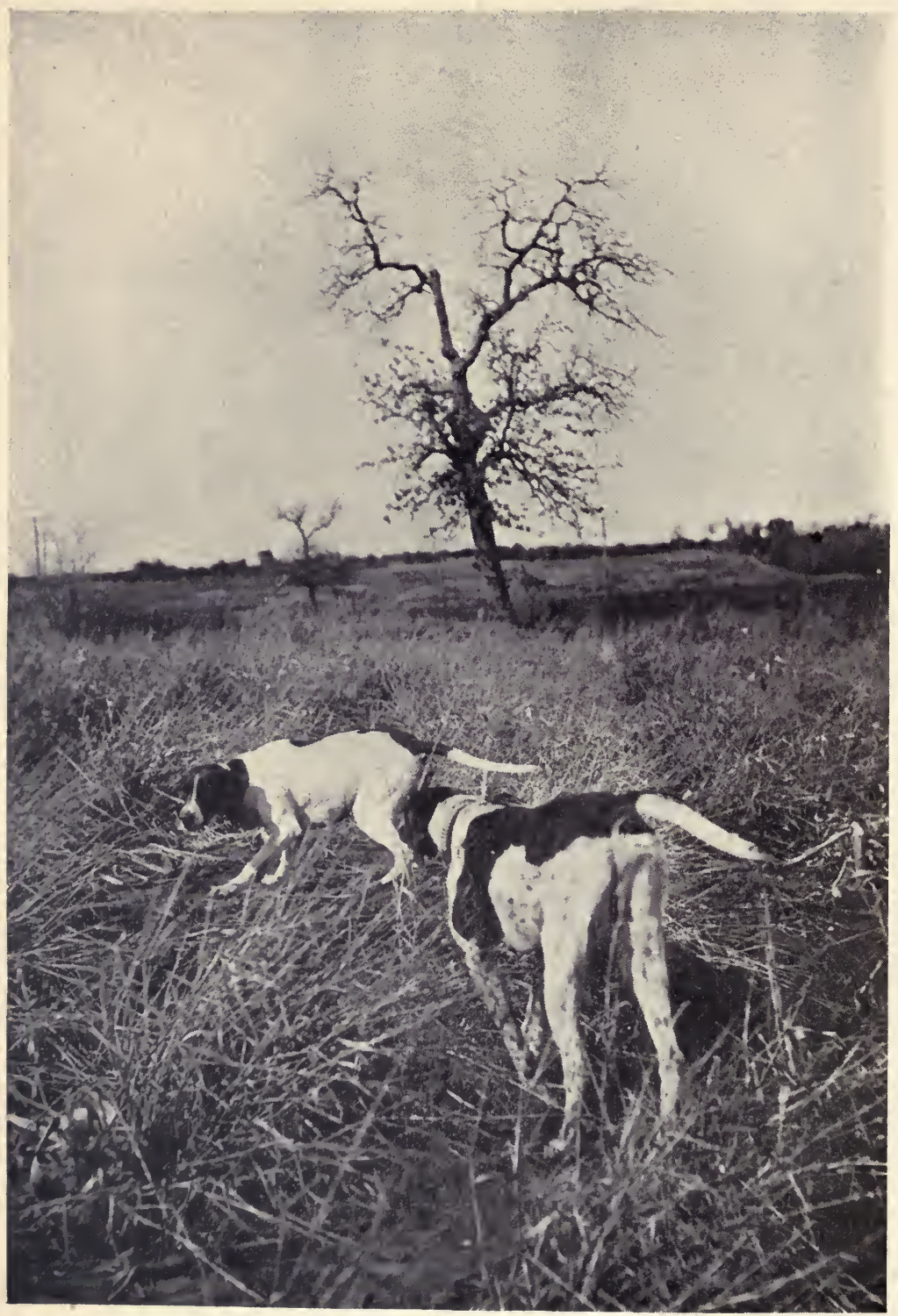

THE TENSE MOMENT-QUAIL SCE.YT! 


\section{THE AMERICAN \\ HUNTING DOG}

MODERN STRAINS OF BIRD DOGS AND HOUNDS, AND THEIR FIELD TRAINING

BY

WARREN H. MILLER

Former Editor of Field and Stream

Author of "CAMping OUt," "Rifles and Shotgung,"

"The Bot's Book of Hunting and Fishing," ETc.

ILLUSTRATED

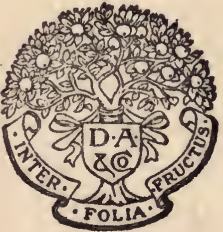

D. APPLETON AND COMPANY NEW YORK : : 1929 : : LONDON 


\section{COPYRIGHT, 1919, 1926, вт \\ D. APPLETON AND COMPANY}

Copyright, 1916, 1917, 1918, by Field \& Stream Publishing Co. PEINTED IN THE UNITED STATES OF AMERICA 


\section{PREFACE}

THIs volume is written to furnish an up-todate book confined exclusively to the breeds of American hunting dogs in use to-day. Without a dog, sports afield are apt to prove rather barren in results in the game bag. Never before have American sportsmen relied so much on the dog as a finder of game. Our coverts are depleted compared to the abundance that obtained thirty years ago. It takes the fine, sensitive gift of a dog's instinct to locate game nowadays. Without him the day is likely to be one of exasperation due to game flushing without warning or good covers hunted without starting anything. With him a satisfactory day's bag can be had in any part of our country where there is wild land, even quite near the great cities.

The love of a dog is a fine and noble thing. There is no quid pro quo in his affection. He has no thought of service for hire, nor reward for his invaluable aid, save that you love him as he loves you. All the rest is service, given freely and 
loyally. To combine this dog-love with the wonderfully gifted genius of a fine hunting dog seems the acme of canine destiny. If you are to own a dog, or several of them, why not have one that can share and appreciate your days in the great outdoors?

In all this age of hustle and change there is one subject that is timeless, perennial-dogs. They do not change-thank heaven! They are with us, as always, our hunting friends, our home guards, our bosom chums. Here in this volume we collected with much effort a rather complete Who'swho of dogdom in all the more popular hunting dog breeds. The great dog families do not change. You will find them to-day producing champions as of yore. All you have to do with the dog famous to-day is to connect him up by his dam and sire with the great hierarchies given in this book for seven generations back, and you know all about him there is to know. The matter is of importance to the dog buyer, for the pedigree of his pup is his only guide as to what sort of dog he may expect. Any pedigree sent you by a dog dealer to-day will surely connect with the pedigrees in this book or else it may be regarded with suspicion.

The subject of raising and training dogs is 
timeless. There is nothing new to offer. I wish there was one thing new, a sure serum for distemper. That dread scourge is still unconquered, but we at least have had a considerable advance in the potency of the serums in the last five years.

I would like to call your attention here to the last half of this book. It is of most unusual format. Instead of an academic discussion, I used here excerpts direct from life on all matters connected with training, feeding, and hygiene of dogs. During the seven years that I was editor of Field \& Stream literally thousands of inquiries similar to these came in to me. I doctored dogs by mail all over the country. It was part of my regular editorial work, and drew no reward save the thanks of anxious dog owners, but these letters are rich and racy with the life of hunting-dog people. You see us there, not merely talking about the sick dog but doing something for him. The same with training, correcting faults, feeding, housing, all the thousand and one things that come up in connection with our four-footed friends. I know of no more forcible way of presenting to you your own dog problems than to let you see us actually solving them, a real owner writing the inquiry, the editor replying to the best of his ability. And I'll match any human doctor as to 
viii

\section{PREFACE}

the per cent of those who died compared to the per cent who got well!

The purpose of this volume is to tell how to choose a hunting companion intelligently from the selection of dogs that are living to-day; how to raise him from puppyhood to maturity; how to train him for staunch and efficient field service; how to doctor him when he is sick and how to keep him well.

W ARREN H. MILLER.

East Gloucester, Mass. 


\section{CONTENTS}

CHAPTER

I Historical Notes on the Hunting Dog . 13

II Who's Who in Bird Dogs . . . . . . 38

III Who's Who in Hound Dogs . . . . 55

IV Spectal Field Dogs . . . . . . 68

V PUPPIES .............. 85

VI Dog Breeding .......... 105

VII Kennel Construction ........ 114

VIII Dog Training . . . . . . . 129

IX Doggr Questions ANd Answers . . . 166

X Dog Diseaseis . . . . . . . . . . 198 



\section{ILLUSTRATIONS}

The Tense Moment-Quall Scent . . Frontispiece

Chapter II: .

A Standard Llemellin Setter

Two Southern Pointers on QuaIL

Charts:

The Llewellin Hierarchy at a Glance

A Well-Blooded Irish Setter Pedigree

A Trpical Alford's John Hard-Cash Pointer Pedigree

A Pedigree Showing the Cesar-Rancocas JaCk Branch of the Llewellins

Chapter III

Typical Rabbit Beagle-Out for a Day's HUNT

Four Crack Llewellins-Odessa (pointing), Lanark Lad, Gypsy Noble, and Tonopaugh Momoney II-A Crack Field Trial Settrer

The Llewellin Setter "Boaz"

Typical Tennessee Redbone Coon Hound

Dime, Pennsylvania Coon Hound

Lady Belle B-Rabbit Beagle

Airedale Terrier, Ch. Illuminator

The Champion Pointers "Manitoba Rap" and "ALFORD's JOHN"

Chapter IV:

The Culbertson Airedales-A Famous Lion PACK 


\section{ILLUSTRATIONS}

Irish Setters, Used for Prairie Chicken

PAGE

Two Airedales with a Bear and a Lion to Their Credit

Mr. Dooley, One of the Best Bred Irish Water Spaniels in the United States Tony T. and Bessie-Noted Chesapeakes Greylock-A Fine American-Bred Griffon

Chapter V:

A Nice Litter of Setter Puppies, Two Months OLD

English Setter Pups About Four Months Old Three Pointer Pups on Point at Two Months Retriever at Six Weeks Age-Pup by Sir Roger de Coverley and Blue Girl Jane

Chapter VI:

A Graduate in Retrieving-13-Monthis Setter PUP

LOOKING FOR MOTHER

A Small Family of Chesapeakes, Husky and WELL-NOURISHED

Too Many Pups for Her to Feed Properly

Chapter VII:

Brood Matron Kennel

Kennel for Two 60-Lb. Hunting Dogs

108

96 


\section{THE AMERICAN HUNTING DOG}



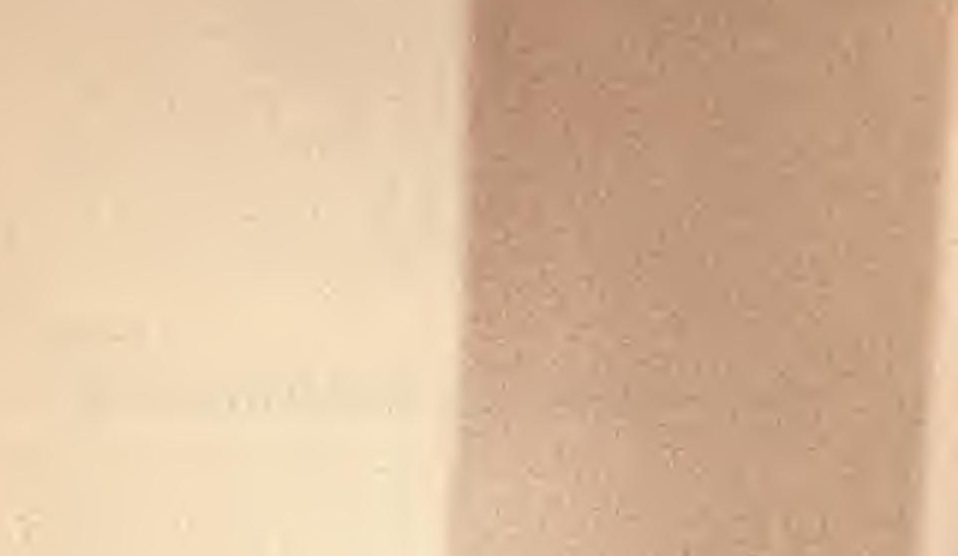

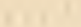

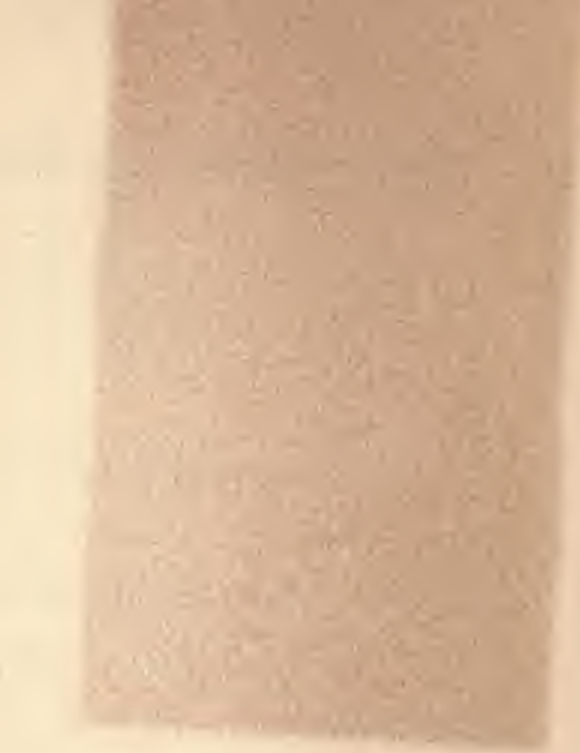




\section{THE AMERICAN HUN T I N D D G}

\section{CHAPTER I}

HISTORICAL NOTES ON THE HUNTING DOG

THe dog dates back to geological times. In the Pleistocene we have a great dog, twelve feet long, distinct from the wolf of that period, whose skeleton has come down to us nearly intact. While dogs, wolves and foxes are closely allied, the interbreeding of wolves and dogs alone is well authenticated. There is no well established account of any crossing of foxes and dogs, though I have seen several small dogs in the South that looked so exactly like foxes that one could almost believe the negro's story that a true cross had been made. It seems more improbable than a cross of wolf and dog, for the bonal structure around the eye of the fox differs materially from that of the wolf and dog, and it is a question whether the protoplasmic cells would unite.

The principal specific difference between the fox species and the wolves and dogs is in the pupil 


\section{THE AMERICAN HUNTING DOG}

of the eye, that of the fox being cat-like, in shape similar to the cross-section of a lens, and that of both wolves and dogs being round; and the fox eye, in turn, owes its shape to the bonal structure of the eye, which is the principal skeletal difference between the skull of a fox and that of dogs and wolves.

From the earliest records of man, however, the dog appears as a domesticated animal. The cave men of all periods have left both the bones of dogs, and bones gnawed by them and since fossilised, and they were undoubtedly used as hunting companions and watch dogs by our very earliest forebears.

The earliest known relic of man, except the manape (pithecanthropoid) is the skull found at Talgai, in Australia, antedating even the famous Pittsdown skull which put the ancestry of man back in the Pleistocene. The Australian skull is interesting for two reasons; it was found in deposits of a time when all the animals of Australia were marsupials, and it is surrounded with the bones of dingo dogs and marsupial bones gnawed by those dogs, besides others broken by the man. Now, as these two were the only non-marsupials in all the deposits of that period, it follows that the man must have come to Australia and brought 
his dingo dogs with him, showing a high degree of intelligence in the man and the fact that even then he had domesticated the wild dog to be his hunting companion. The vast antiquity of this skull, coupled with the fact that for no less than three times the apes have perished off the earth and been re-developed, argues that man himself is older than the apes of to-day which Darwin thought were our progenitors. Present-day geologists (even Darwin himself would so argue, if he were possessed of our latter-day discoveries): argue that, if anything, the ape is a degenerate man or an evolution from the dog, while man is sui generis, traceable as yet to no lower animal. This has long been my own theory-I have always rejected the whole of Darwin's descent of man as illogical when we consider what we know of man from his earliest records-whereas the degeneration of man is very patent, even to-day, when we can see on the earth many types that are far inferior in intelligence, devotion and conscientiousness to a good setter dog, with his highly trained reason, his sense of honour, obedience, courage, his fidelity to his duty in his sphere in life, all of such an order as to proclaim him possessed of a soul, certainly more so than are the lowest types of humans. 
Coming down into historical times, the earliest Egyptian and Biblical records contain mention of the dog, and in Egypt they had already been bred into at least two types, the guard dogs for flocks of sheep, and the hunting and coursing dogs used in the chase, both of which types are pictured in stone hieroglyphics and mummy-case decorations. Both the drop-eared and prick-eared types are represented. The latter came directly from the wolf and jackal; as to the former, no skeleton can show, but the cave men had them if a broad skull like a modern setter or hound bespeaks a lop ear. My own theory is that for the guarddog type the ear was gradually extended, due to the demands of the business for good hearing, until it fell over of its own weight, thus forming the drop-eared type. As to nose, both kinds had equally good, as witness the wolf to-day, a prickeared type which is as good a tracker as runs.

By Roman times three distinct types had been developed, called by them the sagaces (trackers), celeres (coursers) and pugnaces (fighters). Drawings and pen pictures by Roman writers would place these types as represented to-day by the coonhounds and bird dogs for the sagaces, greyhounds, wolfhounds and collies, for the celeres, and bulldogs, terriers, etc., for the pugnaces. 
The generic name "hound" comes from the same root as "hunt" and signifies a dog used in hunting. The Assyrians, Greeks, Persians, Egyptians, Romans and Teutons all had dogs for both hunting and war, and the pugnaces were as much war dogs then as any other destructive agency that could be used in augmenting military force.

The day of the Roman shaded gradually into mediæval times when the dog developed into still other types, particularly with the introduction of missile weapons. House dogs were bred small so as to be suitable for milady's boudoir, one of the most ancient lap-dog breeds being the spaniel, whose name tells us he was developed in Spain, probably in the tenth century and possibly of yet earlier lineage from the Saracens, for we find the same breed in the Chinese court spaniel, dating back for untold centuries in the Chinese records, showing that the same dog developed originally somewhere in the then populous Euphrates valley.

From the times of the Romans through the Dark Ages no record has been left of the development of the dog, but from early tapestries and paintings we note a big variety of them. The heavy dog of the Assyrians comes down into mediæval times as the mastin of the French and the mastiff of the English; the coursing dog of the Egyptians, long 


\section{THE AMERICAN HUNTING DOG}

and leggy, has his counterpart in the Scottish deerhound and the greyhound, while the hounds of St. Hubert (11th century) were quite evidently what we would call bassets to-day. The English greyhound was a much smaller and shorter legged dog than to-day and his name meant "badger" hound, later developed for speed in coursing hares as the badger grew scarce. In point of fact, even the cave man knew enough to mate fast dogs together to establish a racing type, heavy ones for war dogs, small ones for lap dogs, etc., and for this reason many breeds have been developed by a simple process of selection, just as we can breed out a bulldog cross on spaniels in eight generations.

Some of the old breeds have become extinct, such as the Irish wolfhound and the staghound, the former of which was re-established not over a hundred years ago, and the latter never having been restored, its nearest representative to-day being the Scottish deerhound. On the Continent the name "hound" was applied to all dogs; in England to hunting dogs only, the Saxon word "dog" covering all breeds. Owing to the change in type to meet new forms of chase, the breeds of the times of the knights looked littie like the animals which bear the same name to-day, and many 


\section{HISTORICAL NOTES}

of the old names have been dropped. Of Shakespeare's "Mastiff, greyhound, mongrel grim, hound or spaniel, brach or lym" how many survive as they were to-day? The brach was the old name for the coursing hound, the lym for the tracker. "Spaniel" meant three types of dogs, represented to-day by the springer, setter and water spaniel. The spaniel, undoubtedly brought from Asia to Spain by the Saracens, was first mentioned in books by Gaston de Foix, a French count who was a master huntsman with his county adjoining the Spanish frontier. His book, "Livre de Chasse," written in 1387, mentions the spaniel as the "hound for the hawk," describing a dog very like the modern field spaniel, the same as the ancient springer whose duty was to spring the game for the hawk. Once a-wing, the hawk would bring him down. Quoting Gaston de Foix:- "It is a good thing for a man that hath a noble goshawk or a tiercel to have such hounds. Also when they are taught to be cheins couchant (I give the exact French so you can get the significance of it) they are good to take partridges and quail with the net. And also they are good when they are taught to swim for fowls when they have dived. ..." Here, before 1387, we have the beginnings of all three modern dogs, the 


\section{THE AMERICAN HUNTING DOG}

springer, setter and the water spaniel, all developed from a silky coated, white or speckled dog with a docked tail (even then) which was feathered if allowed to grow. The battle of Crécy was fought in 1342; Poictiers in 1356, and no doubt Gaston de Foix came up from his huntings in the south of France to take part as a mailed knight in both of these battles. A print in Count de Foix's old book shows three of his spaniels, a large wavy coated dog with long bushy tail looking something like a modern setter, two coursing hounds, and two lyms or tracking hounds, both pairs dropeared. The spaniels are shown springing into the air on hind toes with fore feet outstretched, much as a cocker spaniel does to-day, and barking, evidently scaring birds into flight for the talons of the hawk.

In 1576 Dr. Caius describes all three spaniels as different varieties, "The Dogge called the Setter or Canis Index, and the Dogge called the Water Spaniell or Canis Aquaticus," being described as to appearance and usage at great length. We quote his description of the setter of 1576 . "Another sort of dogge be there, seruiceable for fowling, making no noise either with foote or tongue, while they followe the game. These attend diligently vpon theyr master and frame theyr condi- 
tions to such becks, motions, and gestures as it shall please him to exhibit and make, either going forward or drawing backeward, inclining to the right hand or yealding to the left. When he hath founde the byrde he keepeth sure and fast silence, he stayeth his steppes and will procede no further, and with a close, couert, watching eye layeth his belly to the grounde and so creepeth forward like a worme. When he approacheth neere to the place where the byrde is, he layeth him downe and maketh a marke of his paws, betrayeth the place of the byrdes last abode, whereby it is supposed that this kind of dogge is called Index, setter, being indeede a name most consonant and agreeable to his quality." Sounds like a page from Field and Stream, describing the work of a setter this year of grace 1918, yet this was before they began "shooting flying" at all, the first arquebuses used in birding being of date around 1583, when that beautifully inlaid, gem-incrusted, light hunting arquebus was made for Henry IV of France.

The water spaniel was bred for close woolly coat and used much as in present times, to retrieve ducks, chase "crips," and besides to retrieve floating arrows and crossbows bolts, which function has of late fallen into some disuse. In general he has changed little from that early date in ap- 


\section{2 THE AMERICAN HUNTING DOG}

pearance, not nearly so much as has the setter.

With the introduction of wing shooting with arquebuses and the decline of hawking, the pointer came forward. Hounds of the foxhound size were employed to find single birds, which were then flushed and shot on the wing. The setter was still kept for net service, which was, curiously enough, considered the higher form of sport and the more aristocratic (probably because of the then newness of wing shooting for single birds!). In one of the old books occurs the following odd line: "The setter cannot be degraded into a pointer, but the pointer may be elevated to a setter, though of second class." This idea probably had its origin in the fact that the pointer could not then be depended upon to be staunch; in fact, was required both to find and flush birds, which would never do in a setter, who had to hold his point while the netters went around on the other side of the covey and drew the net, the birds rising away from the dog, and thus flying right into the net. Only the best table birds were selected from a catch, and a balance maintained between cocks and hens caught, the rest being liberated, so the ancient sport of netting quail was not as unsportsmanlike as it looks. Once scattered in thick brush the pointer came into his own, and as soon as wing shooting 


\section{HISTORICAL NOTES}

became a fine art, about 1690 , the net was abandoned and the setter followed him as a gun dog.

Modern English setter history begins with Edward Laverack's book, "The Setter," published about 1835 . By that time the breed, as we now know it, had been well established from the setting spaniel of 1600 , and a number of notable strains had been established by the sporting nobility of England. In these latter days, after all the rumble-bumble about Laveracks and Llewellins has died down, it seems curious that those earnest controversialists should have overlooked the fact that Mr. Laverack did not have the only strain of English setters, but only one among many. There are hundreds of thousands of setters to-day who owe their descent to neither the Laverack nor the Llewellin strain. True, Mr. Laverack did get up a happy nick that gave him dogs which could sweep all before them at the English field trials, and so were in great demand, but he did not, in the nature of things, produce from his two dogs Ponto and Old Moll, more than a very small percentage of all the English setters in "blighty." However, from these two came Pride of the Border and Countess, two notable dogs ; besides Dash, Dash II, Old Blue and Fred IV. Between Ponto and Dash II are six generations, thirty-nine years 
24 THE AMERICAN HUNTING DOG

of breeding, during which time a large family of prize English setters were developed in Mr. Laverack's kennels. The dogs which interest us of this strain were Pride of the Border and Fairy, which latter came over in whelp to Blue Prince, a son of Pride of the Border. Forty-six of their descendants in this country became well-known dogs and established the Laveracks here. Later more Laveracks came over, Albert's Ranger, Albert's Woodcock, the Vandergrift dogs bearing the kennel prefix Queen (such as Queen's Place Pride, Queen's Flora, etc.), and then the Bloomfield Kennels, Mallwyd Sirdar, Stylish Sergeant, Dido B., Mepal's Queen B., Pera, etc., from which we can pick up and place many of the kennel names on present-day pedigrees.

Meanwhile Mr. Llewellin's dogs, starting with Count Wind'em, Count Noble and Gladstone, made a tremendous drive in America. They were born field trial dogs, full of speed and sagacity, and their get established the Llewellins over here. This is gone into more thoroughly in our chapter "Who's Who in Bird Dogs," but for the purposes of this historical chapter it will suffice to point out that a great deal of harm was done to the true setter type by judges giving great field trial winners place above those bred true to type. The 
Llewellins were bred to great field dogs, regardless of conformation or bench points and, while this was a good thing for quail-shooting dogs all over the country, it should have had no place in a judge's estimate of a dog's worth as a true type of English setter. There has been a lot of argument about the name Llewellin as being unfair, because a lot of dogs under that name have no right to it as not being descended from the first Duke-Rhoebe cross with the Laveracks. This is all beside the mark; the name Llewellin is very much needed, in describing a division of the English setters, bred for field trial work and not necessarily conforming to bench-show standards, and if it should be named after any one that man should certainly be Mr. Purcell Llewellin, who established this remarkable strain as a fact in the sporting world. The Gleam dogs, the Whitestones, and a lot of others are not true Llewellins, but this has little to do with the matter. Time and again an outcross of Laverack or other English setter stock has been beneficial in improving the original Liewellin blood, therefore by all means let us have the cross, and yet class the dog as a Llewellin, this being still his principal characteristic. Many of the field trial winners to-day are great little game finders and great setters, but if they are true English set. 


\section{THE AMERICAN HUNTING DOG}

ters, bred to the fixed type of the animal, then the present bench-show winners are not setters! The sportsman of to-day will bear in mind that for our widespread quail covers we need a dog of the Llewellin type, bred for generations for fast wideranging work; for grouse and all close covert work the English or Laverack setter will give him better satisfaction as he is closer to English forebears used to that kind of shooting.

The history of the pointer starts with firearms used for fowling, the type having been begun as a breed about 1650. Early prints and paintings of the date of 1530 show a smooth-haired houndy dog on point at ducks and birds with one forepaw raised, while the hunters creep up on the birds with matchlocks. These birds were shot sitting, the dogs being used to find the birds and point them, and this was undoubtedly the original pointer. In 1711 the poet Gay wrote:

"See how the well-taught pointer leads the way, The scent grows warm; he stops; he springs the prey;

The fluttering coveys from the stubble rise And on swift wing divides the sounding skies; The scattering lead pursues the certain sight And death in thunder overtakes their flight." 


\section{HISTORICAL NOTES}

This was shortly after the introduction of the flintlock as a fowling piece. It was invented in 1630 , but did not come in to stay until the latter half of the sixteen hundreds, and this poem is one of the earliest mentions of wing shooting. A very good pointer is shown in a painting of date 1786, white with black saddle and ticks, of good conformation and much like our modern animal, showing how far he had progressed since 1711. Like the setter, the pointer was a standard gundog breed in the kennels of the great lords, and so a number of notable strains were developed, such as the Duke of Kingston's black pointers, Col. Hamilton's double-nosed Spanish pointers, the rough-coated Russian pointers owned by the Earl of Powis, etc. A great number of Spanish and Portuguese pointers were brought to England and crossed on the native stock. The Spanish pointer was heavy-bodied and small-headed in comparison to his size, and his influence shows to-day in the heavy buttocks of many of our pointer families. Crossing foxhounds and setters on pointers to get a faster dog was much practiced; at that time the owners seeming to care little for the very much better plan of selective breeding from the type itself-so little were the laws of heredity and atavism known. 
In 1807 the pointer became fairly well typed, Col. Thornton's Pluto and Juno being characteristic specimens, heavy-bodied dogs with small heads and ears. Pluto was jet black and Juno lemon and white, but there were plenty of tricolours even before that time. His dog Dash became famous and sold for some $\$ 1,2 \mathrm{CO}$. He had one-third cross of foxhound with a correspondingly brushy stern, carried hound fashion, but this seems to have been no particular detriment.

Modern pointer history begins with $\mathrm{Ch}$. Bang. This remarkable dog flourished about 1879-80, and there is hardly a pointer to-day which does not trace back to old Bang along at least one line, generally two or three in-crosses of him, Jingo, Mainspring, Ch. Mike, Ch. Priam, Young Bang, Rip-Rap, and King of Kent are all Bang dogs. All the Graphic, Croxteth, and Vandervort's Don dogs are descendants of Bang. In our chapter on "Who's Who in Gun Dogs," if you turn to the pedigree of Rags Royal Pauper you will find that all the sires and most of the dams in his fifth generation ancestors are Bang dogs, son or grandson of the old boy. With that pedigree in hand, and this chapter, you have the whole history of the pointers, from the pointing hounds down to the present stud dogs, spread out in an unbroken 


\section{HISTORICAL NOTES}

genealogy. Bang himself was a son of Hamlet out of Vesta. These dogs in turn trace back to Juno. Of other prominent pointers, whose names you will come across in pedigrees contemporaneous with Bang, are Beulah, dam of the great Beaufort; and Sensation, grandson of Hamlet. Beaufort is another Bang dog, being out of Beulah by Bow, son of Bang, and Sensation is still another of the same line, being descended from Hamlet, father of Bang.

Turning now to the hounds, we find back in 1646 beagles, harriers, greyhounds (the old badger hound), brachs or coursing hounds like the Scottish deerhound, and lyms, trackers like our modern bloodhounds and coonhounds. The painting by David Teniers of that date shows how much the game and fish caught by the lords' hunting establishment had to do with his meat supply. The butcher in those days had little trade. The noble's land, with its sea frontage and brooks full of game fish, produced all the meat needed, and it was conserved from year to year so that there was a plentiful supply. The head falconer had charge of all this work, and an important personage he was, too. The ancient appeal of this living from the land's bounty in wild life, as well as on its agricultural product, moved Teniers to make 
a painting of his own kitchen, showing the head falconer surrounded by his dogs receiving the day's toll of fish and game. Older men, the fishermen, are bringing in salmon and sea fish, while young and lusty varlets, the under hunters and game keepers, attend to wildfowl, hares, haunches of venison, partridges and pheasants, all of which are shown in the greatest profusion. The dogs are interesting as showing distinct types of beagles, harriers, and coursers, looking very like the modern greyhound. The older grey (badger) hound, a leggy dog, thin and wiry, yet not over knee high, is also in the picture.

Foxhounds and beagles interest us principally as being the two great American hunting dogs, for the useful and ubiquitous coonhound was later developed as a foxhound and bloodhound cross, while the beagle is bred both small for rabbits and large, almost a counterpart of the harrier, for hunting snowshoe hare in our northern tier of states. In 1735 the first foxhound came to be known as a distinct breed for coursing and tracking foxes. The greyhound alone would not do; he had to be crossed with a tracker to give him the necessary scent. During the nineteenth century breeding to type was carried on extensively, and numerous hunt packs were established all over 
England, while the Henry strain was started by importation in America. Washington's hounds, like those of most of the Virginia gentry, were importations from England and Ireland, which, when worked in this country under our own conditions, gave rise to a faster, rangier type of dog, more suited to our own country, and selection from their descendants gave rise to the type American foxhound, now recognised as distinct from the English, and not judged from the same standards. This breed, and the development from it of the coonhounds, will be treated in the chapter on Who's-Who in Fur Dogs.

The beagle is a very old breed of hounds, being first mentioned in 1475, when he was, as now, the poor man's dog for coursing rabbits. In America he is an institution, for no better rabbit dog ever lived, and we use him for all small game as the terrier is used in England. In 1558 the beagle had become well patronised by royalty and was painted by court painters, so that we know his type to have been already well established, a small hound with long, drooping ears, short pudgy body and throaty neck. Queen Elizabeth had a kennel of them, and one hundred years later George the Third (well beloved of these American colonists) had a painting made of himself with his beagle pack. They 
appear to be small hounds, true to type, and a later painting of date 1800 shows Col. Thornton's beagles, quite the same as the modern bench winners. Their history in America begins with General Rowett, of Carlinsville, Ill., who got some of the very best stock to be had in England, and a Rowett beagle became the most sought-for of dogs by our own breeders. This takes us down to the recent history of the breed, carried on down to present stud dogs in the chapter on Whos-Who in Fur Dogs.

A brief summary of the two spaniels will conclude this chapter. Of course, the first hunting spaniel was the springer or hawking spaniel, an active, noisy, rather large dog of the spaniel type, whose work was to spring birds for the hawk. With the introduction of firearms a smaller, quieter dog was wanted, and the cocker (or, as previously called the "cocking spaniel") was got by selective breeding. Coming along at the same time as the setting spaniel, which later became the setter, was the water spaniel, now seen in the modern Norfolk and Irish water spaniel. The springer had nothing to do with the modern Welsh spaniel or springer, but was named for his function in hunting, and from him was developed the modern field spaniel. This dog has had 
an unbroken line of popularity, particularly in England, but it was not standardised as a type until 1876, which brings it too far down into present-day history for this chapter. The cocker developed with the flint lock, considerable mention of him being found in works dating from 1725 to 1813, when he had much the same characteristics as now, a low, broad, short-legged, long-haired dog. In general the cocker remained a small edition of the springer until about 1880, when attention was given to breeding to a fixed standard and a nice lot of dogs began to be shown in America. By that time the Obo strain had been well established in England, and Obo II came over, a puppy imported in utero, dam Chloe II by Obo. To Obo II we owe the present excellence of the cockers of America. At the same time were imported Miss Obo II and Obo Jr., which gave further impetus to the strain, and succeeding these came the Canadian-bred Black Duke, the best cocker shown in America. Duke Royal, son of Ch. Romany Rye, set the pace on the Pacific Coast, and succeeding these came Black Pete and Doc, who later became the property of Mr. Wilmerding. Doc sired Red Doc and La Tosca, two more good ones, and this brings us down to present-day pedigrees, treated more at length in the chapter "Who's-Who in 


\section{THE AMERICAN HUNTING DOG}

Bird Dogs." It should be noted that when Doc went to Mr. Wilmerding he became the property of a sportsman who worked him on game, thus reviving the useful side of the cocker. Not one in fifty spaniels to-day ever see a covert or scent game, so that no wonder their progeny are gunshy, poor hunters, and require a lot of careful training. Yet all over the east there is no better hunter for cock and grouse than this same cocker.

The water spaniel is so odd in every particular that he represents a wider development from the original spaniels than even the setter. Big, rangy, with tight curly hair, a spike tail with no brush, this is an odd, specialised type that has come down to us through many centuries. Except for colour of coat and a few minor points, there is not much to differentiate the Norfolk and Irish water spaniel; to us Americans they may be the same dog. The Irish is red, in solid colour, the Norfolk, liver and white, with liver ticks and with no topknot over the smooth part of the face. Both are wonderful water dogs; and have it in their blood since the earliest hunting times, when they were sent out not only for game, but for arrows and bolts, and were even required to dive after fowl that had escaped the hawk, or had been wounded and had clung to the bottom after the fashion of ducks. 
Used for hunting exclusively, they suffered from no degradation to mere bench-show breeding, and puppies got to-day can be depended upon to be wonderful hunters, with good nose and all the affectionate spaniel traits. Here is a description of him written by Dr. Caius in 1570. "This kinde of dogge is properly called Aquaticus, a water spaniel, because he frequenteth and hath usual recourse to the water where all his game \& exercise lyeth, namely waterfowles, which are taken by the helpe and seruice of them in their kind. And principally ducks and drakes, whereupon he is lykewise named a dogge for the ducke, because in that qualitie he is excellent. With these dogges also we fetche out of the water such fowle as be stung to death by any venomous worme, we vse them also to bring vs our boultes \& arrowes out of the water (missing our markett) whereat we directed our leuell, which otherwise we should hardly recouer, and oftentimes they restore to vs our shaftes which we thought never to touche or handle againe, after they were lost, for which circumstances they are called Inquisitores, searchers and finders."

That was 350 years ago, but you will find the water spaniel just as good a duck dog now as then. In America only a few years ago Mr. James 


\section{THE AMERICAN HUNTING DOG}

Watson, the famous dog authority, wrote that, "It is almost as a curiosity that we must now view the Irish water spaniel, and not as an essential in wildfowl shooting," yet of late years conditions have changed and we must now have either him or the Chesapeake. The latter is well described in our chapter on special bird-dog families, as are also the Irish water spaniels now at stud. Before them came such dogs as Barney, Mike, Skidmore's Shamrock, Judy, Old Irish Nell, and The O'Donoghue. Mr. Olcott also had Chippewa Belle, a daughter of Irish Queen, who was by Barney. Chippewa's sire was Dan, who was by Ch. Mike, the Shamrock dog. Mr. Carson later brought out Marguerite and Musha, and then came Dan Malone, while Ch. Poor Pat and Erin's Float, brought over by the Rev. T. Moore Smith of Scotch Plains, N. J., brings us down to present-day stud dogs.

Of the griffons and retrievers there is little to mention here, the early history of these breeds being covered in the chapter Who's-Who in Bird Dogs, and of the special divisions of setters, spaniels and the like, most of them belong to such recent bench standards as to deserve no particular mention in a general historical treatise. The ahove will give the dog-loving sportsman a fairly 


\section{HISTORICAL NOTES}

good panoramic view of the evolution of his favourite breeds. Like the gun, and the art of hunting itself, it is a story going far back into the dim past, so far beyond the earliest records of science and agriculture that we have only to glimpse that shadowy figure of the Taigal man and his dingo dogs, who visited Australia in Pleistocene times, to realise, not only how ancient is man, but how ancient, also, is his trusty dog. 


\section{CHAPTER II}

WHO'S WHO IN BIRD DOGS

THE life of a dog is but a short span of years and for that reason the champion of to-day becomes the stud dog of to-morrow and shortly we hear no more of him. Meanwhile his name and fame has crept into books which far outlive his brief existence, and the dog's name graces numerous pedigrees; his fame is secure in imperishable type and the world knows that here is, or was, a great dog and a mighty sire. The sportsman owning a fine bitch decides to raise some pups to keep for him her good qualities after she will have passed away, and the question of what dog to send her to at once presents itself. To the regular breeder this is no quandary; he has at his fingertips the names of all the producing sires in the country and just what blood strains they represent, and the advertising pages of his favourite kennel magazines bristle with stud-dog cards, so that he can pick and choose at will. But to the 


\section{WHO'S WHO IN BIRD DOGS}

average sportsman who does not specialise in dog breeding, yet owns a few trusty canine hunting companions, the problem of how to breed his bitch and where to send her is quite difficult to solve. The sportsman's interests centre around his guns, rods, canoes, outdoor gear, boats, dogs-everything in the wide world of the great outdoors, and he must know a little about each without specialising particularly on anything. To learn where to breed his dog he refers to the dog books in his library, but, while these are full of the names of champions of yesterday, and lay down the pedigree lines of all the well-known dog strains, virtually every dog mentioned in the book turns out to be either dead or retired, or, if still in the stud, too old to produce really good pups. Even the stud advertisements of the present-day papers are practically Greek to the average sportsman; the names mean nothing to him beyond that the dog is evidently famous, though of what family he comes is a sealed book to the sportsman, though plain as daylight to the breeder.

Again, it depends upon what you want the dog for, if an intelligent selection of a sire is to be made. To send your grouse and woodcock bitch to a champion field trial sire, bred for speed and quail in the open, is to invite trouble, for the re- 


\section{THE AMERICAN HUNTING DOG}

sulting pups will be far below their mother's standard as grouse dogs. You do not want range and speed in a thick cover dog; you want, rather, a dog that will work close; quiet and catlike; with a keen nose for the faint grouse scent-and the rest is experience. So send her to a grouse sire if you want pups that will be natural grouse hunters, easy to train. Another consideration is to avoid inbreeding and the constitutional weakness that is the sure result of it, for you do not want to lose your dog from distemper after spending a lot of time and money on him and giving him a place in your heart that will ache for many a year after he is gone. If dam and sire are of the same immediate ancestors the pups will be badly inbred, but if of different families, harking back to remote common ancestors with many outcrosses, you can count on strong, hardy pups that will also be good hunters. But do not look for the exact qualities or markings of either dam or sire in them. The family traits will be reproduced with exact fidelity, but the individual pups will take after grandsire, granddams, ancestors of the third and fourth generation, etc., one or two of them perhaps being good copies of the dam and sire themselves, though even then possibly not inheriting their mental traits. 


\section{WHO'S WHO IN BIRD DOGS 41}

A little history will be first in order, after which the family position of various dogs now in the stud will be more clear in the reader's mind. Beginning with the English setters, we will confine ourselves to the Llewellin or field trial setter, including the Laverack outcrosses, as many good bird dogs have been recruited from the ranks of the latter also. Many of the field trial setters of to-day are half Llewellin and half "English" as the generic name for a Laverack outcross from the original Llewellin stock is termed by breeders. This does not impair their hunting qualities at all but rather improves their physical stamina and mental makeup. The straight Llewellin stock descends from a few dogs originally imported into our country from Mr. Llewellin's strain of dogs originated by him in England, which strain, the famous Duke-Rhoebe-Laverack cross, showed so many fine field qualities that they became instantly popular here. The blood of these dogs is in nearly all the great field trial dogs that have won stakes here in the past two decades.

The first famous Llewellins imported here were Gladstone and Count Noble, the latter a son of the great Count Wind'em of England. By Count Noble came Ch. Count Gladstone IV, who, to. 
gether with Roderigo, Gath's Hope and Gath's Mark, founded a great strain of American field dogs. These were by the happy combination of Gladstone's daughters bred to Count Noble, and established high-class setters once for all in our country, for, look at the long list of great dogs bred from these four. To Roderigo we owe, via Antonio, Jessie Rodfield, Lanark Lad and Tony Boy, to whom in turn we owe a number of great dogs such as Ch. Mohawk II, "the blazing soul of Roderigo," from whom come the Babblebrooks of to-day. To Count Gladstone IV we owe Ch. Lady's Count Gladstone, Count Danstone, Ch. Sioux and Prime Minister (from whom we get Count Bloodstone and Momoney of to-day). The first two of these dogs are not straight Llewellin, to the purist's point of view, as their dam was Dan's Lady, who has Dash III's blood in her, a Laverack dog out of a Laverack dam, making a straight outcross, yet Lady's Count Gladstone gave us Jessie Rodfield's Count Gladstone and Count Whitestone, and the latter gave us Ch. Pioneer and Ch. Prince Whitestone. At the same time Count Danstone sired a number of famous dogs now in the stud. Both of them are now classed by all breeders as straight Llewellin, the outcross being so far back. 


\section{WHO'S WHO IN: BIRD DOGS}

We must not forget the great producing dams in this sketch of the setter families. Gath's Mark gave us Ouida F., mother of Dolly Manners by Tony Boy, which latter dam (Dolly) gave us Cæsar and Dolly Manners II. Gladstone, bred to Ruby II, gave us Ruby's Girl, the mother of Count Gladstone IV and Ouida F. Jessie Rodfield, Antonio's granddaughter, was granddam to a number of noted dogs such as Count Whitestone and Jessie Rodfield's Count Gladstone. The sixgeneration pedigree of Blue Danstone's Duke, printed herein, gives a very good bird's-eye view of all the noted setter families which we have been discussing and is a typical Llewellin setter pedigree.

Turning to dogs now in the stud we note such names as Doc Whitestone, Gleam's Gladstone Max, the Babblebrooks, Eugene M., Boaz, Master Rodfield, Stedman's Count Whitestone, Count Bloodstone, Momoney and Momoney II, Free Lance, Master Ben, Sport Hiki, Ch. Candy Kid, Ch. Benstone, etc. Who are they? The very names of many of them place them at once. Doc. Whitestone (Count Whitestone-Marian Mills II). The Gleam dog, son of Count Gleam, who was a son of Ch. Lady's Count Gladstone, the original Gleam being a Laverack (Lincoln-Blake); the 


\section{4 THE AMERICAN HUNTING DOG}

Babblebrooks, sons of Ch. Mohawk II; Momoney (Prince Algonquin, son of Prime Minister-Una, daughter of Mohawk II); Master Ben, son of Marse Ben, a Gleam dog; Sport Hiki, another Gleam dog; Eugene M., national champion; Ch. Candy Kid, second in the All-America in 1916 (Vallejo-Bond's Gypsy), a Pacific Coast breeding; Free Lance (Mohawk II-Lady Freakstone); Master Rodfield (Ruby's Dan II-Marie's Sports Topsey); Ch. Benstone (Ch. Ct. Whitestone-Mayme Gilchrist-a daughter of Marse Ben).

In all this welter of Llewellins we must not forget the Laveracks, which are the setter fountain head. Alongside the characteristic black ears and partly black head, with white parting line and the prominent forehead stop so characteristic of the field trial setter, we must ever bear in mind that long, lean head, all white with tan spots, $\tan$ ears and gentle forehead stop, which speaks the Laverack dog. For, as many of these pedigrees show it is the Laverack cross that saves the Llewellin from inbreeding and invariably produces the great dog of the next generation. Look at the original Gladstone bitches, full of Laverack blood which, bred to Count Noble, produced the heads of our winning setter families in America. 


\section{WHO'S WHO IN BIRD DOGS}

Look at the Count Whitestone bitches, of some 50 per cent Laverack blood through Queen Stella, bred to Mohawk sires to-day to produce Derby winners. And some of the best grouse dogs in the country have been straight Laveracks, notably Sir Roger de Coverly, Ch. Deodora, Albert's Mallwyd Mixture, Ch. La Besita, recent national champion. During the last two years the notable preponderance of pointer wins in the field trials has been due undoubtedly to too great inbreeding of Llewellins, while the increase in setter wins of 1915 and 1916 shows up clearly, in the fresh outcrossing of Laverack blood. In general it would be the best side to lean to, in breeding grouse dogs for eastern woods shooting; by all means send your Llewellin bitch to a noted Laverack grouse dog or his get if you don't want to have the disgust of hollering your head off at a wide ranger who makes more noise in the dry leaves and flushes more grouse than you will see in a day's march, which will likely be your fate if your pup is of straight field trial stock.

Taking the pointers of to-day we need not go much farther back than four or five great names that began to compete with the setters successfully some seven years ago. Fishel's Frank, 


\section{THE AMERICAN HUNTING DOG}

Hard Cash, Manitoba Rap, Alford's John, Jingo, Hal Pointer-these are the dogs we really started with. They began with imported King of Kent, Mainspring, Hops and Pontiac. King of Kent and Hops gave us Rip Rap, who starred in the field trials of 1889, becoming finally field champion. Hard Cash owns Jingo and Hal Pointer as grandparents. Fishel's Frank is a combination of Jingo and Rip Rap (Fishel's Rip Rap-Boy's Queen, a Jingo dog) ; Alford's John, the great discovery, is of Lad of Kent extraction, his father being Dave Kent. He was discovered and brought into the field trial limelight by the merest accident, and his get are among the prominent winners today. Manitoba Rap is by Ripple, ex Lady Cyrano, the former a grandson of Rip Rap, and Lady a daughter of King Cyrano. Turning to the dogs now in the stud, we find Silver Sides (Ch. Manitoba Rap-King's Sister), Ch. Comanche Frank (Fishel's Frank-Lady Johns, a daughter of Alford's John), Rags Royal Pauper (Hard CashAlford's Royal Pauper), which ought to place him as a grandson of Alford's John, the royal pauper of dogdom. Then there is Champion John Proctor (Fishel's Frank-Miss Mariutch), Security (Hard Cash-Alford's Royal Rags), one of the best 
ever brought out, and Lewis C. Morris, the champion of to-day (Fishel's Frank-Bessatina).

This gives a fair line on the pointer families in the lead to-day, and the sportsman wishing to breed his bitch can choose from any of them not of his own direct line and avoid inbreeding, yet get a high-class field dog for the sire.

Now, who won in the 1916 big field events? Beginning with the United States Field Trials, held at Grand Junction, Tenn., first was won by Joe Muncie, a white and lemon setter dog by Jack Muncie ex Miss Mathews. Second place was taken by Lewis C. Morris, the Fishel's Frank pointer just described. Third was won by Security, the pointer combination of Hard Cash and Alford's John via Alford's Royal Rags. In the Derby, the dogs whelped after January 1st of the year previous, insuring the competitors to be puppies in their first year, first was won by Kirk's Buss (Wise's Ruby's Sport-Kirk's Maude), a Llewellin-Laverack white and orange setter dog; second by Naponechee (Dan Piedmont-Lady Reyno), a Llewellin; while third was divided between Commissioners O'Crahu (CommissionerCount Whitestone's Lady Alice), which places him, and Rap's Pansy Blossom (Manitoba Rap- 


\section{THE AMERICAN HUNTING DOG}

Fishel's Missey)-'nuff said! In the National Field Trial Club's events, held at Calhoun, Ala., first was taken by Lewis C. Morris, second by Gibraltar Ollie (Gibraltar-Comanche), a white and orange setter bitch, and third by John Proctor (Fishel's Frank-Miss Mariutch). Among the pups we find Gunner running first, a Free LanceCotton Blossom dog; Attakapas Rap (Manitoba Rap-Lady Ferris), second, and King Cy (John's King-Bird's Dakotah Pride), third, a pointer belonging to the Alford's John-King Cyrano tribe.

In the All-America trials held at Denbigh, N. D., Lewis C. Morris again took first, Frank's Den (Fishel's Frank-Becky Cott), second, and Candy Kid (Vallejo-Bond's Gipsy), a white, black and tan Llewellin setter, third. In the championship stakes Candy Kid won the coveted first and Joe Muncie, of United States Field Club fame, was runner up, both setters. At the important Southern Field Trial Clubs events at Leetohatchie, Ala., the all-age was won by John Proctor's Sister, same breeding as John Proctor; second by Medford Eugene, a Eugene M. setter dog, and third by the pointer Adam G. (Rags Royal Pauper-Miss Wing!. 


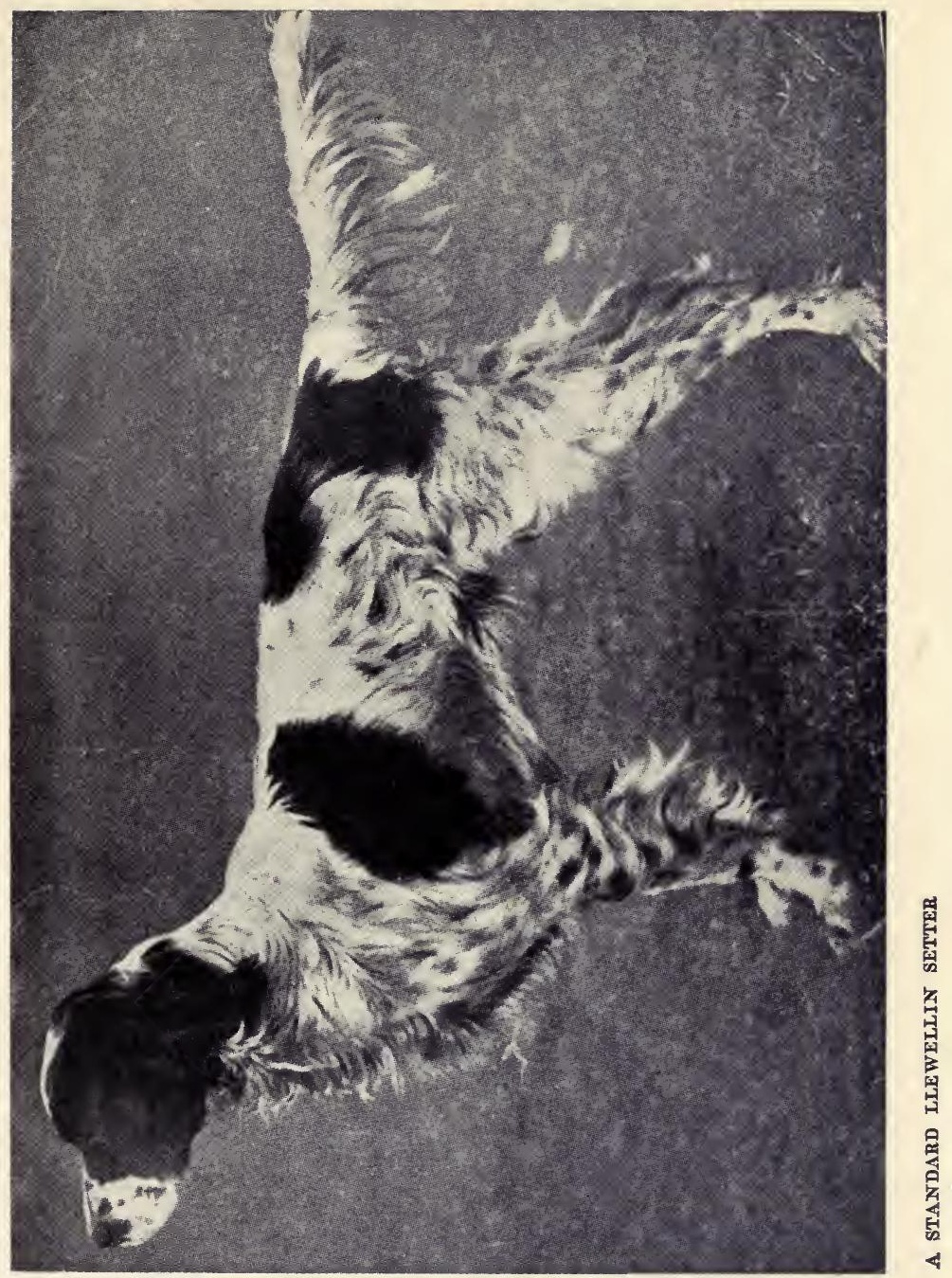




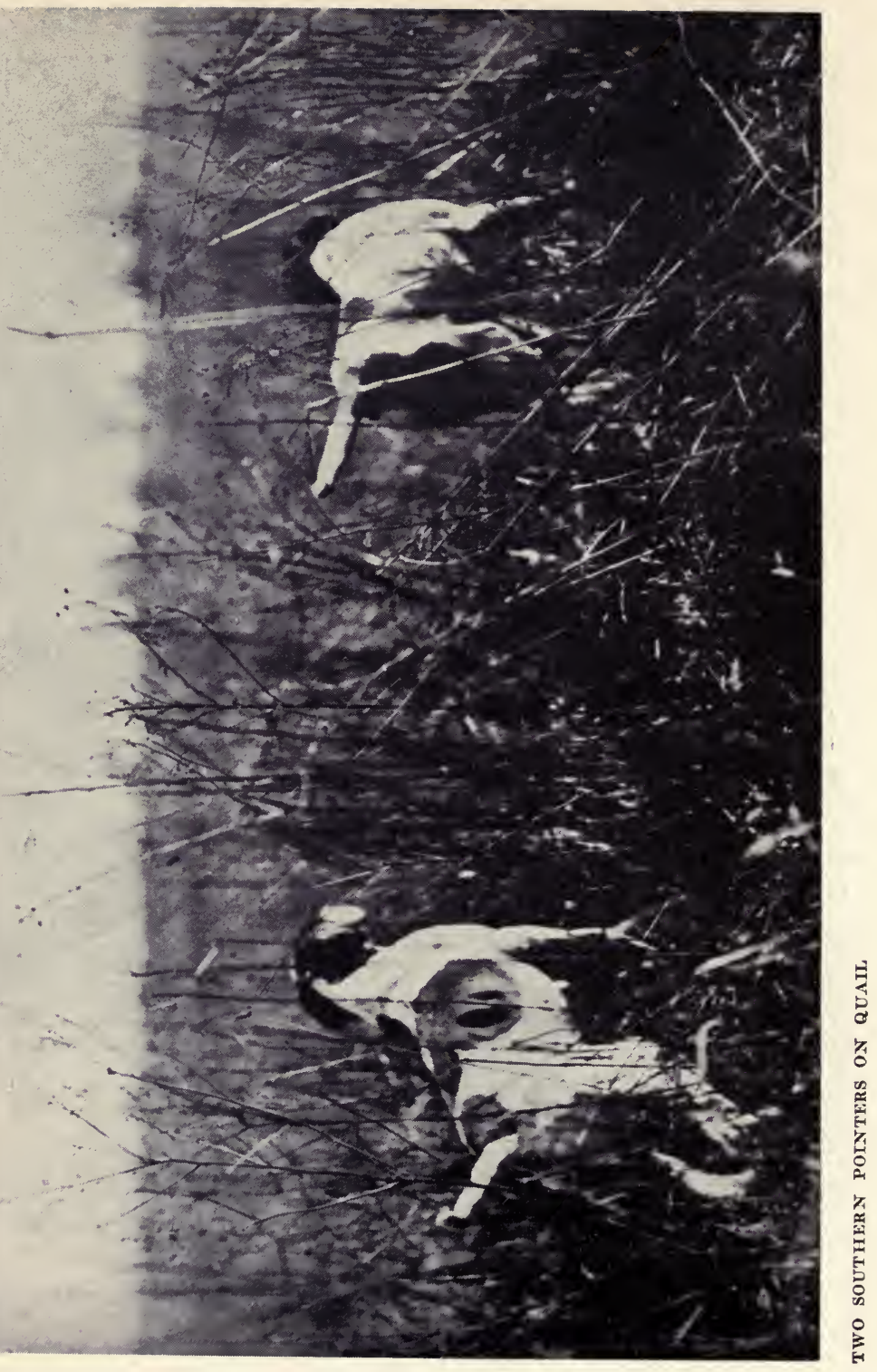


(Ch. Count Danstone (3490)

3 times a field trial winner in 3 starts and a sire of 17 winners.

(Blue Danstone (4210)

W on $2 \mathrm{nd}$ Alabama all age stakes 1902 , and 5 th Nebraska all age 1903,also many times bench winner.

Decatur Bell A great producer of many high class and noted shooting dogs, Dr. W. M. Beck of Clarkfield, Minn., her owner, says she is a perfect type, beautifully marked and has a wonderful nose. Says she "picks 'em up" after the other dogs have gone by.

Fairland Dot (6468)

A celebrated brood bitch who is the dam of many noted dogs.

Lady's Count Gladstone's Count(6511)

Bench wins include 3rd limit Hamilton 1906: 2nd field trial class Fort Wayne 1907; 3rd in Southern Ohio all age stake 1906 .
Ch. Count Gladstone IV Had 9 wins including the National Championship 1896, and a sire of 41 winners who won 89 times. He has a monument erected to him in California that cost about $\$ 800$.

Dan's Lady
Winner of 4 field trials Dan Gladstone and dam of 9 field trial and bench winners.

Lilly Burgess

Count Noble

One of the greatest setters ever imported. Sired 36 winners. Ruby's Girl
A producer of 6 who won 26 times. Sister to $\mathrm{Ch}$. Sue.

Ruby 11

Gladstone

Ch. Sue

Gath's Mark

Esther

Ch. Tony Boy (541)

13 times a field trial Ch. Antonio

winner and a sire of many winners. $\mathrm{He}$ was one of the greatest winners and producer of his day. You all know him.

\section{Lizzie Rhoades} A grand shooting bitch.

Little sister to the $\left\{\begin{array}{l}\text { Gath's Mark } \\ \text { Had } 4 \text { wins and a sire }\left\{\begin{array}{l}\text { Gath } \\ \text { Gem }\end{array}\right.\end{array}\right.$ noted winners "Al- of 17 winners.

lene," "MarksRuby," and dam of Dolly Manners and Jessie Perry and other well known dams.

Ruby's Girl

A producer of 6 Gladstone won 26 times. Sister to $\mathrm{Ch}$. Sue.

Ruby 11

Ch. Lady's Count Gladstone (1900)

Had 3 field trial wins including the National Championship 1900; a sire of 49 winners including the noted $\mathrm{Ch}$. Count Whitestone. His get has won 96 times at public trials and more to hear from.

Ch. Count Gladstone IV See above.

Ch. Count Nobl See above. Ruby's Girl See above.

Dan's Lady

See above.

Dan Gladstone Lilly Burgess

Ch. Rodfield (192) (Ch. Antonio Winner of 4 field See above. trials, and sire of the field trial winners "Oakley Hill," "Ortez Lad" and 36 other winners with 95 wins. Nellie Hope

Catherine Glynn

Kingston

Lucille's Nell

Foxy Warfield
A grand indi-
vidual and ex-
cellent brood
bitch.

Rod Warfield (3083)

Twice a field winner.

Ch. Rodfield (192) See above.

\section{Antonio \\ See above. Nellie Hope}

Louise Danstone (287)

(Ch.CountDanst (3490). See abc Marks Spot

Count Gladston See above.

High Land Bell (6198) Count Ladystone A great producer of high class shooting dogs.

\section{Dan's Lady} See above.

Nellie Noble (2551)
(Redfield (192)

See above.

Florence Gladet 


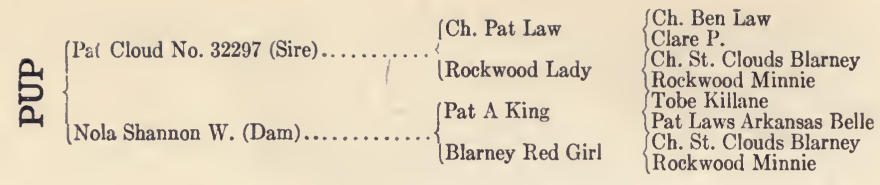

A WELL-BLOODED IRISH SETTER PEDIGREE

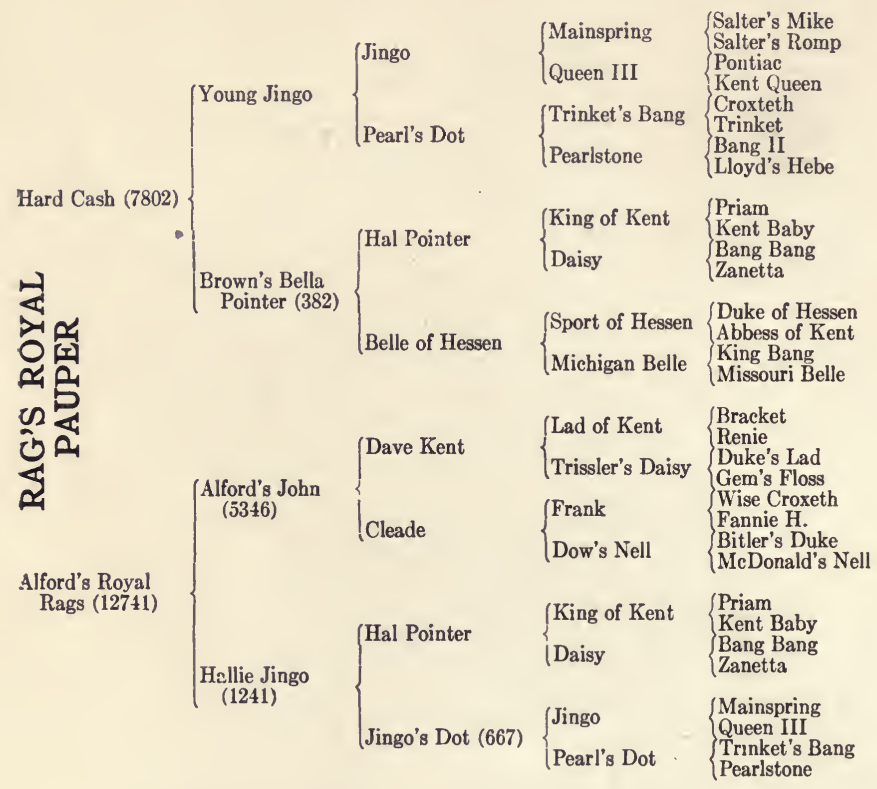

A TYPICAL ALFORD'S JOHN-HARD CASH POINTER PEDIGREE

The Llewellin Setter B O A Z No. 18045 F. D. S. B.

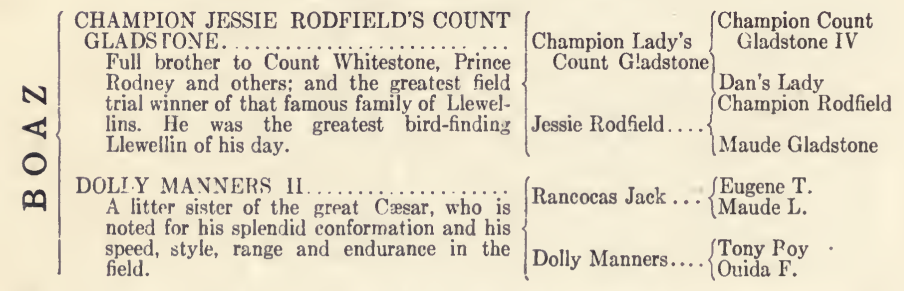

A PEDIGREE SHOWING THE CASAR-RANCOCAS JACK BRANCH OF THE LLEWELLINS 
Turning to the grouse dogs, at the New York State trials, first was won by Grouse Bo' (Victor Bo'-Lady Count Okaw), an orange belton Laverack; second by Crawford's Pennsylvania Tom (Sims Glenwood Boy-Lady Chippewa), a Llewellin-Laverack setter dog, and third by Dick, a Comanche Frank pointer. In the grouse stakes of the Pennsylvania field trials, Lamberton's Mack (Momoney-Susan Howard), a Llewellin setter, won first; Count Gladstone's Glad (Lady's Count Gladstone-Fairland Ruby), another Llewellin, won second; and third was divided between Ida Mae Whitestone (Babblebrook Joe-Lady Nancy Whitestone), a Mohawk-Count Whitestone dog, and Eugym Mohawk (Eugene M.-Wilson's Betty Whitestone), a Eugene M.-Mohawk blood blend.

Of course, in these great events you are bound to meet the champions of to-day, sons and daugh. ters of the champions of yesterday, again and again, as the same dog travels from one event to the next where the stakes are big, and earns much fame and money for his owner. The wins of a big champion may exceed $\$ 5,000$ in one season. But in the smaller state and local field trials, while you may not find the stars, you will find worthy 


\section{0 THE AMERICAN HUNTING DOG}

representatives of all the setter and pointer families we have discussed, most of whom entered the big events but were not good enough to win. But in their local fields these dogs are generally able to win over the general field, which in its turn is composed almost entirely of Gladstones, Mohawks, Whitestones, Eugene M.'s, Fishel's Franks, Raps, Hard Cashs, Alford's John dogs, etc., as the present-day setters and pointers might be described in general terms.

We cannot all afford championship dog fees, but there is no reason at all why a look-over of the winners of any of the dozens of lesser field trials scattered throughout the country should not give us choice of a dog having just the blood lines we want to blend with those of our own dog, and so universal is the distribution of the descendants of the dogs we have been describing that virtually no pointer or setter puppy alleged to be a Llewellin which does not show some of the heads of the family in his pedigree is worth bothering with, for pups of the true stock are reasonable in price and the performance of Derby winners of to-day shows the blood to be still potent and the best there is in the country. At the same time plenty of Laverack outcross is not to be feared, particularly in a dog 
for woodland shooting. Sir Roger, the Lingfields, the Alberts, the Queens, Mallwyds, Wellingtons, Uhlans, Ch. Deodora-these are Laverack names that mean good grouse dogs as well as great bench winners.

A glance at the Irish setters, for to my mind a renaissance of that noble breed is about due in our country. For your combined bird dog, saltwater retriever and hunting companion, handsome and easy to keep looking presentable, the Irishman is hard to beat. The owner of one of the best collections of Irish setters in the country is $\mathrm{Mr}$. Otto Pohl, and his ambition is to place one of them among our field trial winners. This kennel of eight dogs comprises all field hunters, free from the bench-show specialisation that has kept our Irish setters back during the last decade. This tendency to specialise has done the fancy lots of harm, as new sportsmen purchasers have been loath to buy Irish setter pups that may not own a hunting sire or dam for three generations back, preferring English that they know will be natural hunters, besides which the reputation for stubbornness that the Irish setter has accumulated also militates against him. And further, he is hard to see in the woods, which is the only real 


\section{THE AMERICAN HUNTING DOG}

detriment he has. Two Irish stocks come to mind, bred for field service through thick and thin, the Law and St. Cloud stocks, and puppies from them will be natural hunters, as their dams and sires were before them. Both stocks are well represented in the stud to-day, and plenty of pups are for sale, so there is nothing in the way of your owning a red setter if you want a dog for both ducks and upland shooting, no matter whether you live on salt water or in the prairie lake country.

A little history, for a starter, and then we can see where we stand with a pedigree such as your dog dealer will likely send you. While Signal and Blue Rock were the ancestors of many of the Irish setters in our country, the stock has been continuously enriched with fresh importations from the "ould counthry," Finglas coming over somewhat later, then Elcho, and of late Morty Oge. Mr. Pohl, one of the foremost fanciers of the Irish setter breed in the country, has recently imported two more dogs of the kennel name Rheola which seem bound to figure in future pedigrees, mingled with his Law and St. Cloud stock. Virtually all the above dogs were champions in their day. Ch. St. Cloud III, the greatest of the St. Cloud stock, 


\section{WHO'S WHO IN BIRD DOGS 53}

is a blend of Signal and Elcho, being by Connaught ex Reddie. Connaught is Kildare-Bessie Glencho, and Reddie, Babe Elcho-Queen S. A typical Elcho dog is Nell Elcho, Fred Elcho (Duke Elcho-Red Rose), ex Red Bess (Finglas-Red Nell), which gives you an idea of the blood lines. The Culbertson Irish setters, of which many representatives figure in present-day pedigrees, may be sketched in by the pedigree of Alan of Culbertson, who was by Shamrock Signal (Signal-Flossie Finglas) out of Lady Pat (Patencho-Blue Rock's Maid). Of the Law stock Ch. Pat Law is Ch. Ben Law-Claire P. A present-day stud dog is St. Cloud's Kenmore (Ch. Heir at Law-Daisy Law), while Ch. Conn-Law is the head of the family, defeating the best imported dogs of late years. They all get their peculiar kennel suffix from old Shan Law of Ireland. Mortys Lad, a present-day blend of Law and Morty Oge blood, is Shan Law via his dam Glenariff Patsy, a daughter of Glenariff Chieftain and Shan's Fannie. Ch. Conn-Law is by $\mathrm{Ch}$. Ben Law ex Elcho Bess, which places him accurately enough. Most pup pedigrees that one examines for blood lines to-day contain a good deal of Law, St. "Cloud and Morty Oge blood, with perhaps a dash of Rockwood or Culbertson 
54 THE AMERICAN HUNTING DOG appearing in dam or sire somewhere in the pedigree, and any pup with such blood in him is an Irishman bred in the purple which will do to train. 


\section{CHAPTER III}

WHO'S WHO IN HOUND DOGS

American hunters are principally interested in three big divisions of hounds-coonhounds, foxhounds and beagles. They constitute three-quarters of all the hunting dogs used in the United States. Of the three kinds, the coonhound is distinctively American, the foxhound Americanised, and the beagle almost unchanged from the fixed English type. The coonhound is distinctly our dog. Used for deer, coons, bear, wild cat and all kinds of treeing "varmints," he has had as much to do with the development of our country as the pioneer himself. He was the pioneer's dog in fact, and for the last three centuries has been the hunter's dog all over the backwoods. In the old days we had to take our meat as we found it, running wild in the forests, for butchers and beeves were not and the English grenadiers that we used to kill for winter meat got scarce after '76. The coonhound started with innumerable hounds brought over by the settlers-French, English and 
Spanish strains all being well represented-and from a mixture of them, through a century of training and breeding to high-class performers only, came the American coonhound. The French hound is more like him than any other recognisable breed to-day; long-eared, rat-tailed, powerful, gifted with an unequalled nose, he became the well-known "potlicker" or "smell dog" of the South, while the New England and New York hounds, used mostly for deer and fast fur, developed into famous fox-hunting strains, of which the Buckfield, Portsmouth and Pennsylvania are representative. A good deal of foxhound was crossed in on these latter to give more speed, the Irish hounds of Maryland being used extensively for that purpose, for these were then the best of the old grey foxhounds of the South. In those days hunting the grey fox was the principal sport of the Southern gentry, and from Maryland to Tennessee every wealthy planter had his pack of grey fox dogs. Washington's favourite entry in his diary, after retirement to Mount Vernon, was "Ketched a fox to-day"-or two of them if the luck was good! The grey fox was a slow little beast and the long-eared hound was plenty fleet enough. With the introduction of the red fox from England and the North, all this was changed, 


\section{WHO'S WHO IN HOUND DOGS $\mathbf{5 7}_{\mathrm{i}}$}

as "red" could outrun and simply play with these old-time foxhounds, so new blood was imported from England, and the American foxhound as we know him to-day began to develop. Meanwhile, the coonhound went his own ways. His job was different, slow cold trailing, running deer and the like, which called for breeding from great performers regardless of colour or family strains, so that the coonhound is not a matter of big names but rather of good strains in his selection for purchasing.

Davy Crockett, that king of bear and coon hunters, had one of the best packs of the old Southern coonhound, and, as he gave great numbers of puppies away to political friends, lots of descendants of his dogs are extant to-day. His example was simply an instance of what was going on all over the country, noted hunters giving or selling puppies from their own packs of trained dogs, no stud books being kept, and the result has been an absence of anything like papers of pedigrees among the coonhounds on sale to-day. That the pup comes of a noted hunting ancestry is about all one has to go on. Two strains are well known, the Redbone, an ancient breed of Southern coonhound, and the J. E. Williams dogs. Williams ran a kennel of his own up to about 1911 and kept a 
large pack for his own use, as coon hunting was his favourite recreation. The Redbones, more or less pure, or else crossed on Walker stock, are in existence to-day and still going strong, quite a few kennels advertising them.

Of the Northern hounds, the Buckfields originated around the town of Buckfield, Me., and were used for deer driving and fox hunting in the Northern style, that is, the gunner standing on a runway and shooting the fox ahead of the hounds, just as deer are shot in the South. An aside here seems inevitable on the oddities of sectional notions regarding the ethics of sport. Your Northern still-hunter of deer looks with as much horror on the driver of the South as the horse-and-hound man of Kentucky does on the New Englander who would dare to shoot a fox instead of running him to a finish. Really, it is local conditions that govern in both cases, and the ethics are equally sportsmanlike in both. It would be impossible to run a fox with hounds in the Northern mountains; also impossible to still-hunt a deer in the Southern brushwood. You must have more or less open country to run foxes to horse, and you must have mountainous country to still-hunt deer. The best horse could not keep up with a fox in the Vermont hills, so they are shot ahead of the dogs; 
WHO'S WHO IN HOUND DOGS 59

no man can see a deer thirty yards in the Southern brush, and so dogs must be used to drive them past stands where one can see to shoot. That is all there is to it, and there is no cause for the hunters of one section to despise those of the other.

Getting back to the Northern deer and coonhounds. The Buckfield strain seems to have originated from a regular old-fashioned trailer dog, Tige, and a fast bitch, Skip, a coarse-haired foxhound, and therefore, probably one of the Plummer or Sugar Loafs which were coarse-haired and brindled in colour. One of the puppies of this mating was the famous Gledhill bitch, who proved a wonderful fox hunter, of endless staying qualities and able to work the fox in all kinds of weather. She was bred extensively and is the dam of the Buckfield strain. Among her progeny are Dime Buck, Dime Dansforth, Red Dime, Red Sport and Tomey. The most famous hound of the strain was Jim Blaine, out of the Buckfield bitch, Pert, by a full-blooded Byron hound, of which strain more later. As a rule the Buckfields are coarse-coated dogs, red or tan, or red and blue mottled, with now and then a black one, a throwback to old Tige, who was solid black.

Of the old Redbones but little is known except 


\section{THE AMERICAN HUNTING DOG}

that they were one of the most prominent "native" southern hound strains, true representatives of the pioneer's coon and deer hound. No names are available, but there are a number of kennels in the South to-day which breed them more or less pure, and the quality seems as good as ever. The ones we have seen were all large, bony, black and $\tan$ hounds, with long ears. Of the J. E. Williams hounds more is known. Neely was one of his best bitches, a black and white dog, lightly ticked, large and rangy. Other good ones in his pack were Bigun, Dan, Guard, Ruler, Queen, Deliah and Old Tom, and, as the stock is widely dispersed in the southern and central States and shows up well in the hunting qualities of pups of that blood, it is highly prized by the trapping and night-hunting fraternity. The Pennsylvania hounds are a blend of the old native long-eared Virginia hounds, and the smaller and faster Maryland hounds with much more foxhound blood in them. They are principally used for coon and snowshoe rabbit hunting, and are found all through the mountainous parts of the State, particularly in the southern portion.

When we come to the foxhound a mass of history and stud book records confronts us, and the going is much easier. The American foxhound 
began with the introduction of the red fox into the South. Before that the little grey fox afforded all the riding and was easily trailed by the native pioneer's hound. It seemed incredible to the gentry of that period that the red fox could easily lose their best dogs, and some red foxes had to be imported from England to prove it. Followed then importations of regular English foxhounds, which were crossed on our native bitches to give more speed to their progeny. The oldest and best known strain was the Brooke, brought over from England by Sir Roger Brooke, who came over with Lord Baltimore and settled in Maryland. In $1822 \mathrm{Mr}$. Bolton Jackson imported Mountain and Muse from Ireland and we get most of our foxhound strains from these and the Brooke dogs, which were extensively crossed. In 1738 a pair of red foxes was brought over by the captain of the tobacco boat Monocacy, and it was their advent into Maryland and the subsequent showing up of our native hounds as too slow that was the direct cause of this importation. The two dogs Mountain and Muse became the property of Governor Ogle, and their get was bred extensively on the native stock of the fox-hunting gentry of Maryland.

une of these hunters, Mr. Gosnell, bred and 
presented to Mr. Miles Harris, of Georgia, a pair of pups, one of which was the dog July. $\mathrm{He}$ proved a sensation as compared to the native hounds of the central South, and so became very famous and was bred to extensively, establishing what is known as the July strain of Georgia foxhounds.

The next famous strain was the Trigg, owned by H. C. Trigg, noted southern hunter. Originally the family owned a pack of the fine old rat-tailed, long-eared, deep-toned Virginia black-and-tan foxhounds, but the advent of the red fox into Kentucky changed all that, and the Triggs had to assemble a new pack. The stock was obtained from Mr. Birdsong in Georgia in 1867. He had then in his pack the famous dog July, and also his Henry dog Longstreet. From him he bought Chase and Bee (by Longstreet), George, Rip and Fannie, paying $\$ 400$ for the lot. From General Maupin he bought Minnie, a descendant of the noted dog, Tennessee Lead, and from Colonel Walker he got the dog Mattie. The Trigg strain is thus seen to be a blend of the Birdsong, Maupin and Walker stocks.

Following out this line of foxhound history, we first see the connection of the Triggs with the original Maryland stock through July, and next 


\section{WHO'S WHO IN HOUND DOGS 63}

in logical order would be the Birdsong dogs. These dogs were developed by Mr. Birdsong frorn a pack of notable Virginia foxhounds owned by Dr. T. Y. Henry. These were all Mountain-Muse dogs from the Irish Maryland strain, and were used by Dr. Henry principally in deer hunting. Mr. Birdsong then bought the dog July and crossed him on these Henry hounds. Longstreet and Hodo were part of the original Henry pack, and so we get the main outlines of the Birdsong strain.

Coming now to the Walkers, these were also old-style grey fox dogs originally, and, with the advent of the red fox, showed the same lack of the needful speed. As Mr. Walker, senior, was a close friend and county neighbour of General Maupin, the first outcross was to Maupin's Tennessee Lead. This dog was a stray, picked up running a deer, but was evidently a foxhound of English or Irish descent, very fast and yet having a trailing nose, and he improved the Walker strain immensely. Aside from the importation of Striver and two bitches from England some time later, the Walker strain was kept intact, simply adhering to careful breeding from the best of the Tennessee Lead-Walker pups.

This covers the principal American foxhound 
families, with the exception of the Byron strain. About 1850 a club of foxhunters in Petersburg, Pa., imported the English bitch, Clio, to breed her to the famous Maryland dog, Rattler. The mating resulted in four notable puppies, Byron, Music, Rattler II and Dido. Byron went to Colonel Tucker, Rattler II was retained by Colo. nel Starke (the owner of Clio), Music went to Colonel Hampton, of South Carolina, and Dido went West, where her blood is found in all the best known Kentucky and Tennessee strains. Byron became very famous and was bred to by the owners of foxhound packs, his name being given to the strain of foxhounds thus sired by him.

Into other noted strains, such as the Arkansas Traveller, Wild Goose, Robertson, Whitlock, Avent, Cook, etc., it is not necessary to go further here than to generalise that each was founded by some noted dog, bred on original native stock, the blood of the Maryland, Walker and Birdsong (or July) strains being prevalent in all of them. The Williams strain of to-day was developed in the same way from Walker-Maupin stock, improved by the judicious addition of imported English blood, by General Roger D. Williams, of Kentucky. Of his champion dogs we may note Scrape, Jip Sharpe, Barney, Scorch, Lee, etc. My 


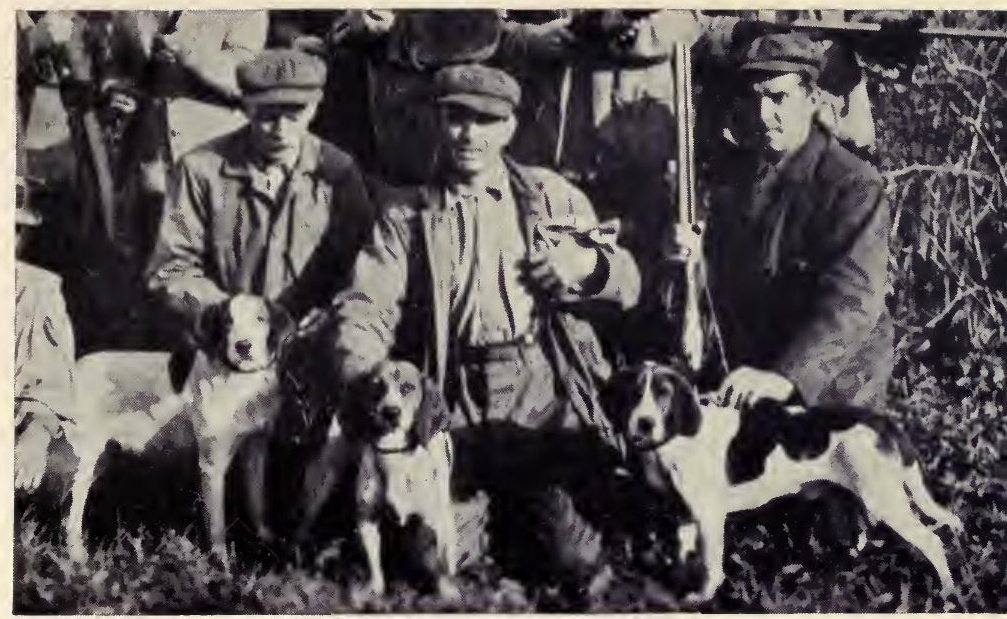

TYPICAL RABBIT BEAGLES-OUT FOR A DAY'S HUN'T

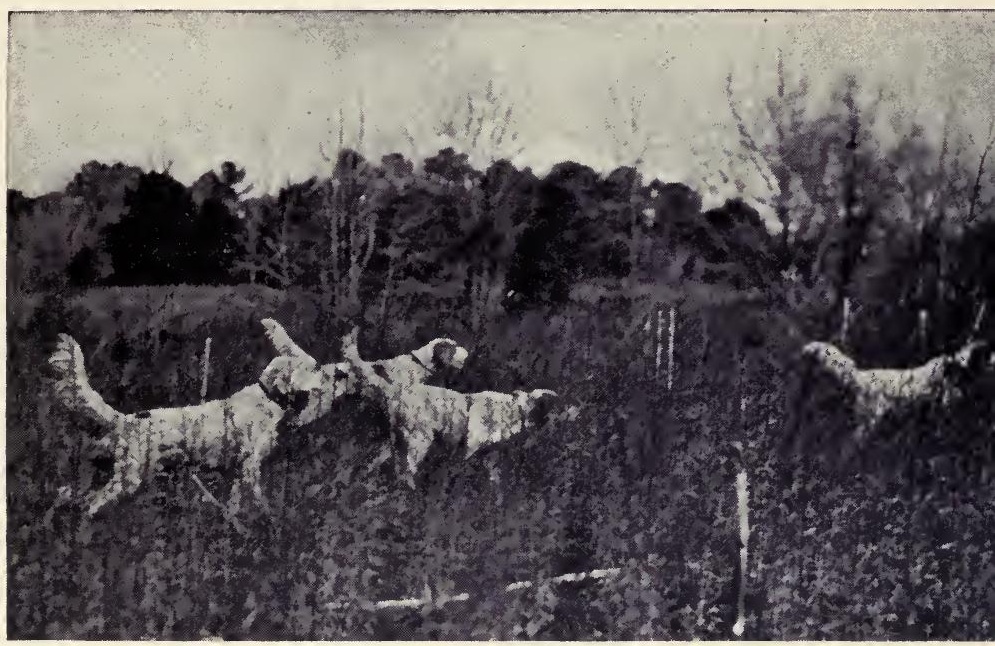

FOUR CRACK LLEWELLINS-ODESSA (POINTING),

LANARK LAD, GYPSY NOBLE AND TONOPAUGH 


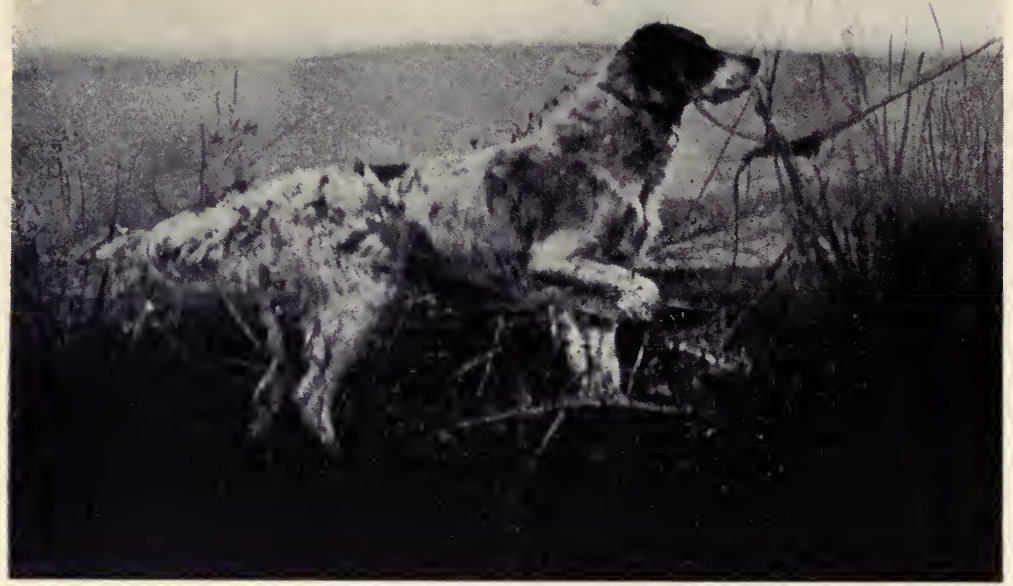

MOMONEY II, A CRACK FIELD TRIAL SETTER

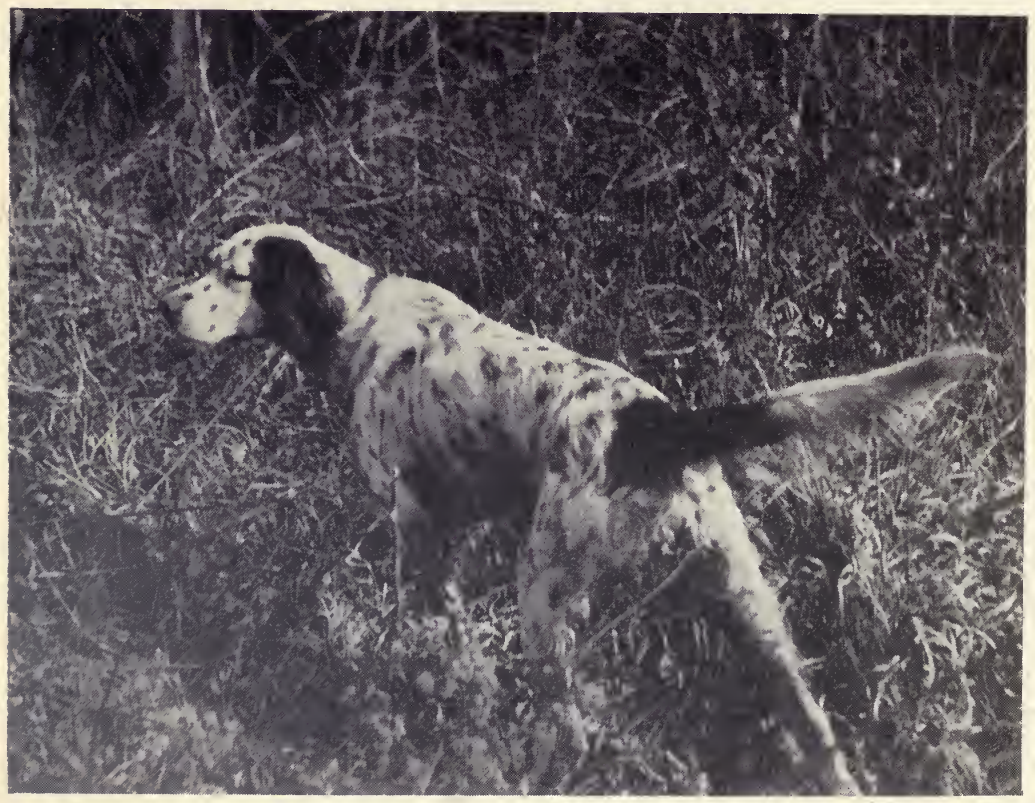




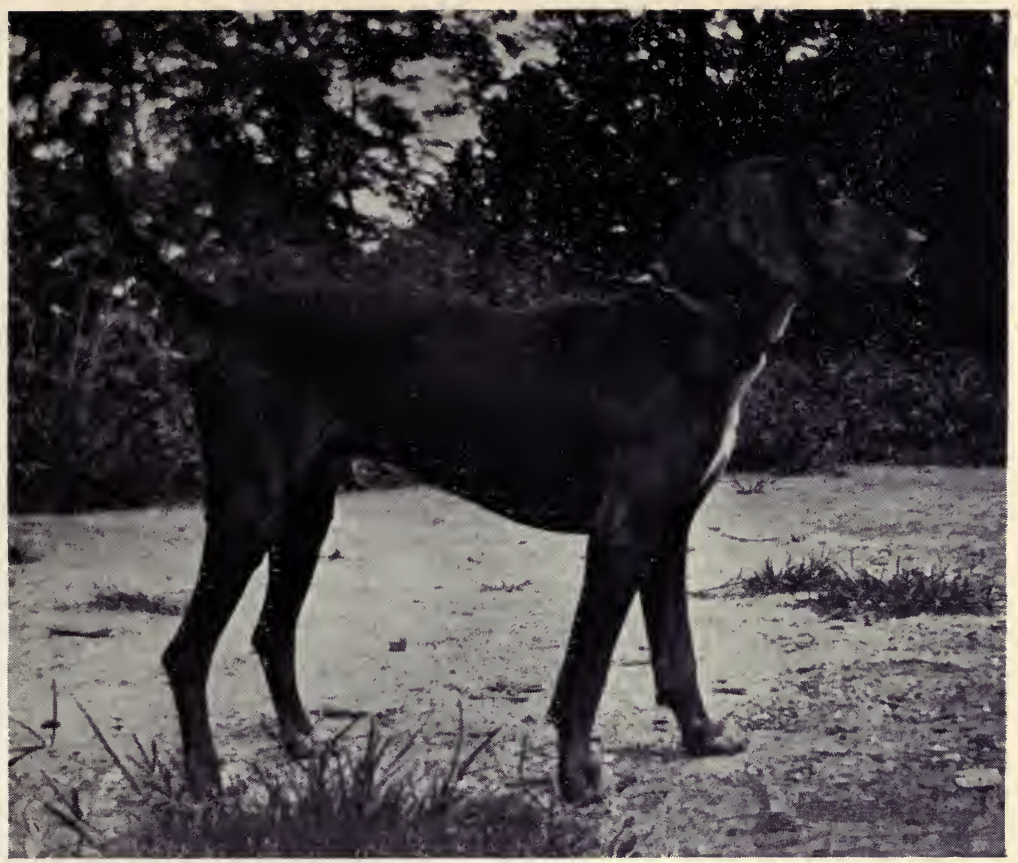

TYPICAL TENNESSEF REDBONE COON HOUND

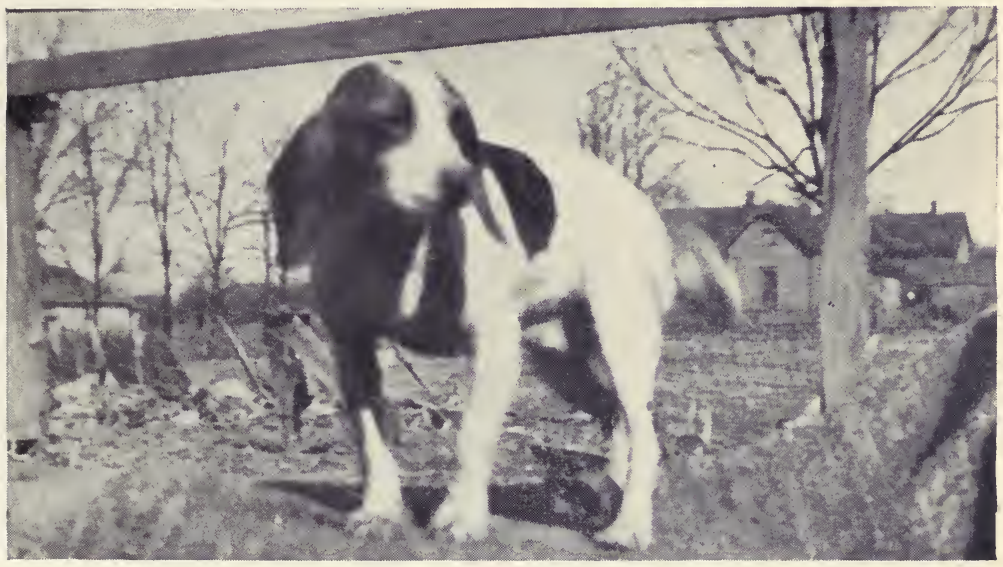




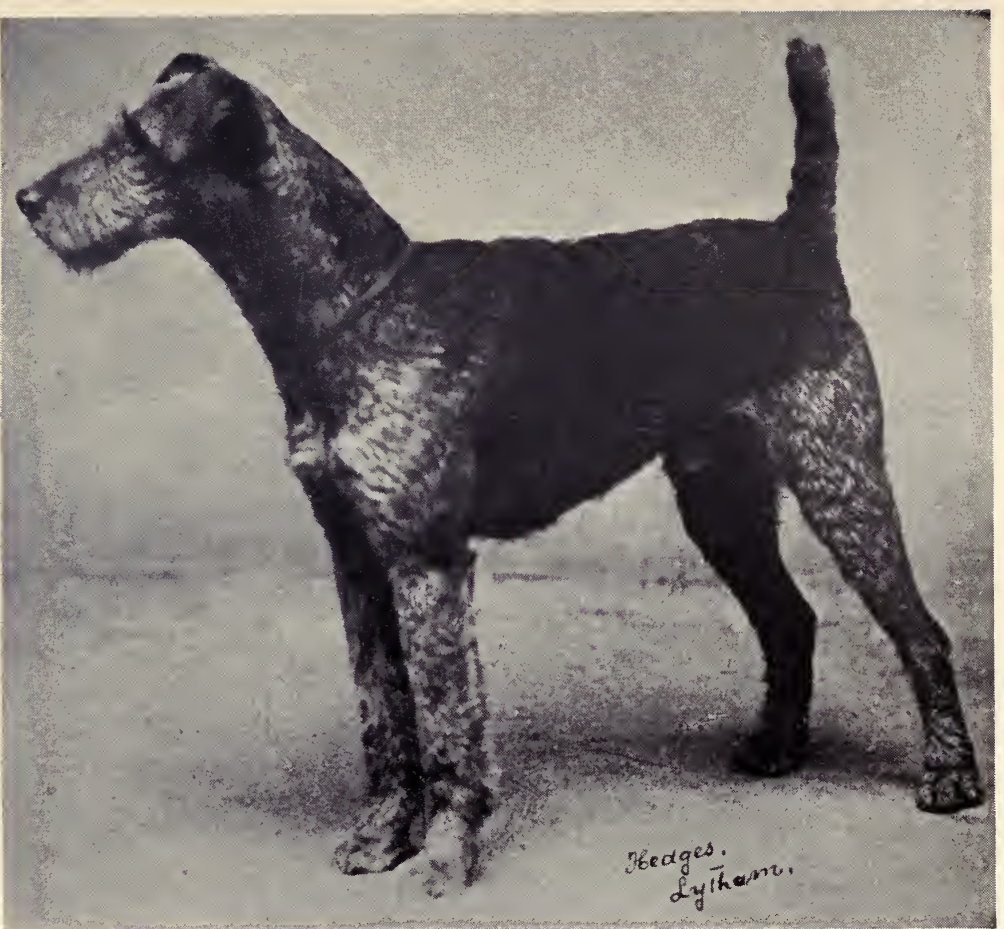

(Courtesy Forest \& Stream)

AIREDALE TERRIER, CH. ILLUMINATOR

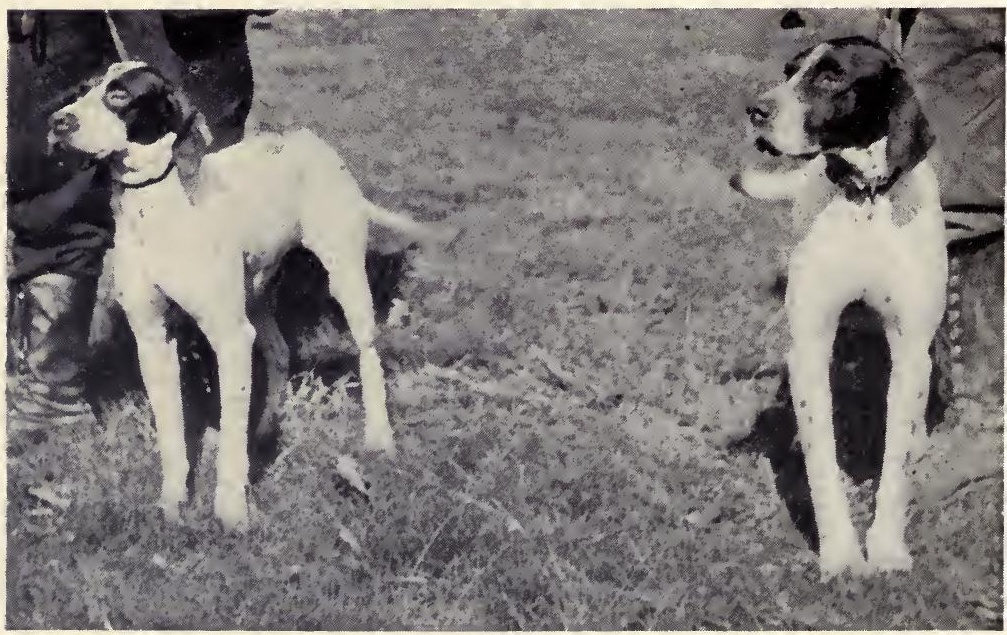

THE CHAMPION POINTERS, "MANITOBA RAP" AND "ALFORD'S JOIHN" 
WHO'S WHO IN HOUND DOGS 65 own dog, Pepper, is by Lee out of Wake, and has won so many ribbons that he is by now a champion himself no doubt. He was carrying everything before him in both bench and field trials when last heard from, and is now the property of the Rookwood Kennels of Lexington, Ky.

The popular and ubiquitous beagle, rich man's and poor man's dog alike, is very plentiful in our country. We have three kinds, the standard 15inch, the pocket variety about nine inches at the shoulder, and the large beagle which takes after the harrier and stands over twenty inches, making a good dog for fast snowshoe hare, and good also on plain Molly Cotton-tail. Our first standard beagles were General Rowett's pack, imported from England, though of just what strain there is no record. The dogs of this pack that have had much influence on beagle breeding in America were Warrior, Rosey, Sam and Dolly, who enter into the blood of many of the best beagle strains in America. Rattler was of the mating WarriorRosey, and was extensively bred to. Ch. Frank Forrest was the most famous of the New England beagles, and achieved the double championship of both bench and field. Ch. Lee and his son, Bowman, were also noted beagles of the early nineties. Imp. Bellman, mated to another Rowett 
beagle, produced Dan D., winner of the 1902 field trials. In general the Rowetts were cobby blackwhite-and-tans, heavy boned, with long heads, and they run so true to type that any dog with Rowett blood in him will make a good showing at either field or bench trials.

Of the smaller beagles, Ch. Bannerman heads the list, a nine-inch beagle, brought over to counteract the American tendency to large size. He was the chief rival of Frank Forrest at that time. Frank Forrest, mated to the imported field bitch Sue Forrest, of the Elmore strain, produced $\mathrm{Ch}$. Clyde, Sunday and Gypsy Forrest. These all produced noted field trial dogs, and Clyde's son, Trick, made it three straight generations of Forrest field champions beginning with Frank Forrest. Comeroe, of the Elmore strain, was by imported $\mathrm{Ch}$. Ringwood, and the strain was crossed on the Rowetts with fine results for both field and bench qualities. Imp. Chimer and Myrtle were brought to Pennsylvania and started another line of beagles which were crossed on the Rowetts and on the combination of Rowett and Elmore, the best dog of the line being Lady Novice; also by Chimer and a Rowett bitch we got Spinaway. Two of her sons, Robino II and Fashion, became 


\section{WHO'S WHO IN HOUND DOGS 67}

leaders in 1902. The small dogs, Bannerman and Blue Cap, developed great steadfastness in rabbit tracking in their get, and the nick was used by many of our present day breeders. 


\section{CHAPTER IV}

SPEOIAL FIELD DOGS

ANother breed not to be overlooked by American sportsmen is the French pointing Griffon. In 1916, for the first time, one of them ran in one of the great field trials and gave such good account of himself that one of the best Llewellins had to stretch himself to make good against him.

This Griffon, Homere's Jack, was run in the National Capitol Field Trials. He drew a crack Eugene M.-Gleam dog, Tip Top Merry Boy (Mike M.-Gleam's Belle). Every one was anxious to see how the Griffon would make out in comparison with a crack Llewellin. The Frenchman did very well, for, while Merry Boy was full of class and had plenty of speed, the Griffon was right after him. Unfortunately no birds were found during the heat, so the trial was quite inconclusive. Homere's Jack is by Homere-Fileuse de Merlimont, a steel-gray pointing Griffon. I have noted these dogs carefully at bench shows and know them from puppyhood up. The logical-minded 


\section{SPECIAL FIELD DOGS}

French claim that their sporting dog is the best all-around field dog in the world, since he is as good a pointer and bird-finder as he is a retriever (and we all know how lots of the finding of grassed birds is often left to us by our crack pointers and setters), and his double coat makes him impervious to cold in swimming after ducks. It will probably take several generations of American breeding to develop in the French dog the combined speed and nose required of a field trial winner, but the fancy in this country is in good hands, notably Mr. L. A. Thebaud. The Griffon is not a handsome dog, compared to either pointer or setter. His head is heavy and square-lined, his coat is wire-haired and grey with black spots, and in general he looks like a cross between the Airedale and a blue belton setter. His tail is always docked for the same reason in looks that a terrier's tail is docked. The wire-haired coat is, like that of the Airedale, double, with a vest of fine downy hair underneath, making the dog able to plunge into icy water after ducks. like a Chesapeake, and enabling him to withstand the rough going in briers and wet underbrush that would soon put either setter or pointer to shivering and flinching. Mr. Thebaud, who spent much of his time in France hunting with the 


\section{THE AMERICAN HUNTING DOG}

French-American painter, Rosseau, became much impressed with the possibilities of the Griffon as the dog in our country to solve the problem of a good all-around dog on both upland game and wild fowl. There is no question that the Griffon both points and retrieves under unusual conditions, both of which the Chesapeake cannot do, and for an all-around sportsman who can afford but one dog the Griffon should claim very serious consideration.

The family began in our country with Kob de Merlimont, imported by Mr. Thebaud, to whom were later added Homere and Fileuse de Merlimont, parents of the 1916 entry, Homere's Jack. Of the German strain of Griffons we have Bolero von Gimbsheim, Korthals and Passe-Partout. There are but few Griffons advertised for sale. Mr. G. Van Morgan, of Denton, N. C., maintains a kennel of Griffons, and Mr. Thebaud, of Morristown, N. J., will occasionally part with a dog to one who is sincerely interested in advancing the name and fame of the Griffon in America.

Dr. Ilyus, of Lancaster, Pa., not only has Griffon puppies for sale, but offers two good ones at stud, Flambeau Planig (Le Capitaine Fracasse ex Anna Planig), a German Griffon, and Bolero von 
Gimbsheim, noted above, by Ch. Rabot ex Diana von Gimbsheim.

When it comes to an out-and-out retriever our own Chesapeake Bay dog is one of the best. This fancy is already well established, and good pups are to be had at reasonable prices. For the duck hunter, pointing and bird-finding ability are not the requisites for his furry hunting companion. Rather, he wants a big strong dog, able to swim in rough seaways in both salt and fresh water, double-coated so as to be coldproof in duck weather, and of perseverance and hardihood sufficient to sustain a long chase after a crippled duck. These the Chesapeake has to perfection. He lies in the blind quietly, makes no sound while the ducks are coming in, and when the guns are through his part begins, which is to jump into the icy water, swim out and catch any cripple and afterward bring in the slain. Owing to the ease with which ducks note the smallest black object, the ideal coat for the Chesapeake is a sedge brown.

There is no need here to go into the various stories concerning the ancestry of the Chesapeake; suffice it that the breed has been well established for some forty years, and was in its zenith during the great days of the ducks on the 


\section{THE AMERICAN HUNTING DOG}

Chesapeake, now gone forever. Among presentday sires the get of Beaver III appear both in the stud and puppy pedigrees offered on the dog mart. Clark's Sea Wolf and Clark's Sea Tramp are typical Chesapeakes, both by Beaver's Rex out of Edmund's Lusitania and Finey's Pride, respectively. Other good puppies offered are by Water King ex Bessie H. Mr. Pulitzer's Brownie was the star bench show Chesapeake of 1916.

Going further back into the Chesapeake hierarchy, we soon get to Ch. Chester (BrowniePride), the finest of the breed. Chester Matthews, a present-day dog, is Hale's Dick-Juda, in the direct Chester line, while Furlike, another good one, is Ferg's Bingo ex Juda of the ChesterMollie Evans strain. A typical three-generation Chesapeake pedigree would be as foilows:

Clark's Sea Wolf $\begin{cases}\text { Beaver's Rex } & \begin{array}{l}\text { Beaver III } \\ \text { Dan's Otter Girl }\end{array} \\ \text { Edmund's } & \text { Water King } \\ \text { Lusitania } & \text { Dolly J. }\end{cases}$

THREE GENERATIONS OF CHESAPEAKE LINEAGE

which should give the reader a fair idea of the family lines. It is quite as essential to get a purebred Chesapeake as a pure-bred setter or pointer, for crosses and mongrels never can specialise like thoroughbreds. Nerve and stamina are what are wanted in your Chesapeake, a dog that will crash through thin ice, cutting his own channel after a 


\section{SPECIAL FIELD DOGS}

duck, and have grit enough to do it again and again. Here's where the yellow streak will show out, if a mongrel. That, and looks. For the thoroughbred is a good-looking dog, whatever rags-and-tatters cross-breds may masquerade under the name Chesapeake.

The great rival of the Chesapeake is the Irish water spaniel. An odd-looking dog, but every one who has ever owned one swears by him as the greatest ever. Mr. Percy Swan, of Chico, Cal., has lately imported a number of good ones and Dr. H. E. Rodley, of the same place, has a fine lot. His Ch. Hooker Oak Hogan is a typical dog of the breed. Hooker Oak Harp, Imp. Florrie McCarthy and Lady McShane will be names frequently met with in American strain Irish water spaniel families. The best colour is a reddish brown almost as sedgy as Chesapeakes. The Rev. T. Moore Smith is one of the best known breeders of the fancy in the east. As to some of the wonderful feats of endurance and staying qualities in icy water and freezing duck weather that these dogs accomplish as part of their day's work the California duck hunters are only too eager to testify. I have read many an enthusiastic letter from owners of the breed who hunted their dogs day after day in such conditions. 


\section{THE AMERICAN HUNTING DOG}

While the English Retriever has but small vogue in our country, there being but one entry in the big 5-point Westminster show, any breed that has some special virtue will always find adherents among our sportsmen. The Retriever has been in the main supplanted by our own Ohesapeake, and the Irish Water Spaniel, but there is another dog, called, Down East, the Tolling Dog, which hails from Newfoundland and seems destined to have a future with us. His admirers have written me at length concerning the virtues of the breed. I shall content myself here with a brief statement of the particular claims of the breed on the attentions of American sportsmen. Suppose you had a dog that bred true to type, was an unexcelled cold-water retriever and would "toll" ducks for you. Sounds interesting, but just what is "tolling" ducks! Well, Down East they have solved that vexatious problem of a raft of ducks playing out in front of your blind (but most warily keeping well out of gun range), by using a tolling dog. This dog is trained to perform antics in the sedge; now in sight, now down in the grass, appearing and disappearing, until the curious ducks begin to swim in, little by little, to satisfy themselves what it is all about. They seem to have no fear of the toller which is a rather small dog, and soon are in 


\section{SPECIAL FIELD DOGS}

range, when the gunners up and at 'em, whereupon the toller swims out, retrieves the slain, and again begins his tactics when another flock settles out in front. By this means a good bag is secured under adverse circumstances familiar to us all, those aggravating days when the ducks will not trade but persist in rafting out in the bay considerably out of range.

Such is the toller, seemingly a breed produced by crossing the English retriever on the wellknown Labrador dog or Labrador retriever, a close relative of the Newfoundland. Mr. H. A. P. Smith of Nova Scotia is at present the principal breeder of these dogs.

A final field dog is the much neglected spaniel. In England he takes the place of the setter here, for the average poor man's dog. Easy to keep, affectionate, a good bird-finder, the spaniel is just the dog for the close English coverts, where you want the ground thoroughly worked up. I should say that he fills a good niche here, for the suburbanite sportsman's dog. Suppose you want a house and watch dog that you can train to retrieve and that will naturally point grouse, woodcock and jack snipe when you get a day off and set out in the car to get a little shooting. A good, quiet, brainy cocker, working near you yet marking for 


\section{THE AMERICAN HUNTING DOG}

you just where Mr. Pat is hiding so you will not be looking somewhere else when he jumps, will do all for you that setter or pointer can do, and will be a much easier dog to keep. Again, suppose the hill country in your neighbourhood has many an oozy rill where the flight birds of the Canada woodcock pitch down and stick around awhile during the fall months. What better dog for an occasional day with them than a little cocker, which you can whistle up any time about the house and don't have to keep in a kennel? Or, if you live down in the prairie and woods country of the central states and get a day in the marshes after jacksnipe or a day's ducking, again the cocker is as good as any dog, and is a grand water retriever if the water is not too icy. Yes, sir; there's a lot that that diminutive setter, the spaniel, can do for you, and most bird-dog laws and restrictions pass over his head, as in our country he is hardly classed by wardens as a hunting dog at all.

This disqualification as a hunting dog is due to the bench-show evil, which operates to produce point winners rather than gun dogs. For the sportsman a line of the spaniels that are being worked afield is of more value than all the famous bench names in the world, so there is not much of value in going into spaniel history, as we have 


\section{SPECIAL FIELD DOGS}

with field trial setters and pointers: The Watnong spaniels, a kennel maintained by Mr. Wilmerding, of New York, is a good example of real field dogs kept so by continuous working. His Ch. Matterhorn, or the Watnong bitches, Floss, Irene and Nettie, give good hunting spaniel parentage. The Canadian dogs, Ch. Black Duke, Black Knight, etc., and the dogs from the Wealdstone, Saybrook and Brookside kennels, are all field spaniels that have not forgotten how to hunt.

For cockers, i.e., woodcock spaniels, the Midkiff, Lucknow and Bellevue kennels are reliable, but breed mostly for bench show points.

On the borderland between the bird dogs and the fur dogs stands the Airedale, the dog who can hunt both. What shall I say of him-I who know and love him so well? My opinion of him remains about as it was when I penned "Airedale, Setter and Hound"-as just dog he is unbeatable, but as a specialist on either fur or feathers he is not to be compared to the breeds which were old in the hunting game centuries before the Airedale was ever thought of. He is the greatest of the terriers, and the one who can and is being successfully trained to hunt everything alive that can be hunted. Tackling bear or cougar, routing out woodchucks, jumping rabbits, tree marking squir- 


\section{THE AMERICAN HUNTING DOG}

rels, pointing grouse and quail, running pheasants, and retrieving any and all of them-the Airedale properly trained has done all these things in hundreds and hundreds of individual instances.

As staunch and dependable a friend as one can ever have, the Airedale is essentially a man's dog - a manly dog, if I may put it that way. There is something essentially feminine about a setter, with his endearing ways and graceful form; and there is something essentially wild about a hound that we humans never quite get to the bottom of ; but your Airedale you can know as man to man. You feel as if talking to another man, and a true and tried one, when you talk to him, and there is no small deed of courage and stout-heartedness that you may not attempt with him along as partner.

While they breed pretty true to type, there is a good deal in the fortunate selection of the individual Airedale. The bench shows are full of champs, who have been bred exclusively for points, with never a thought to the dog as a hunter, so that the name of the Airedale winner of the moment on your pup's pedigree is no guarantee that he will develop into a good hunter. Some of the best of them possess brains, as well as points in sumptuous profusion and given a good brainy dog you 


\section{SPECIAL FIELD DOGS}

can teach him the whole hunting game, for even the gun dogs proper do not inherit much more than a good nose and hunting instincts and also need special training. Wherefore your first care is that the Airedale sire and dam are notably smart dogs, preferably with a hunting education. There is no great hierarchy of dog families to guide one, as there is with the Llewellin setters, for every year sees several new imported champions which sweep all before them and start new Airedale families of their own. One year it will be Ch. York Ryburn Swell, the next show he may win reserve while Tintern Top Hole or Abbey King Nobbler takes first. Ch. Soudan Swiveller comes the nearest of them to being both a crack bench dog and a crack hunter. But there are a number of big kennels breeding extensively in hunting Airedale stock, and their kennel suffix goes along with the pup's given name, and these aid one somewhat in placing the dog as a hunting possibility. Such names as the Oorang, Vibert, Culbertson, Ozone, Cedarview, Oaklawn, etc., kennels are a guarantee that your pup has many a hunting relative among his forebears and has a fair start anyhow. The rest is natural adaptability and training. If you don't train your Airedale as thoroughly as you do your setter you cannot ex. 


\section{THE AMERICAN HUNTING DOG}

pect equal results. But any number of sportsmen have succeeded beyond all statements yet in print in the extent and variety of hunting accomplishments which they have taught their Airedale to master. The thing to do is to get out and hunt with him and let him learn by experience. Let him dig out his own woodchucks, 'possums, muskrats; hole up his own skunks and squirrels; your part being to guide the hunting and get the dog where there is game to be had. He'll soon learn. Take him along with the bird dogs, on a check cord if necessary, but let him be there and he will soon catch on. Airedales sometimes point birds with raised forefoot just like a setter; my own dog Blaze usually raised the forefoot slightly, but his best cue was a trig eager attitude of fixed attention, standing motionless which generally meant a quail or grouse in sight.

As to size, there is a great variety of opinion. Belmore Browne, the famous hunter, explorerartist, raised a lot of Airedales in the Rockies and they always kept the smaller ones and disposed of the big stock. His reasons were that as a rule the smaller Airedale, around 45 pounds, was the brainier fighter. On the other hand some of the best lion and bear dog Airedales are picked around 60 pounds, and that by well-known handlers. Pere 


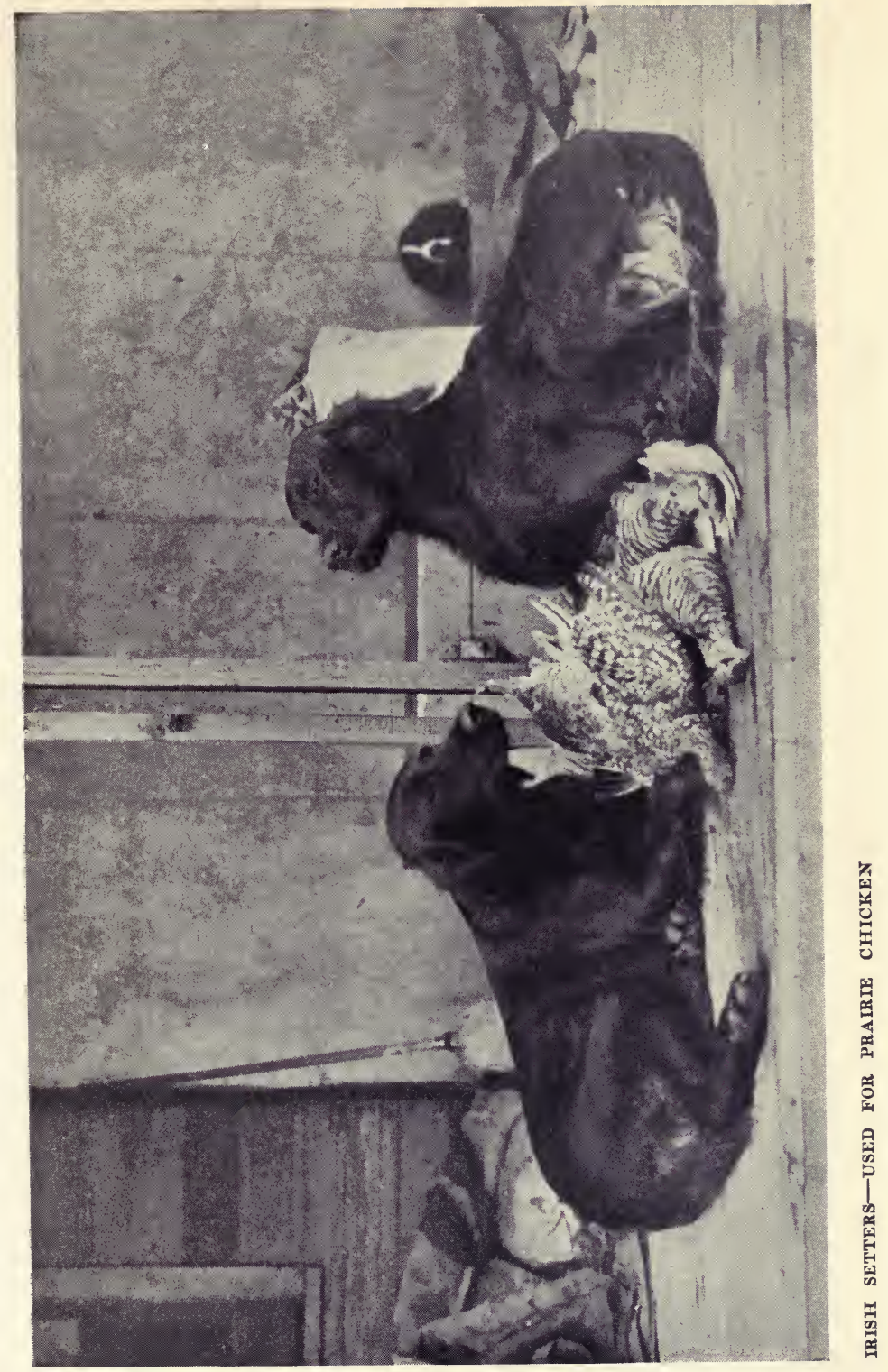




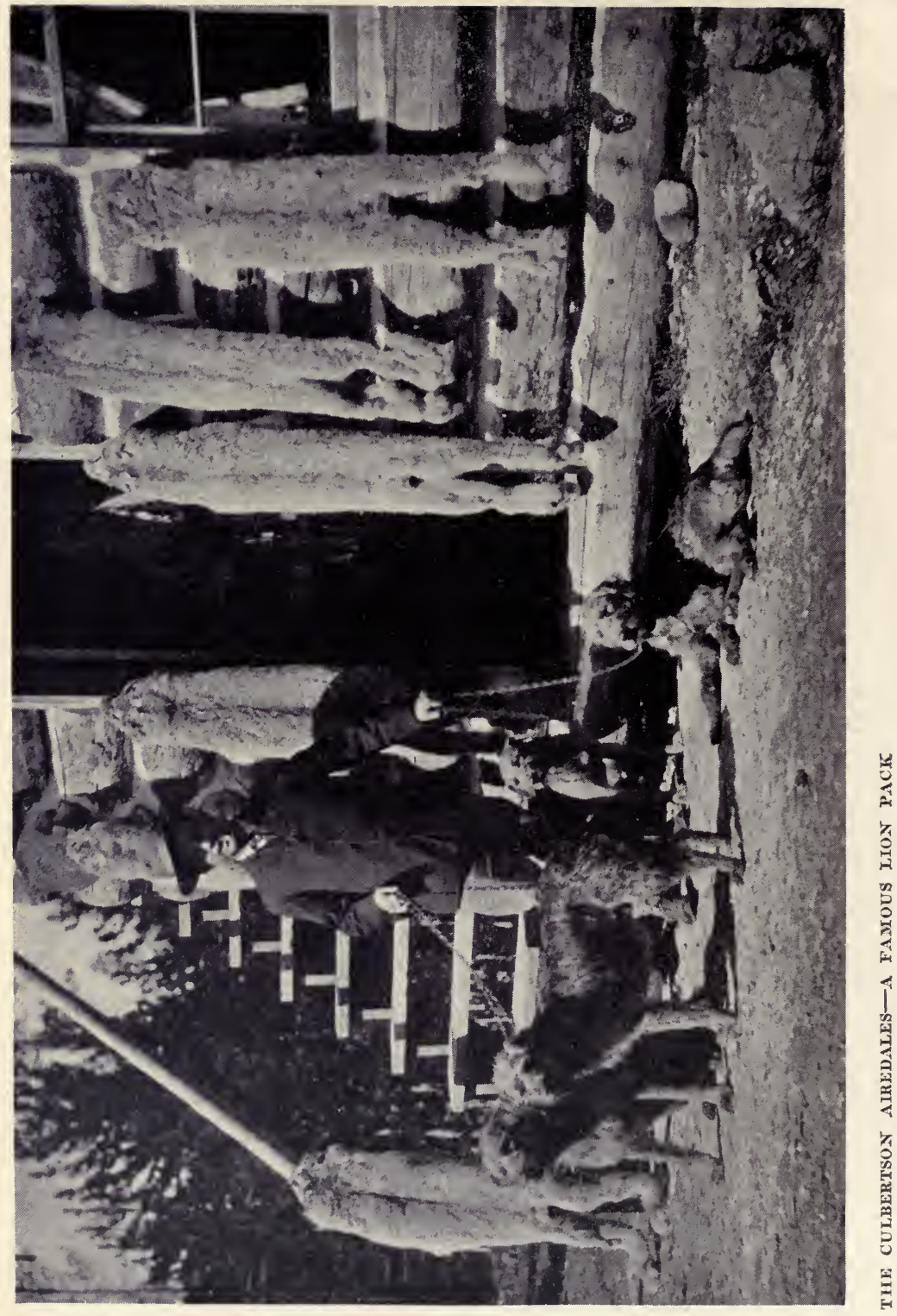




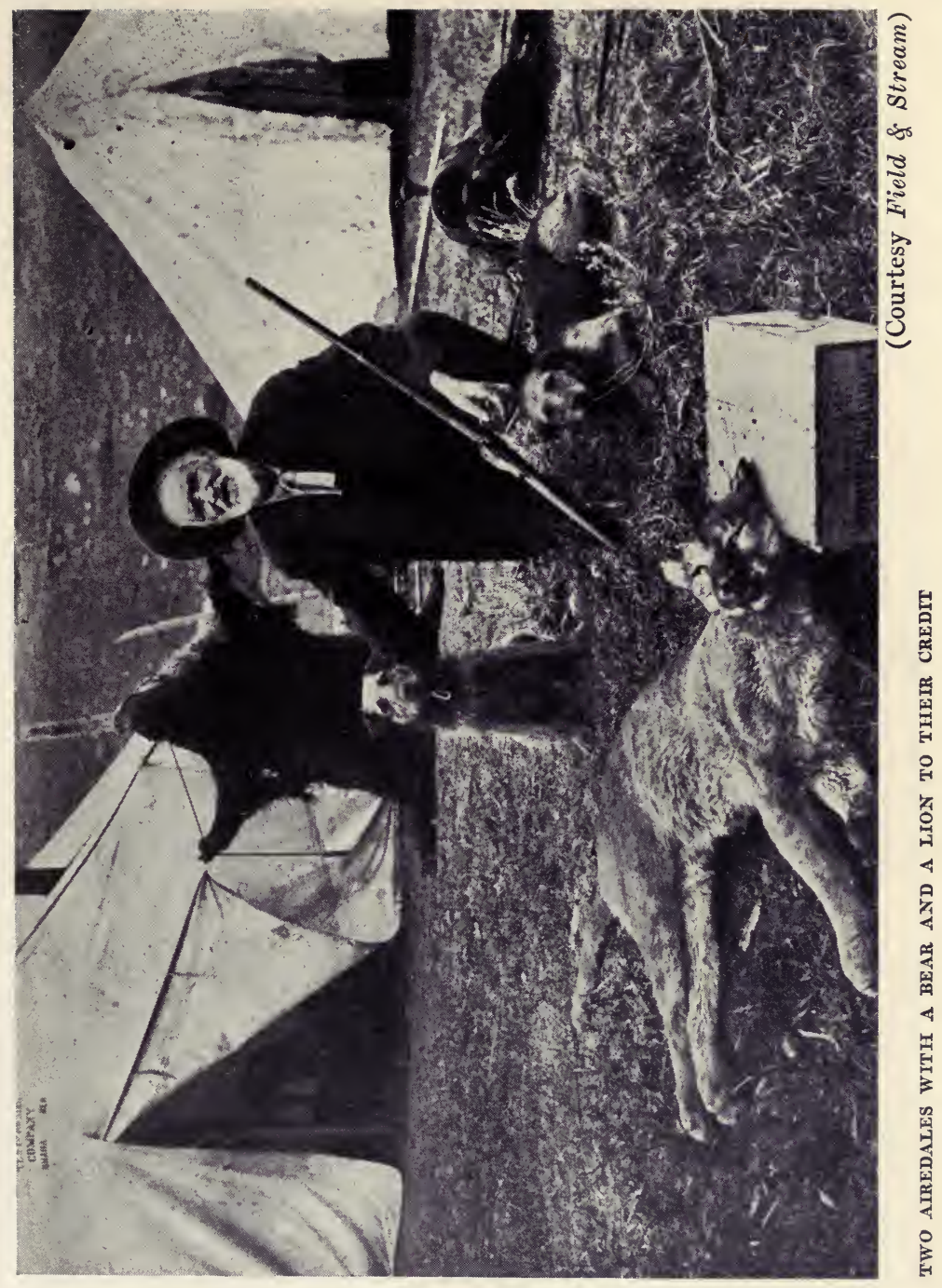




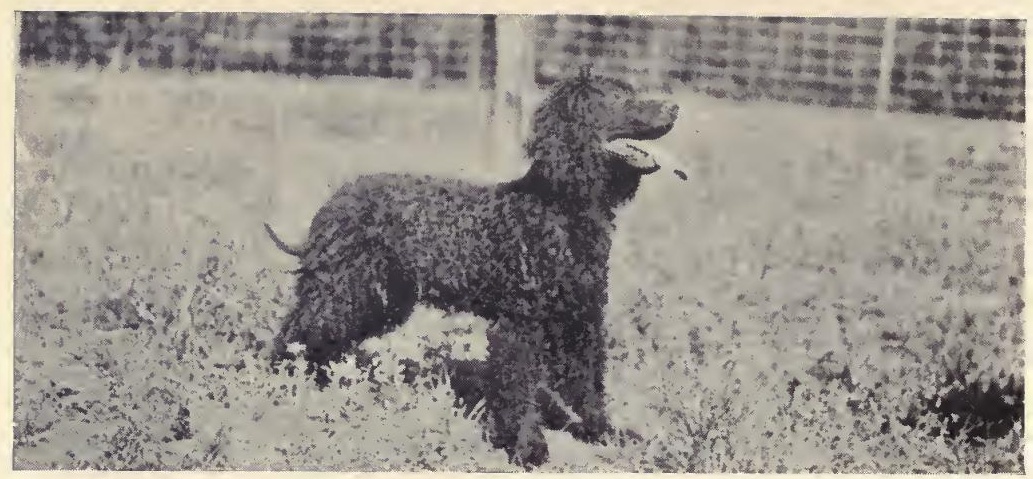

MISTER DOOLEY-ONE OF THE BEST BRED IRISH WATER SPANIELS IN THE UNITED STATES

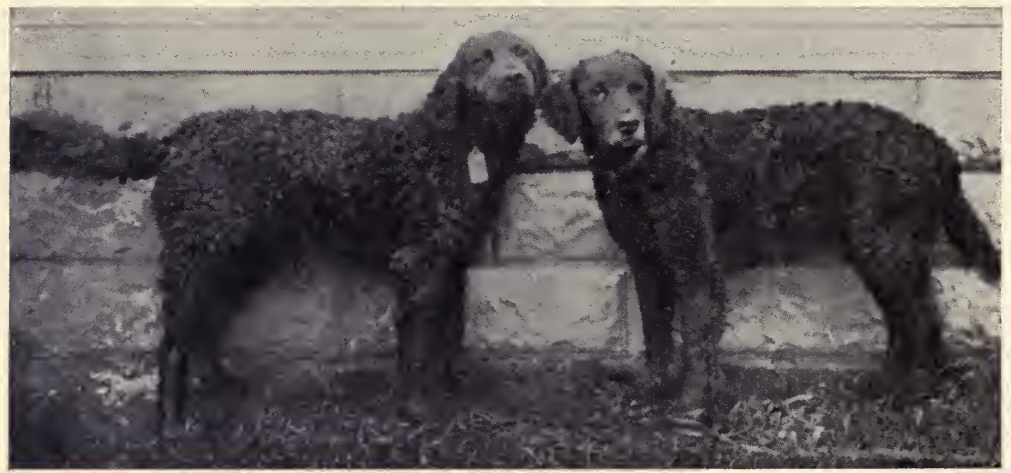

TONY T. AND BESSIE-NOTED CHESAPEAKES

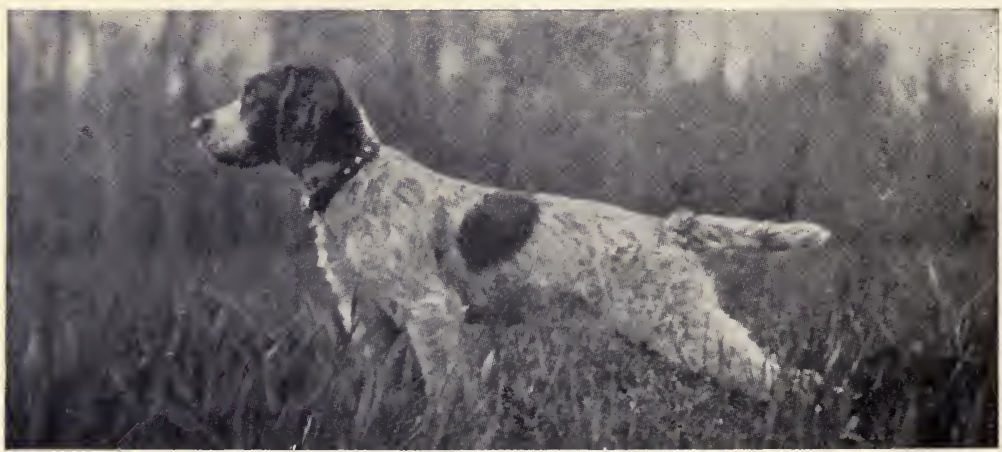




\section{SPECIAL FIELD DOGS}

sonally I would prefer the larger dog as tending more towards his hound than his terrier ancestry for we must not forget the otter hound of old England in our zeal to make a pure terrier of the Airedale.

Of famous Airedales which have made good as hunters, we might mention the Culbertson dogs, Chs. Soudan Swiveller, Kootenai Firebrand, Kootenai Chinook, Lord Knobbler, the Oorang dogs, Clonmel Cadet, Reservoir Thunderbolt and a host of unknown others owned by admirers of the breed who have written me of the performances of their dogs. Again and again I hear from this and that sportsman who has trained his Airedale exclusively on grouse in Maine, pheasants in New York, quail in Michigan, chickens in the Dakotas, woodcock in the Carolinas; and the performances of these specialists equal anything usually expected of a first-rate setter or pointer. It just shows what an Airedale can do with feathers; what he can do with fur is already well known.

Occasionally one gets a chance to import a fine dog from England or decides to do so to improve his own stock. Regarding the method of procedure I quote the following letter from my good friend Wyndham Martyn, the well-known British sportsman: "I understand the increased rates 
now obtaining in England have raised ordinary passenger fare about $50 \%$ and assume dogs would also be charged extra. Ordinarily the fare from Oxford to London (about 55 miles) is two shillings or under fifty cents. If your brother sailed from London he could take the dog in a taxi without extra charge. If from Liverpool the rate might be $\$ 1.50$ or if from Southampton 60 cents, approximately.

"On board ship, a round rate of $\$ 2.50$ was formerly charged by the steamship people.

"This may be altered. When once you have your dog on shipboard you are not allowed to keep him but must seek out the ship's butcher who will look after him. As most of these men are sportsmen in a mild way they get fond of their charges. The writer has never seen a dog of his looking any the worse for the trip except they may err on the high side by reason of little exercise and high living. For this care the butcher should get a couple of dollars.

"As to the choice of bird dog in England, that depends entirely on the type of shooting. A pointer is sometimes called a 'fortnight dog.' By this is meant that he is most useful during the first two weeks of the partridge season (Sept. 1 
to 15). The big shoots in England during the partridge season take place mainly over roots, turnips, etc., and as there are so many birds a very fast dog is necessary. And for nose and pace no bird dog equals a good pointer.

"If you are going to a mixed shoot where you walk up your birds and may have fur as well as feather (hare shooting opens on August the first) a setter is as good as any. As to what sort of setter depends mainly on the kind of farm you are shooting over. Irish setters are inclined to be wild and 'break their fences'; while the Gordons do not fall into this sin, but work slowly and surely. The English setter is perhaps the best but there is very little in it.

"If you are going on a 'rough shoot' where you must walk up your birds, rabbits and hares, a spaniel is pretty well the best utility dog. They are very easy to get in England and are in a vast majority in ordinary shooting parties.

"The spaniel is not a fast, wide-ranging dog, and for the reason that we cover bigger territories here than in England they are not much seen. Sussex, cockers or field spaniels all have their warm admirers and do good work in England owing to restricted areas. Retrievers flat-coated 


\section{THE AMERICAN HUNTING DOG}

and curly are also used. In the event of your not knowing what sort of shooting you are going to have, we recommend a setter, especially one which has undergone successfully field trials." 


\section{CHAPTER V}

\section{PUPPIES}

To have or not to have-puppies-that is the question; and it besets many an owner and still more the prospective owner. The question has its pros and cons, as most questions have. When your bitch comes in season, shall you breed her, or shall you deny her nature's supreme function? If buying a pup from a kennel, shall you get a pup just weaned, or shall you spend more and get one in adolescence and more out of the reach of distemper? If you don't breed the bitch she will have to be guarded with extreme vigilance and care; if you do breed her she will have to be guarded for several weeks after the mating to prevent further alliance with mongrel dogs. And, at the end of the period of gestation, in sixty-three days or less, you will have the manifold cares of being superintendent of a canine maternity hospital and foster-father of some six or more wee, furry packages of canine infancy. If you buy a young pup, just weaned, from the kennels, his cost 
86 THE AMERICAN HUNTING DOG

will be less than for an older dog, and you will enjoy many delicious moments in watching his infantile poses and antics, but your risk of losing him from distemper or some other ailment is much greater than with a dog a year old.

It depends principally upon individual temperament. Some men love children and pets and get hours of enjoyment out of caring for them and playing with them; others are more self-centred and are easily irritated by the doings of irresponsible pups and mischievous children. The former class, fortunately in the great majority, form the principal prop of the great institution of matrimony, by which the world do move; the latter, constituting the bulk of the readers of smart and snappy magazines, are the main pillars of the sacred institution of alimony. To which class you personally belong should decide whether you should own a pup or pups, or should invest in a young grown dog. Puppies are a joy forever; they are also an intolerable nuisance. Like children, there is something infinitely tender and appealing about them that tugs at the very heart strings of mankind; and, like children, they want the earth with a stone wall around it, they strew a path of ruin and disorder behind them, and they inevitably contract a variety of infantile diseases. 
To me a two-months' pup is a source of pure joy. His little, fat, waddly hind legs; his foreverwagging, busy deevilduyvil of a tail; his bright, inquisitive little face, with pricked-up ears and head cocked to one side; his hopeless innocence in this naughty and cruel world; his slashing bravery with which he tackles things that discretion would counsel him had better be left alone; his utter, appalling ignorance of the proper times and places to do whatever his fancy for the moment listeth-all these are a constant pleasure to me to watch. They do not irritate me; I laugh at his misdemeanours, condone his faults, revel in his virtues, and adore him from the end of his small black muzzle to the tip of his tiny tail!

You miss a lot when you begin with a year-old pup; yet you avoid a lot, too. During those early months he will do at least a million things to aggravate you and make you lose your temper, and many a time you will shake your head and call him a hopeless lemon. And then, being a thoroughbred, he will be far less hardy than a mongrel pup and will take all his ailments badly, giving you many an anxious hour. But, if you bring him through, he will be your dog, ten times more so than if you started with him later in life. And, 


\section{THE AMERICAN HUNTING DOG}

if you lose him, it will go ten times as hard with you!

Whether to keep bitch or dog also comes under the same heading of individual temperament. A bitch is more docile and affectionate; as smart as or smarter than the dog; is infinitely more trouble to keep because of her seasons, recurring every six months and lasting for about three weeks; and she is more hardy than the dog, following $\mathrm{Na}$ ture's universal law of making the more important sex of the species constitutionally sounder. The dog, on the other hand, is much easier to keep, is harder to teach, more quarrelsome with other dogs, more liable to disease, and, unless a prizewinner, is a source of no income to you as a producer.

In general, I should not advise keeping a bitch for a man who has a family of growing children, already a great deal of care to their mother; she will be only one more thing to look after. But, for a city sportsman who can afford to have his bitch kept at the country club, and looked after or bred properly when she comes in season, a bitch would be a very good and profitable choice. She will mind her strange master better afield, will stand railway journeys and exposure better, and will yield him a nice penny from the sale of her 
puppies. For a man living in the country, with a big place and grown-up children, or at most but one or two youngsters, the bitch would be a very good choice. Such a man would have the leisure and inclination to breed her and raise high-class pups on the side, and an advertisement of any such litter in any one of the sporting magazines will easily clean out the whole lot, if good ones. Keeping the best pups for a future sire, and one or two of the bitch puppies for future matrons, he has the basis of a nice kennel-good, strong, line-bred stock. One more sire, bought later from outside stock, would save him from the evils of too much line breeding, and, by putting the puppies out to walk with farmers in the neighbourhood, after they get over eight months of age, he has his stock where it can flourish healthily and will be more immune from ravages of disease. Most farmers will board your pup very inexpensively; some will take him for the protection to the farm that a dog of any kind always gives.

Your first pup will naturally be bought from some kennel whose stock you fancy. Most kennelmen are reliable, and they have had the advantage of having seen and noted the puppies when they were just born, which is the only time that any idea can be formed of their probable 
future behaviour, for after the first few days they all become so many little fluffy balls of fat and cannot be judged as to bonal structure. However, when just born, a very fair idea of the future conformation of head and body can be formed. Later, at about two months, you can judge of the most important anatomical feature of the pup, his couplings or backbone vertebræ joining the last ribs to the pelvis bones which support the hind legs. These vertebræ, if you will study the skeleton of a perfect dog, have long, strong side-lugs, or "processes," as the professors call them, to which the strong muscles of the loin are secured. If this back structure is not broad and strong the pup will never amount to much. Thin and weak there, he is like a ship with a weak keel, hopelessly unseaworthy. Leave the selection of these points to the kennelman if at a great distance; if anywhere within even five dollars' carfare, better go and pick out your pup with his help. For Airedales, spaniels, beagles and some hounds, the Eastern man will find suitable kennels within carfare range. For pointers and setters, the Middle West seems to be headquarters, and the pup must be bought on pedigree and your kennelman's selection. Most of them are entirely willing to ship you a pup on approval, so your whole 


\section{THE AMERICAN HUNTING DOG 91}

risk is the express fare, which amounts to about $\$ 3$. A good setter or pointer pup will stand you $\$ 25$ at two months' age, maybe $\$ 40$ when a year old, and $\$ 30$ at six months. Hounds run from $\$ 5$ to $\$ 15$ for pups of about six months' age. The business of shipping them is well organised; even a baby doglet of two months, five days on the road in the dead of winter, will arrive at your home in good shape. They send with him a milk bottle, a box of crackers and a tin tray tacked inside the crate, and it is the express company's business to see that he is fed en route, and, if they are so slow that all the food gives out, it is up to them to feed him themselves. Older pups require nothing but a box of dog biscuits and a water-pan, and are chained inside the crate, a cruel and usually unnecessary custom, brought about by the fact that so many people ship dogs in weak, worthless crates and then hold the express company responsible for the canine wonder that went adrift.

Assuming that you have ordered a two-months' pup, presently there will arrive in your midst a fat, fluffy ball of dog flesh with rubber legs and jelly backbone, a little waddling pup that will keep the whole family in a turmoil from the moment he arrives. Every one wants to hug a baby, no matter whether human or canine, and your puppy will 
come in for his full share. He will be lively and aggressive himself, lick every one's face, explore the entire premises, get himself into trouble in the first five minutes in your house, and turn your whole schedule of existence upside down-for the first few days! Then you get used to it, and do not take him and his wants so seriously.

About the first problem that arrives, and that with the going down of the sun, is whether to make a house dog of him or a kennel dog. Both ways have their advantages; the kennel-raised dog is hardier and more independent and better as a watchdog if the premises are large; the houseraised dog is more intimately your chum and the pet of the family, he will be less hardy, because half his life-the hours of night-are spent indoors out of the fresh air, and, if the premises are small or limited, he will do better as a watchdog if kept indoors, for with him on guard the house cannot be entered nor the dog poisoned, as will likely happen if kept in a kennel outside. Housebreaking him is a small matter if rightly managed. Tie him to his mat or sleeping corner with a short chain, and take him out the last thing at night and the first thing in the morning, as regularly as the sun rises and sets, punish him for transgressions at the scene of his crime, and you will have him 
well broken in three weeks. A very young pup of two to two and a half months cannot go over-night without relief and had better have a newspaper placed handy. To whip him or punish him hard for transgressions is pure cruelty; you would not do so to a ten-months-old baby, nor is the pup any more responsible. But no dog likes to soil his quarters, and will restrain himself as long as possible if the chain is so short that he cannot get away from his sleeping mat.

Whether he has a kennel in the yard or a mat in the house, let it be a fixed place that he can call his. When doggie has no particular place to sleep, it does not take him long to find out which chairs are the most comfortable, and he will inevitably fill them full of hairs and make them look worn if allowed to sleep in them. The time to check this tendency to climb up into chairs is when extremely young. At the first attempt he is to be lightly punished, scolded and warned. Pepper was the only one of my pups who could not be broken of the chair habit. No amount of licking . would cure him, and at the first sound of the wife's footfall descending the staircase Pepper would do a grand sneak out of the morris-chair in the library and look up at her as innocent as a lamb when she came into the room. But a warm chair-seat, 


\section{THE AMERICAN HUNTING DOG}

plentifully sprinkled with white hound hairs, would give him away, for all his angelic expression! Blaze and Scout both attempted to use the chairs, but both were headed off in early infancy. The thing to do is to provide a thick mat of, say, three inches of cotton batting loosely quilted, the facing being gray flannel. Such a mat should be at least two feet by three feet in area (22 by 30 inches will do for a pup or a small dog like a spaniel or beagle), and can be dusted, aired and sunned, or sprayed with flea disinfectant, and is put away in some closet during the daytime. During the evening your dogs will lie on the rugs before the big log fire, but the floor is never a really comfortable sleeping place, besides being draughty and conducive to rheumatism. It will answer until you go to bed, but, if you have provided no mats, just see how long it will take those dogs to appropriate the chairs, once you are well asleep!

For a kennel, a packing-box 20 by 24 by 32 inches will stand you 50 cents at the shoe store, and you are to erect a pair of roof rafters at each end and nail to them on each side a roof made of two boards of rough 1 by 12-inch hemlock four feet long, four boards in all. The gable ends are filled with the erstwhile top boards of your packing-box, the rear gable being hinged so as to make 
a triangular door for getting at the interior of the kennel to clean it. Then, with a circular saw, cut a dog door in one side of the end, 10 by 16 inches, and the kennel is ready to line inside with ordinary tarpaper, which the builders use for sheathing, and outside with one of the many brands of ready roofing paper. It then receives a coat of paint outside and is ready to set up, at a cost, complete, of about $\$ 1.50$. To set up properly, remember that the dog likes a high place to roost, and that too near the ground means liability to rheumatism, pneumonia and distemper, so drive in four stout posts and saw off their tops about 8 inches above the ground and set the box on them, nailing fast with wire nails driven down through the bottom of the box into the posts. For summer, your mat will be the best bed to put in the kennel, for then is the height of the flea season and the kennel will need to be sprayed every week and the mat taken out and aired and sunned. The inside tarpaper also helps in discouraging the flea population, but not very much. A good kresol dip, consisting of a tub of water with two tablespoonfuls of kresol in it, makes a real flea-killer, annihilating every one; but even this they will live through if not freshly mixed.

For a bitch the kennel had best be two-storied, 


\section{THE AMERICAN HUNTING DOG}

with a sort of veranda up under the roof. Your packing-box simply needs its top left on, and above it the roof is erected with a running board a foot high all around, and the roof a lean-to with the upper side open. Here the bitch can retire for a rest when she wants to get away from the puppies for a little while-a vacation much appreciated by any mother, human or canine!

For winter bedding good clean straw is better than the mat, for it permits the dog to make himself a nest and is warmer and less draughty than the plain mat. Excelsior, shavings, hay, and leaves are all objectionable, because of splinters, fine dust, hay seeds, dirt, etc., which the dog breathes in through his nostrils when lying in such a bed.

The housing problem for your pup is by no means through when you have provided mat or kennel, for some breeds, notably setter and spaniel puppies, so crave human companionship that they will howl and bawl if tied to a kennel, also if tied in the cellar, and ditto if tied downstairs. In point of fact they want to share your bedroom with you-which you will have force of character enough to forbid! Install him in a place free from draughts and commanding the whole of downstairs, and you have him at his best as a watch- 


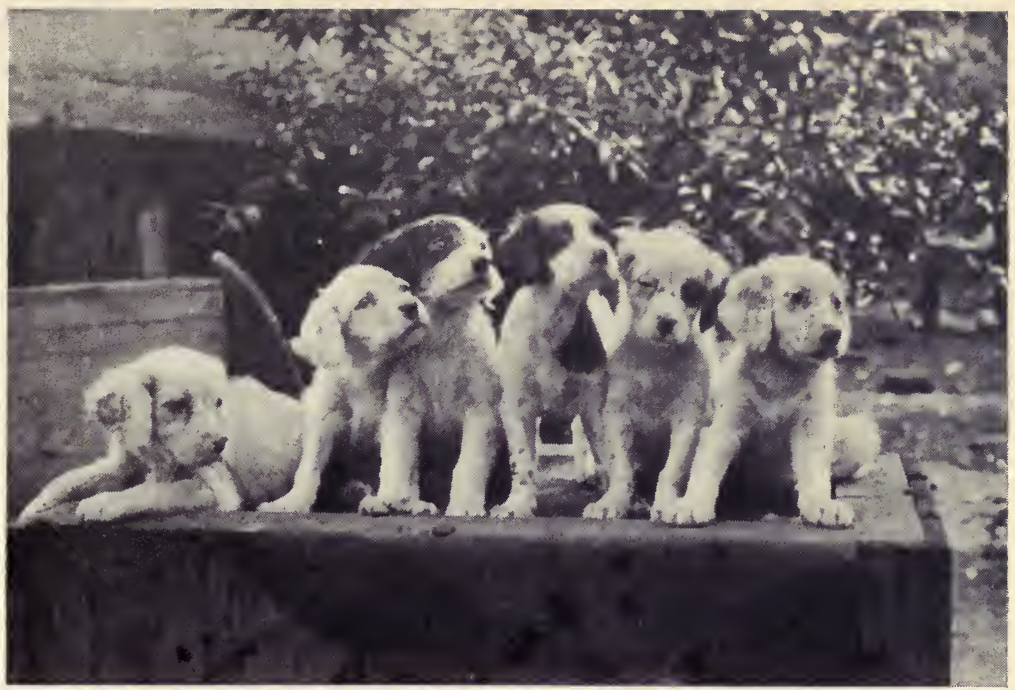

A NICE LITTER OF SFTtFR PUPPIFS, TWO MONTHS OLD

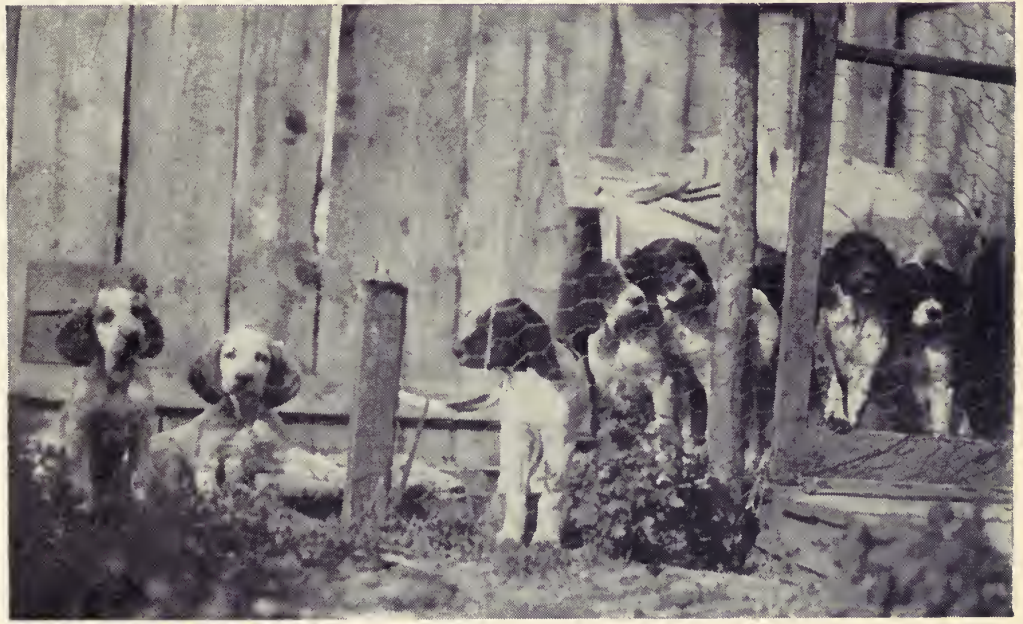




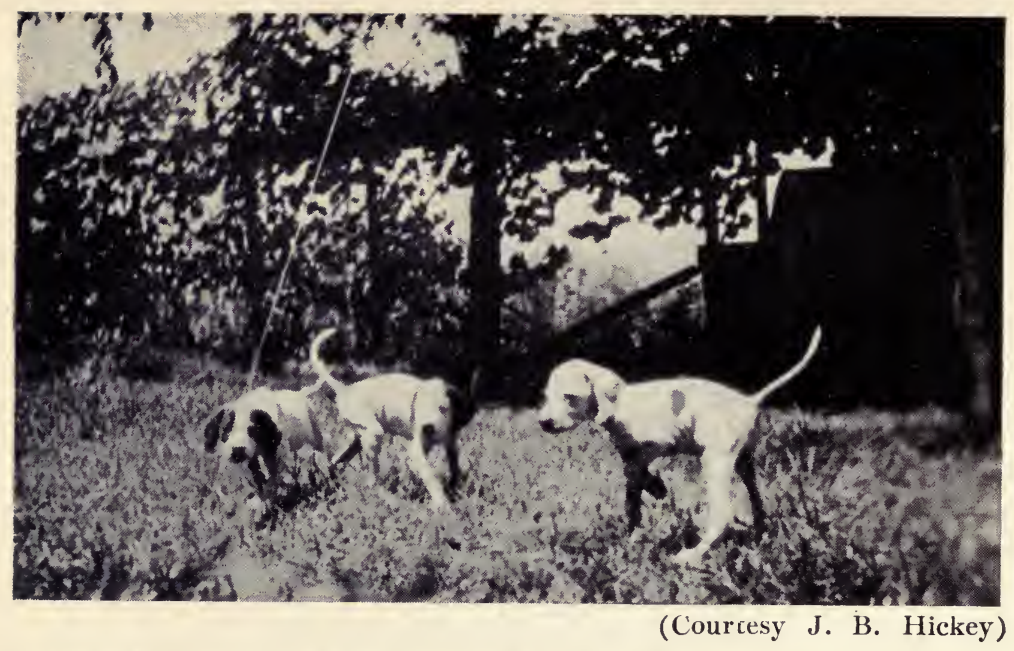

THREE POINTER PUPS ON POINT AT TWo MONTHS AGE

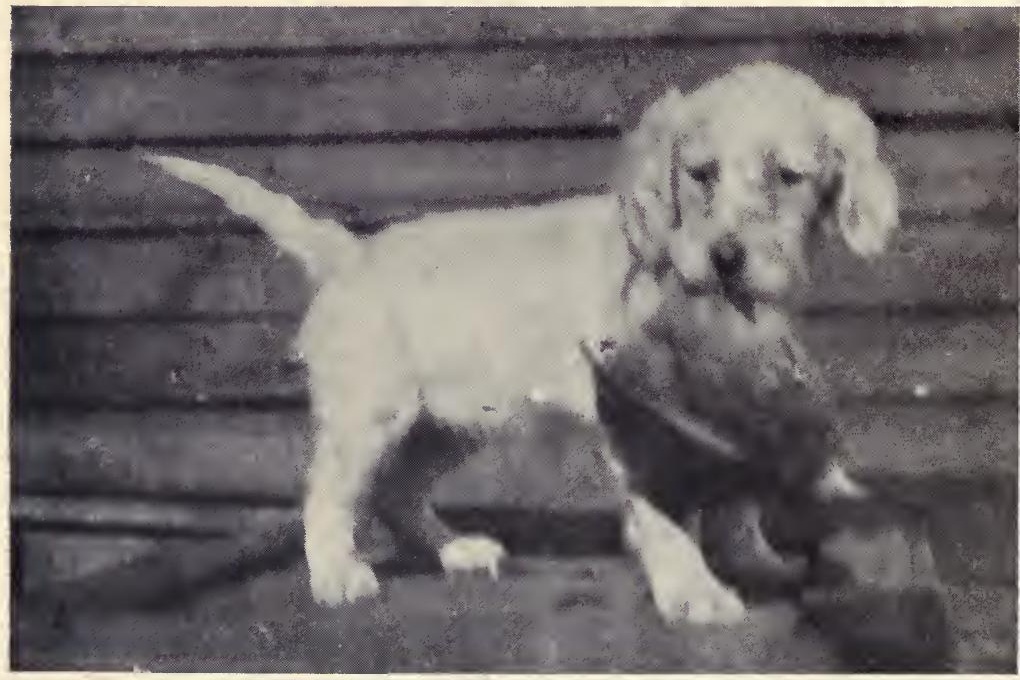

RETRIEVING AT SIX WEEKS AGE-PUP BY SIR ROGER DE COVERLY II AND BLUE GIRL JANE 
dog, which is one of his principal functions in life. Airedales and hounds are more phlegmatic and will consent to be tied to the kennel in tender puppyhood without much fuss. Even the setter gets used to it after the first few nights, but you are in for a siege with him for the first night, anyway!

Next comes the problem of feeding the puppy. Nothing sets him back so much as improper feeding, eczema for Airedales, worms for all pups, and proneness to disease being the sure consequences of improper feeding. A two-months' pup requires a good many light meals a day; five is none too much; at three months, four; at six months, three, which is kept up until eighteen months, when he begins to hoist his leg and is mature. Then two meals, a light snack for breakfast and a heavy meal at night, is more than plenty, lest he grow fat and piggy. The two-months' pup will require milk and cracker the first thing in the morning; oatmeal and dog biscuit well broken up and milk and meat broth poured over it for breakfast; a lunch at 12 of broken-up, stale bread which has been baked to a golden brown in the oven, over which is poured a good gumbo of meat broth and table scraps; a bone to gnaw and a dog biscuit at 4 P. M., and a good meal at night, consist- 


\section{THE AMERICAN HUNTING DOG}

ing of table scraps, dog bread, and meat broth. Once a week a tablespoonful of raw meat chopped fine; bones a-plenty, unless they happen to be hard, sharp, splintery leg-bones of a chicken, when they might puncture the dog's intestines. A dog's stomach has so much hydrochloric acid in it that he can swallow whole a bone as big as a silver dollar and digest it as easily as a human will cake. The thing simply turns to jelly in his stomach and goes into his own bonal structure forthwith, whereas if we tried to eat the same bone we would need an emetic and a surgeon! Bones that form hard splinters, however, are to be guarded against.

In cereals, corn bread and oatmeal are both good, but must be stopped with the coming of hot weather and also on noting any symptoms of eczema. The latter comes from over-heating foods, or too rich a diet, too much meat and not enough stale bread baked brown; or it may come from garbage-pail food and too little nourishment, but generally, in the case of the over-zealous sportsman, with too rich a diet. It shows up in continuous scratching behind the ears and under the armpits. Remedy: reduce the meat element of the diet and wash coat with flowers of sulphur in crude oil or some such patent preparation as 
Glover's or Boving's Mange Cure or the Kenwyn Koat Kure, all of which are essentially sulphur and crude oil. A light case may be cured by washing with ordinary Epsom salts and putting a tablet of flowers of sulphur each day in his food.

I am a firm believer, also, in that little piece of sulphur in his water bowl. It has often been scoffed at in print, but my training in chemistry as an engineer tells me that that sulphur will be continuously forming a slight reaction with the water to produce weak sulphuric acid, which is just what the dog needs to make hydrochloric acid in combination with the salt in his food, and these two acids are among the principal reagents in the processes of digestion.

The above diet can be kept up, with variations, throughout the dog's life, only the amount being reduced as he grows older. Two pounds of dog meat at 12 cents a pound will keep the broth-pot stocked with the basis of a dog mulligan, and all table scraps are to go into this. One box of dog biscuit at 20 cents will last a week, and this gives you a bill of about 50 cents a week for your dog's keep. Never feed him ancient or smelly meat; he is just as liable to ptomaine poisoning as you are. Throw it away and let him fast, if the meat gets away from you in midsummer. 
I would put exercise as the next important thing in the puppy's care. At first he is just a waddling billiken, hardly able to hold up on his pins, and will achieve a walk with you of about a block from the house and back, which is plenty. Watch his tail; when it drops and is inclined not to wag, he is tired and you had best pick him up or stop a little while for a rest. In snowy weather he will get wet and cold, so wrap him up or build a fire and let him lie down on your coat before it for a spell before pushing on. When Scout was three months old we had an example of that very situation. Our walk to the woods proved to be in rather deep snow for the pup, and he tired and began to shiver before we had gotten into them very far, maybe half a mile. I noted the hanging tail and listless expression, and so made a little camp at once, building a fire and spreading out my coat before it for the children and pups to sit on. Blaze was afraid of the fire and had to be held near it before he would get used to the sensation; otherwise he preferred to sit and shiver out in the snow, which was just what I would not let him do. Scout, however, lay right down with his wet belly to the fire and let the heat warm and dry him. After half an hour we pushed on back home and both pups arrived in good shape; without this stop 
and campfire it might have been a case of cold or pneumonia for both of them. Again, setter pups will jump into the water at any time of the year and get thoroughly chilled. Fearlessness of water is in their blood from their spaniel ancestry, and you must watch out for cases of cold or pneumonia from that cause. An old coat thrown over a shivering pup and his little body set near a fire will save much trouble. Never let him shiver himself dry, as is sometimes done with a grown dog.

At four to eight months your pups will need two walks a day. Even a turn around the block will give them several miles of run, and a walk to the fields out of town and back before breakfast will mean ten miles of exercise to them. Then, as pups, they must be kept locked up or tied up all day, for even a ten-months' pup will run away-all the world is his friend! It is better to keep them close until they get their growth and know who are their own people. A yard, even six by ten feet, with a six-foot chicken-wire top, will give them lots of room to run about. Two pups will then keep themselves in fine trim by playing and quarrelling all day when not asleep in the sun. Tied up by a rope, they will wind themselves up in no time; the only substitute for a yard is a tight rope stretched between two posts about fifty feet 
apart and four feet above the ground. On this is a large iron ring to which the dog's short leader is attached. With this scheme he gets a certain amount of exercise, but even then will spend most of his time at the house end of the leader, waiting for some one to come out and play with him or show him some attention. One lone dog has a sorry time of his puppyhood, for his sole romps are when master is at home. Two pups in a yard will do much better, and when they get their growth-say, 18 months-they will be allowed at large about the grounds and will play with each other all day long, racing and tearing about, wrestling on the lawn and keeping each other in ironhard condition.

From the ages of six to eighteen months the pup is going through his cubhood and. will try your patience to the limit. Over the back of one you will ruin a perfectly good umbrella, which you vow is worth many times over the present value of the pup! To another you will charge the dismemberment of milady's hat and the frayed condition of your rugs; to them both, lost articles innumerable; holes in the lawn; a ravaged garden; many hours spent in tracing them all over town; in washing them after rolling in carrion and filth, which many of the wilder breeds, such as Airedales 
and hounds, delight in, the same as bears and wolves; and in teaching them simple dog manners. The time for this is between the ages of three and eight months. Then is the time to teach the pup not to run after strangers, not to jump and fawn all over you, not to fear the water, not to make amorous advances towards other dogs; to learn and obey your various whistles, to follow at heel, and to associate shotguns and rifles with good times afield, so that he neither fears the sound of the shot nor dislikes the gun as an implement of sport. From eight to twelve months is the best time to start yard breaking the bird-dog pup, and at twelve months he should undergo a regular course of training with the force collar.

For hound and Airedale the same period is to be spent in practical hunting afield, at first with older dogs who know the game, later by himself after hunting has become a passion with him. It may be said here, in passing, that coonhounds, beagles and bassels are less apt to be gun-shy than foxhounds, which latter, having, as a rule, ancestors who have hunted foxes in the South, have no gun in their blood and fear it from the first. Pepper was almost incurably gun-shy, being finally cured, yet, at that, not caring to hunt when there was a gun in the game; yet as a bench dog he has already 


\section{THE AMERICAN HUNTING DOG}

won a number of blue ribbons, defeating several champions, and as a field dog, hunting foxes with horse and hound, he has more than made good and entered the great Brunswick field trials this season. Good Redbone, Pennsylvania or Portsmouth hound stock is what we want up North, where the fox is run by the hound and shot ahead of him by the hunter. For such a pup, field training, which is simply condensed experience under the leadership of an experienced dog, is what he needs and lots of it. For an Airedale pup I would advise his going along with both bird-dog and hound and learning both games within the limits of his ability. I have heard from many owners of Airedales who use their dogs on quail, ruffed grouse and woodcock, and they make good quite as well as spaniel or retriever or any other breed not so highly endowed with the sense of scent as the setters, pointers and hounds. 


\section{CHAPTER VI}

\section{DOG BREEDING}

IF your puppy is a bitch, she will come into her first season along about the ninth, or even eighth, month. It is well to pass this season and the next one, six months later, without breeding her, for her body is nowhere near fully developed and good stock is not produced from immature cells. But at a year and a half you can make up your mind not to deny her, and the problem of what dog to breed to at once comes up. Plain arithmetic would say that half of each parent will be represented in the pups, one-quarter of each of the grandparents, and so on. But, precisely as in human kind, the resulting pups of the union follow no such law, but are quite as likely to throw back to grandparents or even great-grandparents in individual traits and markings as to take after father or mother. One thing is certain, however: the family traits on both sides will be reproduced in all the puppies, so that if your bitch errs in having too short a muzzle or too long a back, mate 


\section{THE AMERICAN HUNTING DOG}

her to a dog from a family noted for cobby backs or long muzzles, and the pups will be corrected of both faults. To be sure of pups that will be good natural hunters, breed the bitch to a dog from a family noted for its wins in field trials rather than bench shows, for the latter type, particularly in the East, has seen so little real hunting of late that not often does one of them make good afield. There are lots of exceptions, it is true, but one experience of training a pup with no natural hunting instincts will cure you of any penchant for selecting bench points rather than field ability in your sire. The Middle West and the South are full of dogs who can almost guarantee your bitch a litter of natural hunters. Such a selection smooths the way for many details later, such as avoiding gunshyness and having natural pointing instincts, for, in a really satisfactory dog for the average sportsman, fearlessness of the gun and natural desire to hunt and point should be inbred in the very bones of the pup. Scout I was such a dog; Doris and Scout II were just the opposite, and both of the latter were troublesome to train.

Two services to your bitch will be plenty; guard her against any further alliances, for it will cause trouble. At the same time a mesalliance, which frequently befalls the amateur breeder, can be 
aborted by a douche of bichloride of mercury, and at no future mating will such mesalliance have any effect on the subsequent puppies, the former belief to the contrary having been fully exploded by scientific inquiry. In general, do not pick out an old sire for a young matron nor mate an old bitch to a young dog; both matings will result in small pups. A healthy young bitch to a young dog in his second year will result in a fine litter of husky puppies. Better be on hand yourself at the service, for thoroughbreds are notional and if there is any trouble the kennelman, if left to his own devices, may substitute some other dog. As a rule there is no difficulty, for your erstwhile demure bitch has now become a brazen hussy, requiring the closest of watching both before and after service.

Your bitch must be guarded for about two weeks more after service, which should occur in the third week of her heat, and she will then return to normal and will show signs of the coming family about the fifth week. About two months after service you may look for the litter, and a quiet place with plenty of clean straw should be selected for her, and the bitch kept there. A whelping box, with a four-inch board rail, on edge, screwed all around the inside about four inches above the 


\section{THE AMERICAN HUN'TING DOG}

floor of the box, is a good thing to make, to avoid having any valuable puppies rolled on or smothered by the dam. The shelter under this shelf is protection enough until the puppy is found and restored to the family. The bitch will make her own nest in the straw of this box and you had best not interfere with her nor attempt to handle the new-born pups. She will attend to this matter herself; all you are to do is to see that each one has a warm spot next her body and that it is nursing right manfully. Right after birth also is the time to make a record of the markings of each pup and note his structural characteristics, for later the fat on his little body will hide every vestige of his future appearance. Your principal care for the first week will be to keep the mother well fed; meat, broth, bread and table scraps being given her three times a day. Milk is good, but apt to run to fat, which the bitch will put on her own body instead of passing it on to the pups. If everything is well you can see the pups grow, and they will be quiet most of the time, either nursing or sleeping. In two weeks' time they should all be fat as butter, with eyes open and every sign of getting on in the world. They are blind until the ninth day, and after the eyes open the kennel should be darkened lest their future 


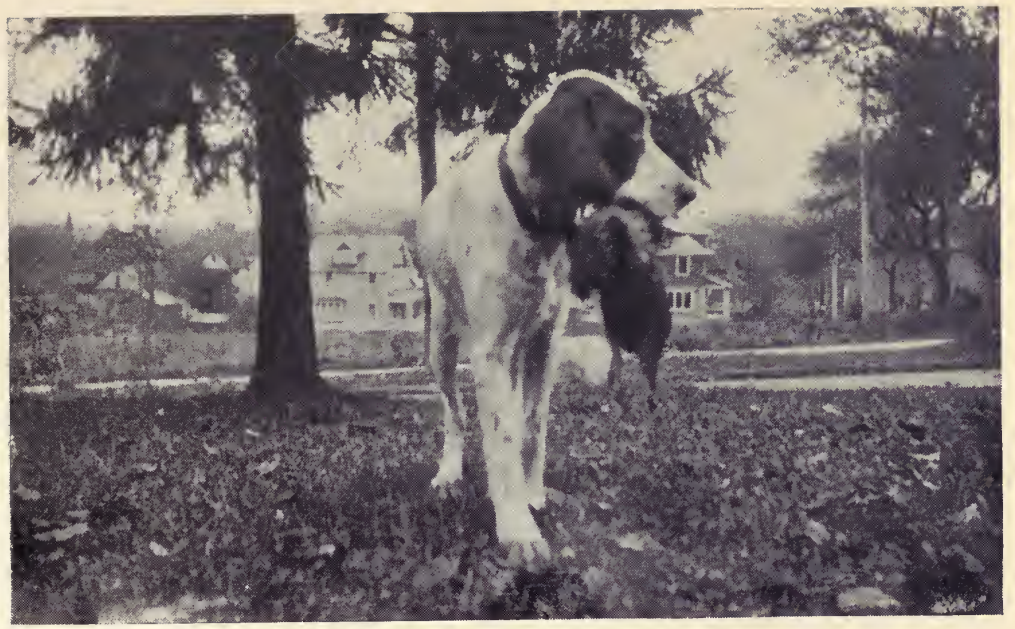

A GRAdUATE IN RETRIEVING-13-MONTHS SETTER PUP

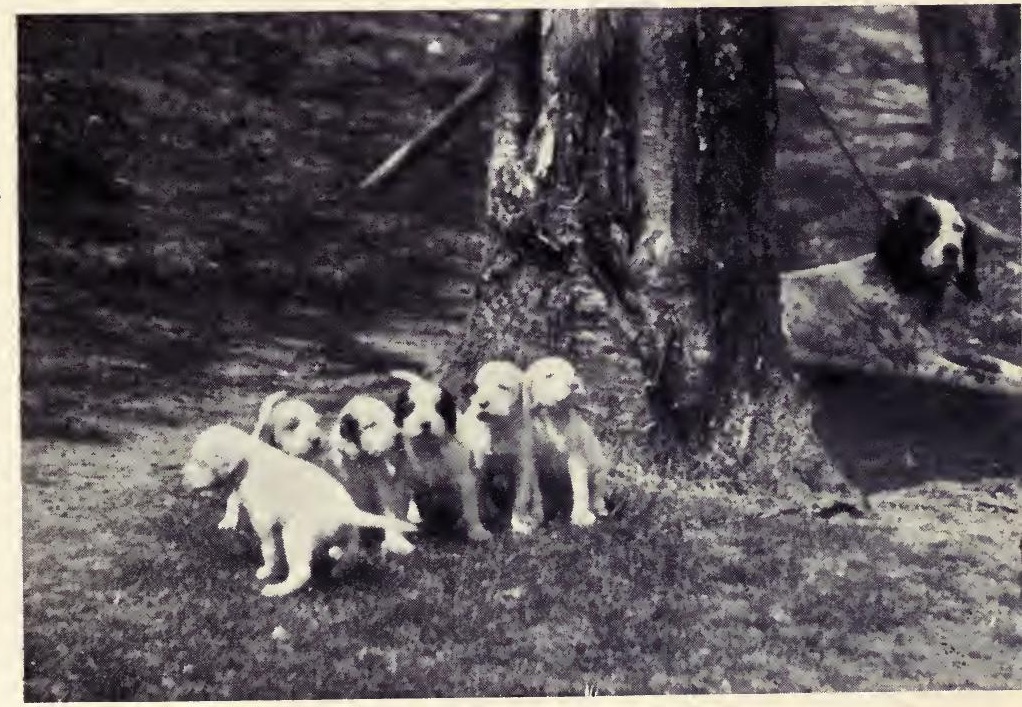




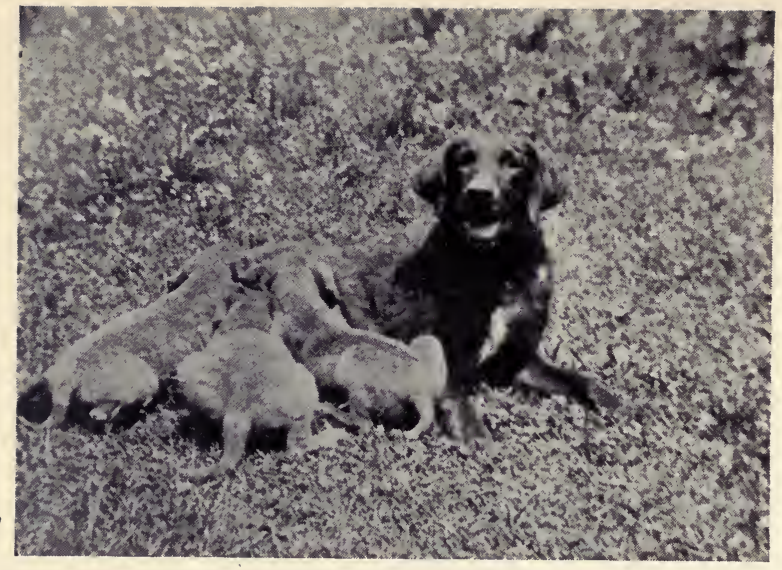

A SMALL FAMILY OF CHESAPEAKRS

BUT HUSKY AND WELL NOURISHED

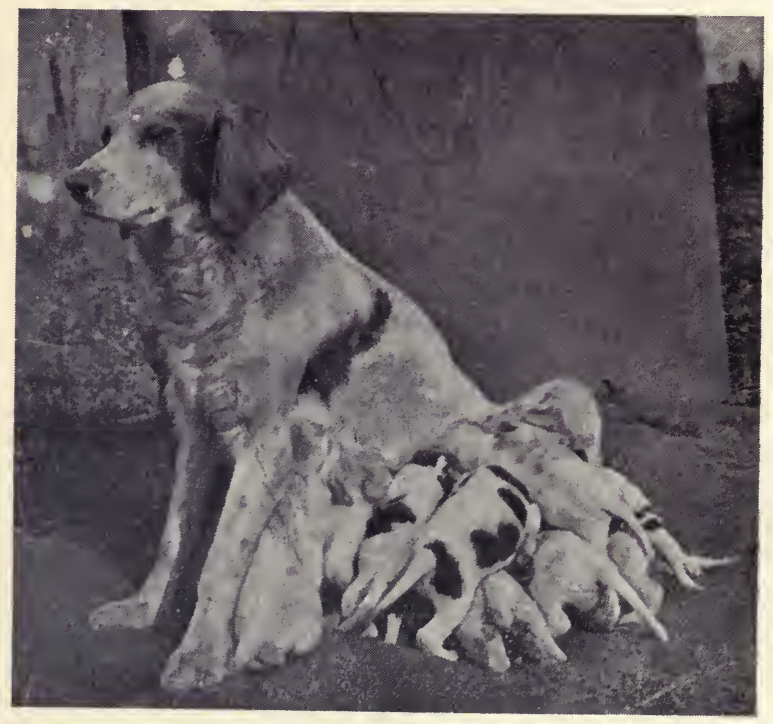


eyesight be impaired. If the pups cry and do not seem to be gaining, call in a vet. at once, for there is something radically wrong. These few weeks are the most important in a dog's life; like children, if not started right in extreme infancy, they will be handicapped for life by bodily infirmity and weakness. The ailments that afflict very young pups may range all the way from poisonous milk in the dam to worms or navel ill in the pups, all of which matters are treated in a later chapter of this book. In general, the surest way to avoid infection in very young pups is to have the whelping-room and everything connected with it thoroughly sprayed with some mild disinfectant like diluted listerine.

A bitter question here arises: If the bitch has a large family, what shall we do with the less desirables? More than five or six is all she can successfully raise, or else all of them will be underfed and liable to be carried off by the first kennel disease that comes along. Have you the heart to kill any of those soft, fat, fluffy darlings, each one of which if a thoroughbred is worth at least $\$ 25$ ? Yet it must be done, if the family is large and no foster mother available. Better arrange beforehand for a foster mother if the pups are valuable. 


\section{THE AMERICAN HUNTING DOG}

In almost every large kennel there will be some bitch available for this purpose.

When the pups are a week old, if they are to be docked or any dew claws removed now is the time to do it. A sharp scissors, dipped in carbolated vaseline, is a far better implement than biting off the tails or in any other way exposing the wound to infection. Leave the future care of the wound to the mother, whose tongue appears to be a better disinfectant than any surgical compound yet discovered. At three weeks' age, start weaning. This is a long process if properly done; as in children, any sudden change is almost fatal. The pups should be first encouraged to eat a little meat broth and milk in addition to their dam's milk. Two small meals a day is ample; more would effect too serious a change in the perfect mother food that they are getting. At four weeks the meals may be increased to three a day, and well cooked cereals, finely chopped cooked meat, fine cut liver, etc., may be introduced. At five weeks, increase the meals to four a day with the other two to be given by the dam, and at six weeks they can get six meals a day, a little each time. See that each pup gets his share, and use two pans, one for the husky ones and the other for the backward pups. Here is a well-tried menu: 1st 
meal, toasted stale bread and milk; 2nd, oatmeal and meat broth with a little finely chopped meat; $3 \mathrm{~d}$, puppy biscuits such as the maltoid puppy "bones"; 4th, bread and milk; 5th, oatmeal and meat broth, liver; 6th, a little raw meat scraped fine and some puppy biscuit "bones" to play with. The dam should have a shelf or other high place to lie down on, in sight of the pups, for they will try to follow her around and get chilled or lost if she goes away and yet she must get more and more rest at this time while her milk is slowly drying up.

At two months the pups are completely weaned and ready to sell, which brings us back to the beginning of this dissertation. Earlier than this it is not safe to take them away from the dam; later, they cost the kennelman an unnecessary feeding bill, which must surely appear in the price asked for the puppy. For an owner two months is a good age; eight months is better, and a year and two months is the ideal age to buy.

For some time I tried to buy first-class pups a year old and over distemper. "There ain't no sech animile"; all the best of every litter have been sold by that time, and you will either get a runt or one with some defect which every one else has seen and avoided. I have come to depend upon Pasteur's serum to protect my pups during 
the trying months from May to July when distemper is on every urinal tree and post. The kennelmen usually shoot in an injection and also clear the dog of worms just before shipping, but occasionally they omit it or get a lot of non-active serum, so your safest course is to get a hypodermic syringe $(\$ 2.50)$ and a dose of fresh serum (75c.) and shoot two cubic centimetres under the skin of each hind leg, inside the thigh or else into the folds of skin behind the fore-shoulder. This will immunise him for two months and will save a dog that has already been exposed to the disease but has not yet come down with it. You can get the outfit through your druggist. In the fall give him another dose, and again next spring, when he will be over a year old and much more able to withstand an attack of distemper. It is a terrible disease; two out of every five bird-dogs and hounds that get it in puppyhood die of it; down in South Carolina, where I was quail shooting this year, they had a veritable scourge of it, many hunters losing nine and ten dogs in two weeks' time. Mongrels, because of their many outcrosses, get easy cases of it; but thoroughbreds, which are constitutionally weaker through inbreeding and line breeding, always take it hard. The first sign is a large yellow pustule or several 
of them on the belly between the thighs, and a mattery discharge from eyes and nose. Then is the time to get busy with your serum, which will help lighten his case, and, if it is of the cough-andcold variety, dose with the patent preparations on the market; if intestinal, give bismuth pellets and a fever medicine like sweet spirits of nitre, fifteen drops in a half cup of water, half a teaspoonful being poured down the dog's throat by holding his muzzle shut and pulling out his cheek pouch and pouring the liquid down the funnel thus formed. The treatment of this type of distemper is in general like typhoid in a human; little to eat, absolute quiet, and fever medicine when he goes over $103^{\circ}$.

But, by keeping your puppy away from other dogs during the spring, never letting him walk with you into town or anywhere where he is likely to smell the "sign" of other dogs, and never letting him get a severe chill, you can get him through his first spring without distemper and have a good chance of raising him to maturity. 


\section{CHAPTER VII}

\section{KENNEL CONSTRUCTION}

IT is wonderful how some time-honoured designs persist, regardless of their logical fitness for the purpose intended. People copy and copy, generation after generation, without ever once giving a thought to possibly getting up something better. One of these time-honoured traditions is the dog kennel. Every one has seen one and carries with him a mental picture of how one looks. Perhaps our childhood readers and story books are responsible for the persistency of this design. We can all recall the pictures of Fido's kennel, and to even suggest to any man that he does not know how to build one would be to call down wrath and scorn on the daring heretic's head. We all know how a kennel looks-a sort of tiny gable house, with a large round hole in one end. It is the accepted design, and, alas! the worst one that could be devised, if you asked dumb Fido's opinion about it. That round door hole in the front!

-how many rheumatic spots and liver chills has 


\section{KENNEL CONSTRUCTION}

it inflicted upon the poor dog, when the wind happens to be blowing into the mouth of the kennel! Put in a curtain with a sanded hem, how long will it stay there, and how soon will it be repaired when once rent and torn? Those dark dirty corners, unreachable to clean properly, forever unvisited by the sun's germ-killing rays, forever a breeding place for hordes of fleas-how many dead and miserable pets are chargeable to them alone! And once Fido learns that his kennel is a place to which he can bolt to escape punishment, from which he can neither be dislodged nor coaxed, how long can you maintain discipline over him! And then in summer-did you ever try to sleep in a closed tent in midsummer, with a small door the only opening? recall it, once, and then picture to yourself what a suffocating hot-box that kennel is and will be, far into a hot summer night!

No; we must give our kennel far more thought than that. It costs just the same in boards, nails, time and tar paper to build a rotten kennel as to build a fine, sanitary, sensible one, wherefore, in the name of common sense, let's have a good one! Did it ever occur to you to turn the kennel sideways, close up the ends tight, and put the door in the side, at one end, as a possible improvement? If your bed is around the corner, as it were, there 


\section{THE AMERICAN HUNTING DOG}

is no objection to a wide opening to let in fresh air at the far end, so long as you have a comfortable, wind-tight and draught-proof retreat beyond the door to curl up in. That's the way Fido would look at it, if you asked him! And then, from your human point of view, that of being able to clean the kennel easily, why not have the rest of that side hinged at the top, so that it can be opened up to expose the whole interior for cleaning, and also in summer permit raising it up to keep the kennel cool and provide a verandah under which the dog can lie if he finds his bed too hot. And so we get Ideal Construction No. 1, videlicet, a side-opening kennel, with the door at the end of said side, and the rest of the said side openable from hinges placed up under the eaves. How large? Measure your dog, some time when he is lying flat on his side at complete ease, his legs stretched out straight as if in walking posture. For a setter, pointer or coonhound this will be found to be about $24 \times 36$; for a smaller dog, such as a beagle or spaniel, 20x28. With this basis of floor area to go on we have but to decide on the height to be ready for the work of building. The bird-dogs and large hounds stand 24 inches at the shoulders, and, so that the kennel may be warm in winter, we will make it not much higher 


\section{KENNEL CONSTRUCTION}

than required to stand up in when preparing to curl up. Thirty inches is plenty, and the lean-to is preferable to a gable as being easier to keep tight, warmer in winter, and more sightly about the place.

Such a kennel can be built out of a shoe packing box, which one can get from the shoe store for perhaps fifty cents, but it is a poor, flimsy thing, and in time the boards will swell open, making cracks which do more to make your dog rheumatic than any other thing, unless it is that end door centrally located which $I$ have protested against before. Why not order some tongue and groove $7 / 8 \times 8$ inches pine ceiling, and make a regular job of it? Five 12-foot boards of this ceiling will be enough, and $\$ 2$ will buy the lumber,-little enough to spend on the housing of a valuable hunting dog! For corner posts a 12 -foot piece of $2 \times 2$ hard pine will be enough, and for nails a pound of 8-d. will be about right.

To build, you first make the two ends. These require three boards, 2 feet long, and one board two feet long drawn diagonally across to make the two slants. Cut two posts 32 inches long, and two 40 inches long, for back and front posts, respectively. This will give you eight-inch legs for the kennel, the back being 24 inches high and the front 
118 THE AMERICAN HUNTING DOG

32. Nail the side boards and the slants to these posts, making them flush with the posts. As one slant will have a tongue and the other groove, you will have to watch out for this in knocking together the two ends, so that the tongues are up at one end, and the grooves up at the other. The next thing to go on is the back-three boards 36 inches long and nailed to the ends and their posts. A lintel is now needed, joining the two upper front corners, and this is simply the uppermost board of the front, 36 inches long, and nailed across the ends and posts. You are then ready for the roof, which is made of five boards 36 inches long, overhanging front and back 6 inches, and at the ends 2 inches each. The kennel can now be set up in its permanent location, and this is best with a south exposure to the front, and its back protected against north breezes by barn or house corner, or the back fence will do if not of pickets.

To finish the front you first need a post, put in from the left-over two-inch stock. The dog door will do nicely if ten inches wide by 16 inches high, for even a very large dog can easily squirm through such an opening, and there is no sense in making it large enough to walk through at full height like a house door. The post is then put in with its edge ten inches from the left hand end of 


\section{KENNEL CONSTRUCTION}

the kennel, and a hinged side, three boards high, 26 inches long, is cut and nailed to two cleats. A pair of hinges is then put on across the crack, between this door and the upper front board, and a fastening of some sort is devised to hold it tight at the bottom, and the kennel is built. It will need a roofing of a piece of tar paper running well over the ends of the roof boards, and secured with the usual tin washers. The whole job is then given $\Omega$ coat of paint, and you have a durable, practical, warm and windproof kennel. Two fittings will be needed, a bed of straw, sewn up in denim or duck ticking to form a mat 24 " $\times 36$ ", and a resting bench 24 " $\times 36$ " made of two strips of 2 " $\times 4$ " set on edge, with slats 36 inches long nailed across them, leaving a space of some half an inch between slats. This bench is more necessary than it seems at first sight. It is high and dry and self-draining, and is for the dog to lie on in the sun when the ground is still too damp and cold to be healthy. In the early spring and late fall there will be many days of this sort, the same that make for colds and malaria among us humans, if we sit on the damp ground. The dog will lie on the cold lawn or the driveway in such days and make himself sick or pave the way for an attack of distemper if no suitable raised bench is provided for him, for, of 
course, he does not want to seclude himself in the kennel during the day. Then is the time he wants to be up and doing, barking at passers-by, handy for a pet or a caress from his master or the children, and generally "in" everything. If he is a hunting dog then is the time he must be tied up according to the laws of many States, and it is up to his owner to provide him with a suitable resting place. The straw mattress also commends itself without argument as much preferable to plain straw, for the mattress can be taken out and aired and sunned every day, while the straw bed can neither be aired nor cleaned, and, therefore, becomes a breeding place for fleas (for they do not breed on the animal himself). To get such a mattress either into or out of the ordinary kennel, with its one opening in the end, is impossible, and, therefore, the mattress itself is one of the most powerful arguments for abandoning such a kennel in favour of one whose whole side can be opened on hinges.

In view of the low cost of this kennel we shall not waste much space in discussing the oil-barrel kennel, which costs about as much to buy, and has all the disadvantages of the box kennel, besides being too small for hunting dogs to stretch out in when lying on their side. 


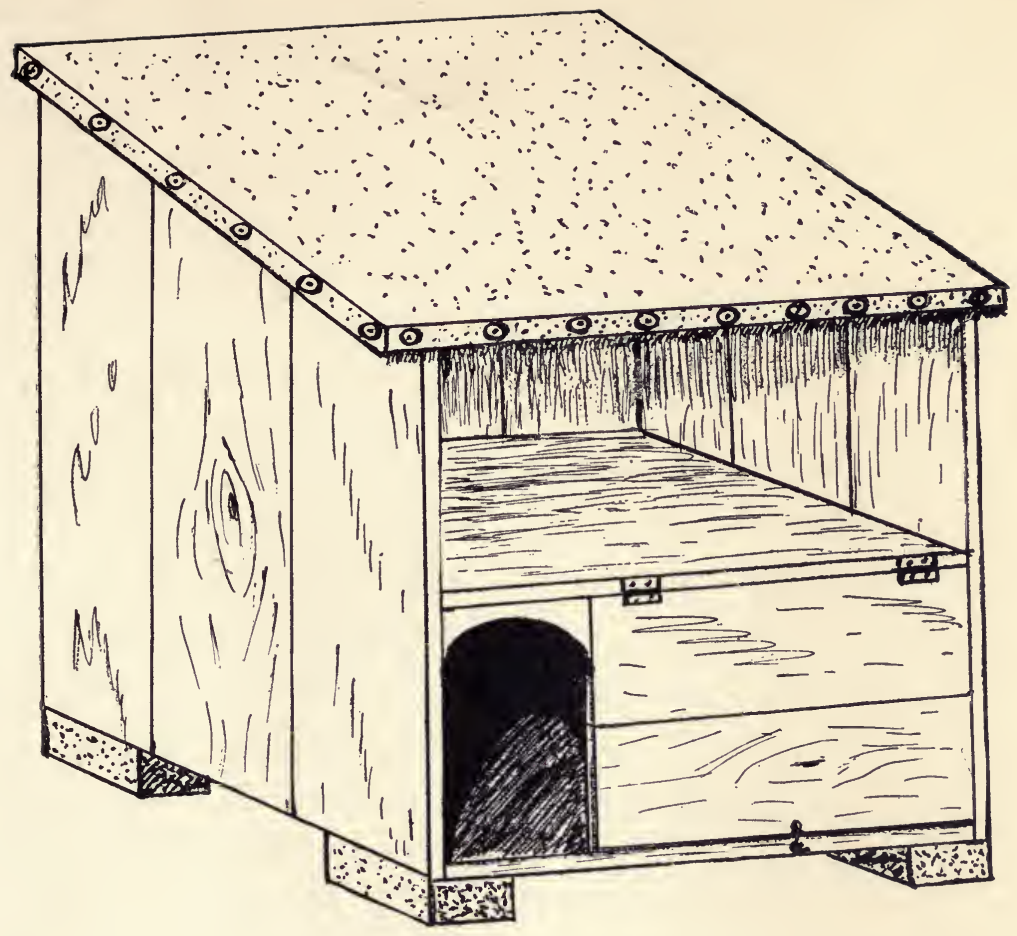




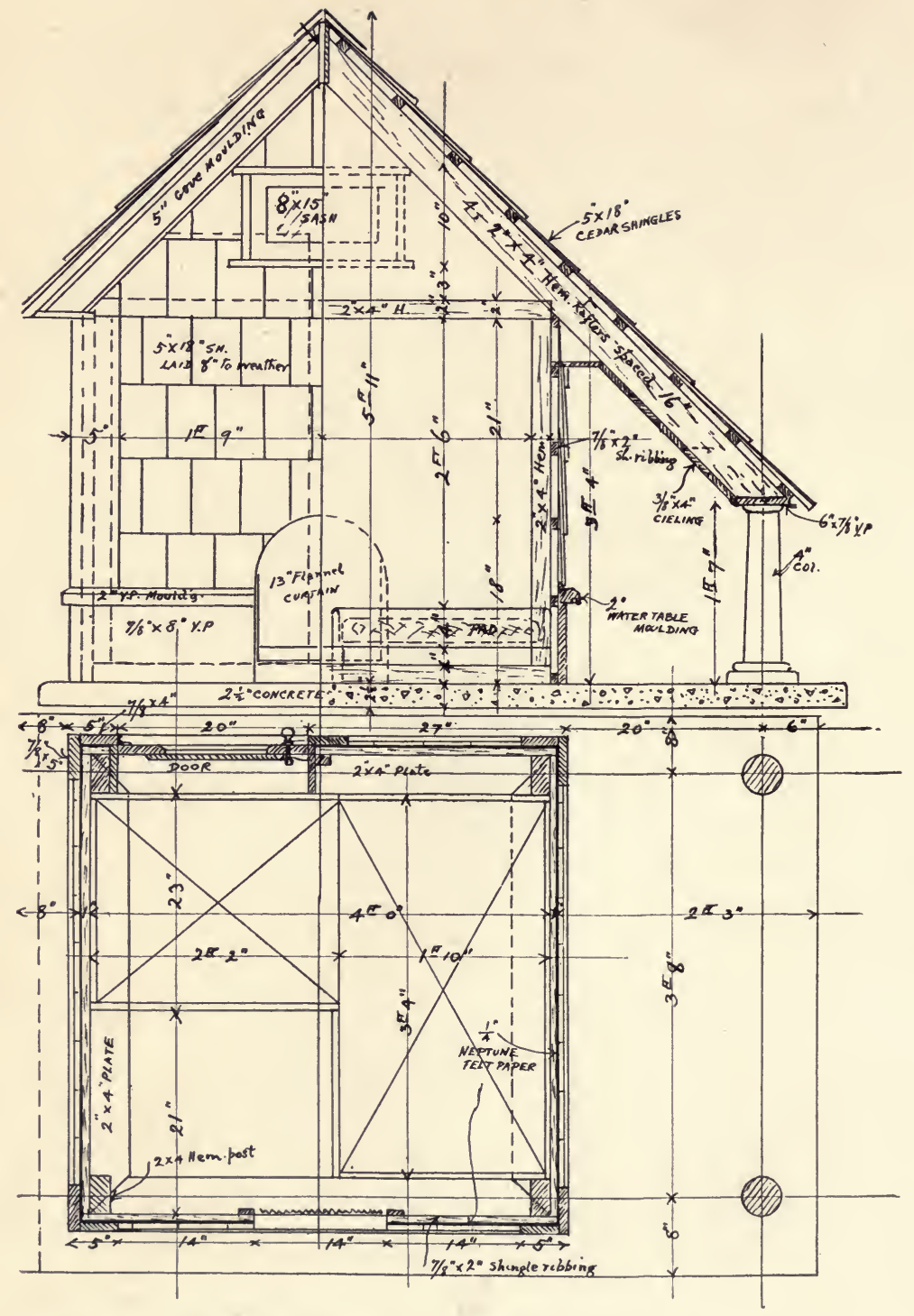




\section{KENNEL CONSTRUCTION}

For two or more hunting dogs, I published in my book, "Airedale, Setter and Hound," a design which has so many of the required points of an ideal two-dog kennel that it will bear repetition here. A kennel big enough for two 60-pound hunting dogs should be big enough also for a man to enter and clean. This kennel is a permanent, handsome structure, with concrete floor and runway yard, an ornament to any country place, and just what the passer-by would expect to see if the owner keeps dogs. Its cost for materials is about $\$ 20$ (probably $\$ 25$ at present lumber prices), and the labour on it would be about $\$ 6$ if you did not do it yourself. The kennel has shingle roof and sides, a well-shaped bunk to accommodate two hunting dogs, a porch for hot weather, and a cinder or brick floored yard. The designs herewith show its appearance and detailed construction, and the lumber list will give you the stock needful to be ordered. The body of the kennel is $4 \times 4$ feet, and height to the peak, 6 feet. The roof beams are carried on down at the front to make a porch about 2 feet wide, running across the side of the kennel and facing preferably south. To begin with, a $7 \mathrm{ft}$. $\times 5 \mathrm{ft}$. floor of concrete $2 \frac{1}{2}$ inches thick is laid down, and, while soft, the bottom plate frame of $2 " x 4^{\prime \prime}$ hemlock is set in place on wooden 
122 THE AMERICAN HUNTING DOG

pegs going down into the concrete. When this hardens (if a nail will not scratch it it is set) you toe-nail on the corner posts and the top frame, after which the edifice is squared and held so by diagonals while you cut and fit on the rafters. The shingle ribbing goes on next, spaced the same distance apart as the shingles are to be laid to the weather, 8 inches. The roof shingles are then put on, beginning with the double bottom course and laying up half a shingle less each course, so that if you have to quit work at any time none will be totally exposed to the sun or rain and be warped. It takes a day's work to shingle this roof. Next you start covering the body of the kennel. As its sole heat will be the warmth given out by the bodies of the dogs it is well to conserve this in winter by getting some insulated hair felt refrigerator car lining and wrapping it on over the shingle ribbing, tacking it flat here and there. Next goes on the trim, the corner finish and water table and then you are ready for the body shingles which are laid the same as the roof. An inside sheathing of $3 / 8$-inch tongue-and-groove wainscoting will make the kennel still warmer in winter and cooler in summer. This is not essential, however, and robs one of 5 inches of inside room all around.

Concrete makes a poor floor for dogs to lie on, 


\section{KENNEL CONSTRUCTION}

for it is unmercifully cold. The only proper berth is a low wooden bunk with 4-inch rail and a mattress laid in it. This bunk must not be so high off the floor that it will let a dog crawl under it: 4 inches high is plenty. If made in an ell for two dogs, of the dimensions given in the plan, it will permit them to curl up together on cold nights and lie apart on warm ones. The partition between the two bunks across the ell should, of course, be omitted and the bottom board match up fairly. The bottoms should also be of tongue-and-groove stock, so as to prevent air cracks.

For a yard for both this kennel and the smaller one first described, a covered runway will be the most economical scheme. The four main posts of the yard need to be set down at least 2 feet, and a trench dug from one post to the next. Stout square-mesh chicken wire is then run from post to post and the earth tamped back. Foot boards are then run outside the posts and the mesh coming out of the ground is tacked to these with staples. A top rail is run around the top of the posts-about 4 feet high is good enough-and the wire fencing staple from running board to top rail. Any one of the heavy wire farm fencings will do, and if puppies are to be kept in the yard it must be reinforced 2 feet up with chicken wire. The 
top covering may be of chicken wire in any case.

Such a yard is far preferable to a chain, or a wire with ring and chain. The plain chain keeps the dog too confined, and is forever getting him wound up around something; the wire runway with ring and short chain I never found much better approved of by my canine dependents, for they would always sit down and bark, at the end of the contrivance nearest the house, seldom utilising its possibilities for exercise. But the yard permits free, if limited, roaming, and a pair of dogs will always get a lot of exercise, wrestling with each other, even in the narrow confines of the yard. Dogs form strong friendships among themselves, and a pair of them will keep each other in good condition, wrestling and pretending to chew each other, off and on, all day, varying the exercise by periods of sleeping in the sun. And the yard is the only solution of the wandering and adventurous puppy problem. If you have a brood matron instead of a pair of hunting dogs, this kennel and its yard will be of the best design for rearing litters of pups.

As accessories, the yard will want three things: a resting bench; a roost made of straw piled up on some elevation like a packing box upon which they can jump up to or down from; and a urinal 
post put in about the centre of the yard. This latter will be well patronised according to the dog's nature to hoist his leg, and will save much soiled fencing. After a case of distemper, dig up the post and put in a new one.

For larger kennel operations, such as keeping hound packs and dog breeding, the kennel becomes a house partitioned into several of them. For summer undoubtedly the healthiest scheme is a set of outlying small kennels, each located in its own patch of field. The combination of a peach or other fruit orchard with such a kennel proposition is a good one, about thirty brood matrons and a few classy sires, in combination with a tenacre orchard being about all one man could manage for a year-around business. Some day I may start such a proposition myself on a southern plantation, as the need for a large kennel in the East, supplying good bird-dog pups at reasonable prices is so great that all the pups raised could be marketed with very little advertising. After the cultivating season is over the dogs are moved out of winter quarters and kept in separate kennels, with suitable fencing to avoid fights and mixing of puppies. It is quite as wholesome a way to raise them as putting the puppies out to walk at neighbouring farms, as is often done by large 
breeders. These outlying kennels would, of course, be identical in design with the one-dog kennel described above, except that for nursing mothers a whelping-box would be needed, that is, a shallow sleeping box with an inner rim around the edge of $7 / 8$-inch $\times 3$-inch stock, forming a sort of refuge for pups that have fallen in behind the mother's back, and would likely be crushed without some such gallery to protect them.

But for warmth and compactness in winter the kennel house is needful. This will have three or more $6 \times 8$-foot pens, for dogs and bitches not in season, an 8-foot $\times 8$-foot room for bitches in whelp or in heat, a puppy room of the same size, and a large 8-foot $\times 16$-foot room for cooking and storage. A small steam boiler, similar to those used for greenhouses, answers for cooking operations in the daytime and at night is switched onto the hotwater piping of the kennels, as a very moderate amount of heat is well worth while in mid-winter, and is particularly necessary in the puppy and whelping-rooms. The great problems of successful kennel management are, cheap wholesome food and isolation of disease. No dog can get distemper without smelling or touching something already contaminated by a dog that has had it. Each of the main rooms of the kennel house lead 
out to a yard or runway, built like the one described for the two-dog kennel, the larger the better, and the healthy dogs in them are in no danger, provided the hospital is isolated from the rest of the kennel, and any dog showing any suspicious symptoms removed to it at once. Distemper is the great contagious disease, and, aside from prompt treatment with antitoxine serum, I hold that dry quarters and fresh air with no artificial heat makes the best condition favourable to recovery. It is essentially a spring disease, and is most rife in April and May when no heat is wanted, whence there is no objection to isolating the hospital as far as possible from the main kennel.

But cooking operations are another matter. They must be carried on on a large scale, without danger of scorching, whence the use of steam in a worm surrounding a large boiler. The best ingredients are cornmeal, wheat bran and restaurant meat scraps with bones. These are mixed and boiled soft in the boiler, and then baked in pans in the kennel oven, the harder the better. The oven is best a flue attachment of the heater so that one charge of anthracite does for all, instead of two fires, each with its own inevitable waste of partly burned coal, to which all small fires are prone. Each dog will need two half-pound cakes 


\section{THE AMERICAN HUNTING DOG}

of the biscuit a day, and the puppies thrive on the mash added to broken up stale bread baked to a golden brown in the oven. The boiling of mash goes on throughout the day, and the batches of cakes are at the same time being turned out from the oven, so that, aside from the cost of the raw material, there is little waste in the food account if the cook room is properly run.

This kennel house may be built of clap-boarding, with refrigerator felt lining underneath, or the latter omitted and a ceiling nailed across the studding inside. The panels between rooms are of plain tongue-and-groove ceiling. The roof is of induroid or rubberoid paper on pine sheathing, with a pitch of about 1:6. The framework is of the usual $2 \times 4$ studding and $2 \times 6$ ceiling beams. The floor is of $7 / 8$ " matched yellow-pine flooring on $2 \times 6$ sills, spaced $16^{\prime \prime}$ and set a few inches above the soil. Any carpenter can design the details of this kennel, given the dimensions, and any one at all familiar with tools can build one himself from his own plans, with the hints given above. 


\section{CHAPTER VIII}

\section{DUE. TRAINING}

\section{FUNDAMENTALS}

THE foundation of all dog training is obedience. Hunting is in no sense play, but work, for the dog. He may like it, as the soldier does campaigning, but the essential foundations of discipline and obedience are there just the same.

To this end all dog training, from the simplest order to the most complicated manœuvre, has for its basis command and enforced obedience. The best instrument for this is not the strap, but the force collar. This is a collar with a tongueless buckle, armed inside with blunt spikes, which, while in no way injuring the dog's skin or coat, have the power to punish him when the cord attached to the end of the collar is pulled. A plain collar is ineffective, for, while it restrains the dog, it does not punish him. A strap is impractical for it frightens the dog to be whipped and he is not likely to understand what he is being whipped for. 
A dog's mentality is so limited that he does not grasp the meaning of most words, so that each command must be reduced to its most elemental meaning before the dog can learn what it is that you want. For example, the command "Fetch!" means nothing to your dog. The word "fetch" means to go and get something and bring it to you-an entirely too complicated idea for the dog to get out of one word. To him it is just another queer sound, and he hasn't the least idea what you want. He must, therefore, be led up to the idea "Fetch!" by a progressive series of lessons.

\section{LESSON I.-SIT DOWN}

After your puppy, through constant feeding and companionship, has gotten to the point where he adores you, has every confidence in you and will do anything in the world to please you, he is ready, at about six months of age, to begin his course of field training. Buy a force collar, and then lead him to a quiet room or spot where interruptions and distractions will be infrequent, and put on the collar, with short leader attached. He may revolt at it and fight, but keep quiet, speak calmly and kindly to him, letting him fight it out with the collar until he realises that the only way it will not hurt him is when he remains quietly 
passive to your will at the command "Keep still!" Next, command "Sit down!" at the same time forcing his hind quarters to a sitting posture. Keep him there a few minutes, pet and repeat the lesson, using the collar punishment only if necessary. About five repetitions will suffice to make him sit down at command, and a cautioning finger will keep him there while you walk around him at increasing distances. At the end of each trial; command "Up!" snapping your fingers and getting him up to come to you for a petting, praise, and a reward of a bit of dog biscuit. This lesson is enough for the first few days and no lesson should extend over half an hour at a time.

\section{LESSON II.-FETCH}

Command "Sit down!" Have with you a corn cob. Present it to his mouth, commanding "Fetch!" sharply. Open his mouth, instantly inserting the cob, and, holding his mouth closed, command "Hold it!" Release your hand and make him hold the cob. If inattentive or inclined to drop the cob, use the force collar, which should be on him all through the lesson. He will open his mouth to yell, when you pull the collar and you at once insert the cob.

After holding a brief while, command "Give 
up!" and take away the cob. Pet, praise, reward, and repeat the lesson. He will soon get so he will reach for the cob with his mouth and snap for it at the command "Fetch!" This is what you are waiting for. Hold it further and further away at each repetition, finally dropping it and commanding "Up! Fetch!" Then drop it a yard away; two yards; throw it a short distance and praise and pet him each time he fetches it. You now intersperse the command "Fetch!" with "Dead!-Seek dead bird!" until he realises that the two commands mean the same thing. After a week of "Fetch!" he will get so you can drop the cob any time and he will look for it until found and bring it to you.

\section{LESSON MI.-STAUNCHNESS}

If your dog is of good hunting stock he will notice and point birds at about three months. The tendency to break and chase is very strong and he should wear the force collar when afield as soon as his training lessons begin. When he draws up on a bird, call "Steady!" to calm him, and if he starts to break and flush, call "To Ho!" and pull sharply on the cord. The grip of the force collar reminds him that you still have power to punish him. In the same way the tendency to chase small 
birds, swallows, etc., should be checked at once unless the dog is so backward as to need his hunting instincts aroused. After your dog is at large (with the force collar still on him) you had best take along an air rifle and sting him with it if he disobeys any commands to come to you or stop chasing birds. In working on birds, thirty feet of cord and the force collar are essential, to check flushing and breaking shot when the covey rises. Teach quartering and ranging in the same way, using a dog whistle to call attention each time you change course, waving your hand and walking with him in the direction you wish to quarter until he gets the idea.

\section{LESSON IV.-GUN-SHYNESS}

No dog likes the gun at first. If of good hunting stock he will not be naturally gun-shy and your only care will be not to overdo at first. Only one gun and one barrel to the covey, until he gets the idea that the gun is part of the game and is meant to kill birds with. Some dogs, particularly hounds, are naturally gun-shy and must be introduced to the gun with much caution. I am not in favour of promiscuous shooting in the hope the dog will like it. Better try first the excitement of actual hunting. If the dog then proves gun-shy 
134 THE AMERICAN HUNTING DOG

(and lots of them do), he must be taken in hand and broken of it by the starvation method. Tie dog to kennel. Do not feed for 24 hours. Bring out gun and plate of food. Put food near dog and fire gun. If he bolts back to his kennel take food away. If not, but keeps on eating, keep on firing while meal lasts. Come again a few hours later and offer food again, firing gun. The most stubborn case will be broken in a week of gun and meal and the dog not only learns that there is nothing to be scared of in gun-fire but also that he must not be afraid of it or else lose his dinner.

The above methods of force training were developed by Mr. E. F. Haberlein, the famous dog trainer, who has broken over thirty thousand dogs. I have used them on all of mine, after trying a great variety of other methods, and I have no confidence in any other. I can endorse the force method as sure and based on sound principles of absolute unquestioning obedience and the power to enforce your commands. Like drill in the Army, it is the only way to really train a dog.

The following questions and answers on dog training and hygiene are selected from thousands asked me during my many years as editor of Field and Stream, and they cover many points met by dog owners in actual work afield. To me they 


\section{DOG TRAINING}

seem more practical and interesting than any mere academic discussion of the subject.

\section{FORCE COLLAR}

Would you please send me information regarding E. F. Haberlein's force collar? Have a dog that breaks shot and think it will stop him.

\section{Albert G. Teachman.}

Ans.-This collar is of black leather with tongueless buckle, and is reversible. It is armed inside with four blunt steel stubs, and will cure him of breaking shot.

\section{SOME SETTER QUESTIONS}

I have recently purchased what is supposed to be a Llewellin setter, and a thoroughbred, although I have not yet received the proper documents to confirm this.

Now what I desire to know is: What are the markings or description of the Llewellin? The party I purchased from advertised the dogs as being pure white with black ears, running down chops, with black ticks, but upon receiving the pup I find that he has misrepresented as far as the description is concerned, for the dog is white with yellow ears, and a few yellow spots over hind quarters. The pup is very thin; in fact, his bones 
136 THE AMERICAN HUNTING DOG

almost protrude through his skin. Is a barn too cold to keep this dog in, and what should I feed him during the winter, or at all times? He is a September pup.

As I am not in a position to keep a dog at the place I reside I leave him with a farmer out in the country, who is going to keep the dog until spring, when, of course, I will be able to take him back and keep him tied in the yard. The man who is taking care of the pup has children, who play with him every time they go to the barn. Do you think that this will spoil the pup? And would it be advisable for me to keep the pup with me at all times in order to get good results for next season's hunting; that is, if the dog can be trained to hunt birds? He is continually scratching himself with his hind paws. Is that not a sign of lice?

At what age can I start him hunting chickens? Should I keep him tied up? Where should I send the pedigree to have it registered? Could I train him both for woods and field hunting and get good results on partridge and prairie chickens?

What are the markings of a thoroughbred pointer and cocker spaniel? And are they a good dog on partridge?

R. F. EBNER. 
Ans.-Answering your various dog questions, would say that, until we have received the pedigree, there is no way for us to judge whether he is a thoroughbred Llewellin or not. The markings of the Llewellin vary all the way from the pure white with a very little orange, to the darkest Blue Belton, depending a good deal upon whether he is of Whitestone, Gladstone, Antonio, Uncle Bob, etc., extraction. We would advise your feeding him up this winter, and enclose our standard dog diet herewith.

Except in very cold spells, the barn is just right for a place to house him.

The more exercise he gets with the farmer's children the better. It will not do him any harm as a pup, as this winter is the time he should get his growth.

Regarding scratching, we would suggest your washing him all over with a solution of Boving's or Glover's Eczema Cure, which will rid him of any skin irritant, lice, fleas, etc., with which he may be afflicted. He may be coming down with eczema from improper feeding, in which case our dog diet will set him right again.

You will be able to work him on chickens according to the Minnesota law, about next August (as we recall it), and later take him hunting when 
the season opens up. I would not keep him tied up until next spring, when the law requires it.

Regarding pedigree, same should be sent to the Field Dog Stud Book, care American Field, Monadnock Block, Chicago, Ill.

To train him on both partridge and prairie chickens is rather difficult, as partridge require a close, careful dog, whereas chickens and quail will do better with a wide ranging dog.

There are no standard markings of either pointer or cocker spaniel. The latter makes a very good dog on partridge.

\section{BREAKING A PUP WITHOUT OLDER DOG}

Would it be hard to break a pointer or setter pup on quail or pheasants without using him with a trained dog? How would you go about it? Which would be easier, pointer or setter?

R. M. Chapman.

Ans.-I do not think it makes very much difference whether an older dog is present or not when you are training either pointer or setter on quail. The dog has to be taught by experience, and, if he has the natural pointing instincts, your first troubles will be breaking shot, flushing birds, failing to show perseverance in hunting for grassed 


\section{DOG TRAINING}

birds, and sometimes gun-shyness. All these faults can be trained out sometimes by command, scoldings, strappings, etc., and sometimes by the use of the force collar. A good course of yard training is a great help, but practical field experience, coupled with accustoming the dog to implicit obedience, is the best school.

\section{"DROPPER"}

I own a handsome, lively bird-dog puppy six months of age, whose dam and sire were both excellent field dogs. However, his breeding is half English setter and half pointer, and therefore one of my friends calls him a dropper and says he is by no means likely to turn out well. Will you tell me whether or not that opinion is well founded?

I have been reading "Airedale, Setter and Hound" with interest. My dog learned to sit down and to charge very quickly, but I have had little success in teaching him to retrieve. I have tried at least forty times in all to get him to take the pad at the word "fetch," but he seldom does it without having his lip pinched. He just stubbornly shuts his eyes and remains inattentive. Would it be advisable to use the force collar with him?

Wm. W. Allen. 
Ans.-The cross of setter and pointer is called "dropper." If both dam and sire have been good, active workers afield on birds, the offspring, as a rule, make fairly good workers, too; but for future breeding the dropper is worthless. The time required to train a dropper will be fully as much as taken up by a thoroughbred, one who, when trained, commands a price, if desired to be sold; while a dropper seldom gets an offer at anything near the former.

Retrieving.- "Would it be advisable to use the force collar with him?" The question is also the answer. "Shuts his eyes and remains inattentive" - that's it, exactly. By use of force collar he will be made to open his eyes and take notice suddenly-in fifteen minutes he will fairly snap at object to grab it to prevent punishment and henceforth obey promptly at the word.

\section{A CURE FOR BOLTING AND CHASING}

What course would you advise me to follow with a setter pup not quite a year old that is hardheaded, takes a switching good-naturedly and soon forgets it? He points, backs, stands and hunts cripples and singles in fne shape, does not flush any birds. Only he will run and race and does not come in when you call him nor slow down any 


\section{DOG TRAINING}

unless you almost holler your head off. He does not know me yet, as I just bought him.

\section{Edwin B. Kelley, JR.}

Ans.-You had best purchase a force collar.

Take the dog out afield with about thirty feet of cord and force collar on and break him of running away by stepping on the force collar leader every time he shows a tendency to bolt. Then when he starts, shout "To Ho!" just before the force collar fetches him up. He will soon learn that "To Hò!" is not to be disobeyed. If he gets out of hand do not shout at him, for it simply shows him you have no real command over him.

I would advise commencing this treatment promptly, before this dog gets into the habit of chasing and disobeying your commands.

\section{GUN-SHY DOG}

I have a setter dog fifteen months old, just received from trainer, November 10.

$\mathrm{He}$ is well bred, has an excellent nose, staunch, finds and handles birds in a workmanlike manner.

Have gunned him three days and each day he seems to get more nervous.

The first day he would come to heel after shots were fired, but after a time would go out and hunt 


\section{THE AMERICAN HUNTING DOG}

again. Yesterday after the first shot he would not hunt at all.

Each time the old dog would stand and there were indications of shooting, he would crouch close to the ground and tremble, and could not be induced to back old dog's point.

He will not leave and is not afraid of the gun only when you assume a position to fire.

He has always been nervous and high strung. I am at loss what to do, for without a gun he handles birds like a veteran.

If you could suggest anything which would correct this fault I would be a thousand times obliged.

Harold B. Davies.

Ans.-From your letter it seems to me that your dog is not naturally gun-shy, but has been forced by his trainer to remain staunch during gun fire. $\mathrm{He}$ is clearly afraid, and like some hounds that I have owned is inclined not to hunt when there is a gun around. I doubt if you can break him this season of it.

Keep him out with you-if necessary on force collar and leader. I think you will have to put a day in occasionally without shells in the gun until he gets his confidence, using either just primers alone or little loads which would not make 


\section{DOG TRAINING}

much report. This is asking a good deal of a man to do in the middle of the quail season, but once a dog gets gun-shy he is very hard to break. If he still persists, put him through the course of cure by starvation.

\section{BREARING A DOG OF MOUTHING THE BIRD}

I have a young pointer bitch which is about eight months old. She is a good worker, but she has one fault. When told to "Fetch!" she always chews the bird, and some time before she gets to you she has eaten the bird up. I would like you to tell me if you can how to break her of this habit.

I have stopped hunting with her on that account.

S. J. Bartell.

Ans.-Get to bird as quick as you can. Take from her and beat her severely. Make her "fetch" it again, and if she chews whip and scold her and take bird from her. Make her fetch same bird again and again until she will bring it without daring to mouth it. Another way is to prepare a dead bird with pins inside, replace skin and then make her fetch it until she no longer bites it. Bird should be held firmly in mouth, not picked up by one wing. 
I have a pointer dog, excellently bred, about three years old, which I have hunted a good bit on partridge. He comes of a strain of quail dogs and has the hunting instinct almost to a fault, points very tensely, retrieves, etc., very intelligent (much above the average), is a fine companion and well house-broken, but is altogether too fast for grouse hunting, flushing his birds almost as soon as he gets scent and seemingly enjoying it. I have tried force collars, ropes, etc., and even got a sort of harness to hold him to a trot, but all to no purpose.

\section{H. C. Murray, M.D.}

Ans.-I think you are "up against" a pretty severe proposition. A dog that is used to quail and a fast ranger is pretty "sot in his ways," and what you want is the exact opposite-a dog that is quiet and cat-like in his hunting and with a keen nose for the faint scent of a single grouse. I would be inclined to trade him, if I were you, for a good grouse dog, preferably a Laverack Setter of one of the well-known grouse strains. I doubt whether any trainer can make over this dog without ruining him as a field dog. 


\section{DOG TRAINING}

HARD MOUTH IN POINTERS

A friend of mine has a pointer, which during the present hunting season has developed a very hard mouth. Can you inform me whether or not this fault can be corrected, and how? The dog is five years old, and is a grand worker. Until this season his retrieving has been of that brand which leaves nothing to be desired. It began by his mouthing wounded birds. He was scolded for that, but not punished. The fault developed rapidly, until at the present time he can be depended on to practically ruin the great majority of his birds. An attempt is being made to correct the fault by the force system, by which he was trained, but up to the present time the results have been negative. Any suggestions will be greatly appreciated, both by my friend and myself.

\section{DR. H. S. RoBINSON.}

Ans.-We usually cure hard mouths in our pointers and setters by beating them severely the instant they mouth a bird. Then hand the bird to the dog again, and he will usually bite for it, and then give him another licking. About the third time he will be afraid to touch it, and then 
you can lay a feather of the bird across his nose and he won't touch it.

We cured old Jack of this in a week, although it was mighty hard quail shooting, as we had to beat him to the birds for it.

Making a dummy with pins inside is often advocated, but I think the lessons must be given with a freshly killed bird to be effective.

\section{YELPING ON TRAII}

Please advise me of the best way to break a hound dog of whining and yelping when he is kept in his run, other than whipping.

Ans.-Regarding breaking a hound dog of whining and yelping, would say we do not believe it can be done, as it is in the instinct of the dog and we see no particular advantage in not having him give voice on the trail. The only mute hounds that we know of are crosses with shepherds or other stock.

\section{CURE FOR BREAKING SHOT}

I have a setter I got in Georgia, and while he has a fine nose and is a grand ranger and very staunch on points, he has never been broke to charge and will break shot. $\mathrm{He}$ is a year and six 
months of age. Can you give me a tip on how to remedy these faults? He will not stand whipping, but is very high strung and looks well bred.

\section{LeRoy BennetT.}

Ans.-Buy a force collar and steel tent peg. When dog comes to point, snap a 30-foot leader to force collar buckle and peg down other end. Flush birds and shoot. If dog rushes in yell "Charge!" - peg and leader will do the rest. A few repetitions will cure him of the tendency to break shot. Haberlein's force collar is a good one and not cruel. Whipping will do no good whatever.

\section{BIRD FLUSHER}

Please tell me the best way to break a dog that is 18 months old of wilful flushing of birds.

The dog is thoroughly broken in every other respect but flushes, and would you advise whipping, or what methods would you take?

Kindly let me know as soon as possible, as I have a fine young setter that even retrieves nicely but flushes every point.

J. Leon Cole.

Ans.-Regarding breaking a dog of flushing: at 18 months he will do it a good deal if allowed to 
148 THE AMERICAN HUNTING DOG chase when a puppy, but will get over it in his second year.

FLUSHING IRISH SETTER

I have an Irish setter three years old, beautiful hunter, but fails to stop on the birds; has a tendency to flush the birds and then trail them like a rabbit hound. In all other ways dog acts beautifully. Can you advise me what to do in the matter?

R. Russelt Robinson.

Ans.-The best cure for your dog would be to buy a force collar and check cord and then train her not to flush according to directions given in elements of dog training.

\section{BREAKING A FLUSHER}

I have a Llewellin setter dog, five years old, which I just bought from a man in whom I have great confidence.

I had never seen the dog till he arrived (November 1st), and the next Saturday and Sunday I took him out to give him a trial. At first he chased a few rabbits, but I soon broke him of that. Then he flushed three birds. Finally he got the scent of the place from which the last bird got up and stood it nicely. 
After that he was fine and did not miss one the rest of the morning.

When the season opened (November 10th) I took him out shooting with me and I never saw such rotten work. Had a fine pointer with us and as soon as he would make a stand my dog would come running over and flush the whole bunch. This happened time and again (he only made one stand the whole day).

Next day I took him out by himself, thinking maybe the pointer had upset him. But he never stood one-flushed them all.

Now, before passing final judgment on him I thought I would write you, because you are an authority on dogs and I am not.

C. CABELL.

Ans.-I think that all your dog really needs is a week's shooting to steady him down. Very often both setters and pointers will act wild at the opening of the season and be very trying in the way they break shot, rush in and flush birds and do about every other thing that a well-broken dog should not do. They usually steady down after about a week of scolding and getting used to hunting again. 
I have a chance to get a registered Airedale free of cost, and the breed is recommended by this owner to make good dogs for quail and prairie chickens. If they are not good for that I do not want one at all. Can they be trained like a setter or pointer?

H. B. CARR.

Ans.-An Airedale can be taught to retrieve both quail and prairie chicken.

We do not compare his scenting powers with either a pointer or setter, but he is a fine dog, and if you can bring him up and take him frequently afield with pointer and setter he can undoubtedly learn the game as many of them have done.

WHICH IS THE BEST DUCK RETRIEVER?

I want to buy a good duck dog, one who will do first-class work on both land and water. I noticed a number of different kinds of dogs advertised in your magazine, but as I do not know much if anything about the different breeds of dogs $I$ am at a loss to know what breed to get.

In this country we have shooting from blinds on shore, from boats out in the rushes, and also pass shooting on dry land where a great number of the ducks will fall on dry land, in tall grass, in 
brush and even in timber where the dog cannot see the ducks very well but has to find them mostly by scent.

Now the question is, which is the best all-around dog, or breed of dog, for our purpose, and in a country where the water gets very cold, especially late in the season.

P. B. GAASS.

Ans.-Either the Chesapeake or the Irish water spaniel would be my selection for your duck dog.

\section{AIREDALE AS A RETRIEVER}

Kindly inform me if you can if Airedale dogs make good retrievers, and how do they compare with spaniels. What I want to get is a good retriever for ducks and have been informed that Airedales make good retrievers, but are they as good as spaniels for this purpose?

\section{H. C. Miller.}

Ans.-Regarding the Airedale as a retriever, I would say that he would do better as a duck retriever than the spaniel because he has the double coat and is just as good a swimmer. The Airedale can stand cold water longer and better than the spaniel. He is not as good a retriever as the spaniel, but can be easily taught. Most of my spaniels will jump right in after a stick thrown 
into the water. However, the Airedale has to be taught first of all by dropping him overboard and letting him swim to a boat until he gets to like swimming, and then you can teach him land retrieving, after which he will go after sticks thrown into the water. Of course, once he gets that down he will retrieve ducks for you as well as anything else that you might want picked up in the water.

IRISH SETTER VS. IRISH WATER SPANIET,

I wish you would tell me which one of the two dogs is the best for ducks and low ground hunting-the Irish setter or the Irish water spaniel? Where can I buy such a dog?

Joe Moroni.

Ans.-It is an open question as to whether the Irish setter or the Irish water spaniel would be the best for duck and low land shooting. Both breeds have their ardent admirers, and you will have to judge for yourself.

I know a number of men who absolutely swear by the Irish water spaniel and, of course, have a great many more friends who think the world of the Irish setter. 


\section{DOG TRAINING}

\section{A GOOD WATER RETRIEVER}

I am writing to you for information regarding the desirability of using a dog to retrieve ducks. I am a member of a club in which we have excellent canvas-back and red-head shooting, both from a pass and over decoys from a boat. Another place furnishes fine mallard, teal and blue-bill shooting, both from a pass and boat. In common with most duck-shooters, I lose a great number of wounded birds. In your opinion, does a good dog find and properly retrieve the ordinary wounded duck and bring it to a boat, as well as on land? I have read with a great deal of interest the articles appearing in Field and Stream from time to time on retrieving, and my attention has been attracted to the Chesapeake Bay duck retriever. In your opinion is this dog preferable to any other breed as a retriever, and is he suited to my needs? If so, can you put me in touch with a kennel which breeds and trains these dogs, preferably one near here, if possible?

What ought I to pay for a young Chesapeake Bay dog, well broken to both shooting from a boat and from a pass, and can I buy such a dog? If I bought one, would keeping him in the city, and at home, where there are children, have the 
same deteriorating effect on him that it does on a setter or a pointer?

\section{WatD Ames, JR.}

Ans.-A well-trained retriever should find and retrieve to boat all your wounded ducks. The Chesapeake Bay dog and the Irish water spaniel are, in my opinion, the best two dogs for the purpose. I should say that a pup of either breed would cost about $\$ 50$, and a young dog, well broken, from $\$ 100$ to $\$ 150$. I would not advise either breed as city dogs, any more than pointer or setter; they require lots of exercise, a good range, and no restrictions such as the city puts on any and all dogs.

\section{TRAINING A BEAGLO PUP}

I have several dogs, two beagles and a pointer, and would appreciate it if you would answer the following questions:

1. At what age should a beagle puppy begin to hunt well, and give voice to trail?

2. Should a dog be whipped or petted to make the best hunting dog?

3. At times I notice what appear to be small, flat worms sticking on the hair about the arms of the pointer. I have given several remedies with- 
out results. What kind of worms are they, and what is the best remedy?

\section{H. C. Voss.}

Ans.-Regarding your question concerning the beagles and pointer, would say that the beagle puppies should begin to hunt at nine months, although some of them start earlier.

Question No. 2, whipping or petting to make the best hunting dog, would say that you have to use judgment. The important thing is to be sure to have the dog know what he is being petted or spanked for.

For instance, if you wish to make him rabbit proof, call him off a rabbit trail and whip him if he persists, and be correspondingly lavish in your petting or praise when he does well with coon or 'possum.

Regarding the worms in the hair, around the arms of your pointer: Rub him with a dose of Glover's Eczema Cure under each arm pit.

\section{MUTE HOUND ON NIGHT TRAILS}

I want to find out how to train a hound so that he does not bark on night trails. I have had more than ten dogs in the last two years, and most every one barks on night trails. I have a 
156 THE AMERICAN HUNTING DOG bitch at present that I would like to break of this habit if there is a way to do it. She is eighteen months old and a fine hunter.

George W. Hodes.

Ans.-Regarding the training of your hound not to bark on night trails, we do not think it can be done, as it is in the hound blood, and it is very doubtful whether you can train out an instinct of this character. It would simply break the dog's spirit through continuous lickings, the reason for which he is not likely to understand. He is apt to consider that you are whipping him for following the trail itself, and quit hunting altogether.

A cross of shepherd dog in a hound will make him run mute. It is the only way to get a mute trailer that I know of.

\section{OVERRUNNING THE SCENT}

We hunt rabbits with two dogs, one a foxhound and beagle and the other is supposed to be the same, though I doubt it. Well, the point is, they start a rabbit and run a short distance and lose him through overrunning. They seem to go perfectly crazy, and the first turn the rabbit makes they go on by sometimes three or four hundred feet before they find out they are off trail. They 
start lots of rabbits but lose them. Now what in your opinion is the trouble?

We run at least once a week and sometimes three or four times.

I got one of my dogs from a popular kennel and was supposed to get a foxhound and beagle cross, but he looks more like a fox terrier than a hound.

L. R. Henderson.

Ans.-The overkeenness and general behaviour of your hounds can all be attributed to lack of work and experience. Fortunately they are good searchers and starters, the most important qualification of a hound. All they require is repeated opportunities to learn to hold a trail and not overrun or be deluded by the wiles of br'er rabbit.

Hunt your dogs every other day for a week and then every day for a few days. When they lose a trail do not let them range out and start another rabbit, but insist upon them working close and sticking to the first rabbit until the kill is made. By proceeding along these lines we assure you that their progress in solving the problems of the trail will be gratifying.

Crosses between beagles and hounds frequently display a good deal of terrier type. In fact, when 
you begin crossing dogs, even those as closely related as hounds and beagles, you never know what to expect.

\section{HOUND LOSES TRAIL}

I have a foxhound about one and one-half years old which I use for hunting rabbits and cottontails. While hunting he works very earnestly, but after getting a trail and giving tongue he seems to lose the trail altogether. Am sure he does not back trail. He is a full blood Walker strain foxhound. Kindly advise me of some way to overcome same.

\section{JERRY SOMMER。}

Ans.-Run the dog with an older dog for at least one season. He is hardly over being a pup yet, being only eighteen months old, and many a foxy old cottontail will give him the slip, whereas the older dog would be on to his tricks and pick up the trail again.

Your pup will get discouraged if he loses out on many trails, but he will learn all the tricks of the game and be much more encouraged if he finds that the majority of trails lead to successful conclusion in the catching of the rabbit, which will generally be the case when an older dog is on 
the job beside him. He has plenty of initiative and will not lose it by running with an older dog.

\section{FOXHOUND FOR BIG GAME}

I am the owner of a Walker foxhound puppy and being no adept at training dogs or even pretending to know much about them I would consider it a great favour to have you answer a few questions for me. They are: Do you think a foxhound can be made to be a good dog for hunting grouse and pheasants? Would you advise trying to teach him to hunt both birds and bear?

My idea in getting him was to have a dog for hunting bear and cougar, but as there are lots of grouse and pheasants here and as I only wish to keep one dog I wondered if he could not be taught to hunt all the above-mentioned game.

\section{J. L. LINN.}

Ans.-I wouldn't let your hound hunt grouse and pheasants or rabbits either. It will be hard enough to make him rabbit proof as it is. My experience in Montana has been that grouse of all kinds are easy enough to see from the mountain trails without the aid of a dog, and rabbits are very plentiful. I have shot many a one with the six-gun from horseback. Keep your hound 
pup strictly on big game and depend on a quick eye for grouse, fool hens, rabbits and the like.

\section{HOUND WILL NOT HUNT}

I have a hound that is not doing anything on trail this year, but was supposed to be a good dog when I bought him. He will not hunt, only when he strikes a warm trail, and generally follows behind your heels. He had the distemper this spring, but got over it all right, as I thought, but I have noticed him stand and go to sleep and fall over. He seems to have a good appetite, but has no ambition. HAPPY $J_{A C K}$.

Ans.-I think your dog will come around all right next year. Do not expect too much of him after getting over distemper. You are lucky to have brought him through at all.

You cannot expect a human being to show much energy the first year after typhoid-so the same with dogs with distemper.

\section{HOUND FOR LONE TRAPPERS}

Would like to ask you what breed or breeds of dogs would be most suitable to train on fur. I am a young trapper and came to the city a few years ago, and the necessary confinement is fast 
taking my health and strength, and am planning a trip into the upper peninsula of this State to regain my health and make a living from the fur bearers of that section for myself and wife. If you could give me this information as to dogs and where they can be secured, or a better place to go for fur, I would appreciate it more than you can imagine. Thanking you for advance kindness, I remain yours truly, wishing you success in your fascinating business.

Howard Braun.

Ans.-We would advise a coonhound of the Redbone or Walker strain as the best dog for your purpose. You can buy them already broken on fur, which would be your best procedure, as you are in no position to train him properly.

\section{CURE FOR GUN-SHY PUP}

How would you go about breaking a gun-shy pup? The pup is not much afraid of a gun, but still after you fire it once on a trip out he keeps his eye on you afterwards. He doesn't run home, but slinks back.

If you will be kind enough to give me what information you can I am sure it will be greatly appreciated by me.

Bernard L. Sweeney. 


\section{THE AMERICAN HUNTING DOG}

Ans.-Your pup is not very gun-shy compared to most of them that are addicted to the habit. He simply needs more accustoming to gun-fire. Tie him up alongside of you when practicing with rifle or shotgun. Don't pay any attention to him, but keep on shooting, occasionally resting gun or arm over his back when firing. He soon learns that there is nothing to be scared of.

\section{A CHASER}

Last year I purchased an English setter bitch, whelped March 2, 1914, and found that I had a gun-shy dog. To make my story as short as possible, we have broken her from this evil, leaving no trace whether in city or field.

I have had the pleasure of hunting this dog a great deal this season, and she has over eighty birds killed over her. She has the best nose of any dog in this locality, and never runs over her bird whether in the wind or away from it. I have hunted her in the Black Forests of Pennsylvania from sunrise to sunset for five straight days, and the last day with a heavy sash cord strapped to her neck, and then she worked as willingly and as hard as ever. I worked her when she had only three feet on which she was able to walk, but always with the same persistency. She is an ex- 
cellent retriever, with a very tender mouth, and if the bird is dropped, no matter where it is, she finds it. But for all this, she has three faults which are bad.

Pardon me for enumerating them, but this is the advice that $I$ ask:

1st. She will point rabbits until they run and then she will chase them. Would you advise purchasing a rabbit and keeping it throughout the year until hunting season, in her presence?

2nd. When she comes to a point, and I go in to flush the bird and find that it has run, she acts wild and rushes in and goes quartering until she finally gets the strong body scent, never with her nose to the ground, and jumps right in on the bird in one grand leap.

3rd. She locates her bird, is staunch, but when the bird flies or runs and she sees it, she chases after it. I have strapped her repeatedly for this, but repeatedly she does it again.

I would not bother with the dog, but old hunters, pot hunters, have told me she is a wonder, and I have had to refuse several large offers for her. She is not for sale at any price.

N. F. HAND.

Ans.- You have too fine a dog to dispose of for those three faults. Put a force collar on her, and 


\section{THE AMERICAN HUNTING DOG}

when she next points a rabbit, tie the cord fast to a bush or stake and flush the rabbit yourself. She will bolt after it and get punished by the collar. Steady her down in the same way when roading birds. She holds her head high because the scent is so strong. Do not whip her for breaking point. Put on a force collar, and check her with it every time she breaks. Strapping is too late and too apt to be misunderstood by her.

\section{CURING GUN-SHYNESS}

I have a puppy by Commanche Frank which I have taken out twice. She seems a little frightened when you shoot several times in succession, still doesn't run, but won't come when called. Don't know whether she is exactly gun-shy or not.

Please write me how to manage her if you have ever had any of that kind to handle.

\section{A. B. TAYLOR.}

Ans.-I think that you are making your dog gun-shy by giving her too much gun at the start. Once the habit of gun-shyness has been acquired, it is very difficult to break it. Most dogs are not naturally gun-shy, but become unreasonably frightened by unwise and careless shooting before the dog gets used to hunting. 
I would suggest your spending several weeks with her with the gun, but without shells, walking up one covey after another, until she gets thoroughly fond of hunting. It seems to me that you have enough to do at present to teach her in getting her staunch, etc., without bothering with the gun. Later on you can try killing one quail on the rise and letting her find it, until you get her used to retrieving. From that time on she will come to regard the gun as part of the game of hunting and will get over what fear of hunting she has now. 


\section{CHAPTER IX}

DOGGY QUESTIONS AND ANSWERS

REDBONE HOUNDS

I would deem it a favour if you would give me the name of a kennel owning a pack of "Redbone" hounds.

Should be delighted to read any information you may have relative to the work of these hounds on deer in the mountains of California. I have used these dogs on coon in the Southern States and have seen so-called "trailing hounds" work on deer in this State. From my limited experience with them here it seems that time does not enter into their calculations.

A great many hunters here are shouting the praises of the Airedale, naming his superior intelligence, his speed, running only warm trails, etc., as being attributes not possessed by the hound. My experience with them has been limited and for which, so far, I am thankful. Personally, I like the hound if he be well broken.

J. R. Scotr, JR. 
QUESTIONS AND ANSWERS 167

Ans.-The Redbones are from the Big Hatchie Kennels, Covington, Tenn. They have a fine reputation in the Rockies, where they hunt big game with Airedales and crossbreeds. I know of several famous packs using them either pure or crossed on some other strain to give more speed.

\section{STAGHOUNDS}

I am going to ask a few questions. I have two staghounds and one half-stag and half-greyhound and two greyhounds. The two greyhounds are eighteen months old and the other three are pups. I use them to catch jack rabbits with. The jack rabbits are not very plentiful around here. I have only caught twenty since the first of the year.

Which is the right name for the so-called "staghound" or should they be called "Scottish deerhound"? I have a book on hounds and I cannot find a breed by the name of staghound, but I find deerhounds, and my pups resemble the last named. Who is right? What can you say about the Irish wolfhound?

Herbert Middeten.

Ans.-The ancient staghound is extinct. The "Scottish deerhound" of modern bench-show classes is a large shaggy type of greyhound. The Irish wolfhound is a much heavier and larger dog 
with broader head, wire hair and ferocious terrier expression, usually dark brindle in colour.

\section{THE BASSET}

Please give me a description of a Basset hound as to size, build and markings.

\section{Arthur B. Fowler.}

Ans.-Basset hound stands low in leg like the dachshund, is somewhat larger than that dog, and is tri-colour. Of French origin, stands about 14 inches and weighs around 20 pounds.

\section{A CUR FOR COON HUNTING}

I have been thinking about buying a pup halfhound, quarter rat dog and quarter cur.

Do you think this pup will make a good 'possum and coon dog if properly trained?

This pup has got lots of spirit and looks like a hound.

Eddison Smitr.

Ans.-This pup will be a smart dog all right, but I doubt whether he has nose enough for either coon or 'possum. He could probably locate a 'possum den, but he certainly could not take up a fresh coon track, and follow it through all the tricks and dodges that Brer Coon puts into his trail.

You can get a good coon hound pup of Redbone 


\section{QUESTIONS AND ANSWERS 169}

or Walker strain for $\$ 10$. The really expensive part of him is the time you have to put in in training him.

\section{THE BEAGLE FOR RABBITS}

I would like to get some advice from you as to what kind of a dog to get for rabbit hunting. Rabbits are the game of this country, and they are plentiful. Would you recommend a beagle for rabbits or what kind of dog would you get if you were me?

J. R. Donovan.

Ans.-I should certainly advise you to get either one or a brace of beagle hounds. These dogs are rather small, standing about 15 inches, and are ideal for cottontail rabbits, as they do not run them too fast, giving the rabbit a chance to circle instead of running straight away. Their food bill also is much less than that of the large foxhound's and coonhound's.

\section{HOUND WILL NOT HUNT}

I have a hound dog which I got last spring for mink and skunk, but he will not range out and hunt, and seems to be lazy. Is there any way of making him range out? 
And should a hound range out and hunt like a bird-dog?

How old a trail should a hound follow, such as mink and skunk?

\section{Marion Henry.}

Ans. - The best way to get your dog to hunt fur animals is, to get hold of a 'possum, coon, or some other small live animal and train the dog to tracking. $\mathrm{He}$ is lazy at present because he has not had his hunting instincts aroused, and has no ardour for the chase.

Take him along with some other man's hound, going cooning-it would do wonders for him. After he has once been through a coon hunt, he will be plenty ambitious enough to hunt on his own hook every time he strikes a fresh trail.

Answering question number two-would say that a hound does not range out like a bird dog, but potters around until he strikes a scent that interests him-from that time on he is busy unraveling the trail.

Answering question number three-would say that in weather not too dry, an experienced hound can pick up a trail two days old, although they are much more likely to pick up a trail made the night before in such a plentiful and good game country. 
QUESTIONS AND ANSWERS 171

\section{SNOWSHOE RABBIT HOUND}

We have a rabbit dog, half foxhound and half beagle. What do you think of that cross? Very popular here with hunters on account of deep snows.

I should like a list of spaniel points such as you gave for beagles once in your paper.

\section{Leander P. Morton.}

Ans.-The cross of beagle and foxhound makes a very good snowshoe rabbit dog and is practically a standard combination for deep-snow hunting. The standard beagle is too small for this work, to my mind.

Regarding the points of the cocker spaniel, we would quote you as follows: Skull, 8; muzzle, 10; eyes, 7 ; ears, 4 ; neck and shoulders, 15; body, 18 ; legs and feet, 18; stern, 5; coat, 10; colour and markings, 5; total, 100.

\section{A ROAMING AIREDALE}

I have just been given a thoroughbred Airedale dog; he is now eight months old, would like to know how to make him stay at home and mind in general, as he is of registered stock, his father being registered on the other side five years ago; 
172 THE AMERICAN HUNTING DOG so am very anxious to make him mind and do some tricks while he is young.

Anything you can tell me of their good qualities and how to train him will be appreciated very much by the writer.

\section{Louis K. Fray.}

Ans.-Airedale pups at eight months old are very stubborn, wilful, don't mind and are continually running away. Keep a close watch on him; tie him up or yard him up a good deal and have patience. There's no use beating him; he won't stand for it. He will "find himself" at about thirteen months' age. Shoot him with an air rifle when he strays out of bounds and will not come back at command.

AIREDALES AND IRISH TERRIERS AS HUNTING DOGS

Please give the comparison of hunting and other qualities between the Airedale and Irish terrier. Also advise as to where information can be obtained in connection with securing a good Airedale and Irish terrier, and what book you would suggest covering information as to care, etc., of dogs.

Wm. H. G. Neumann.

Ans.-The Airedale is bigger and heavier, and because of his part otter-hound ancestry can be 


\section{QUESTIONS AND ANSWERS 173}

taught to make a good all-around hunter. The Irish terrier is mostly a family and "earth" dog for small game.

\section{THE BEST DOG FOR RABBITS AND WOODCHUCKS}

I wish you would tell me what breed of dogs or mixture of breeds you would recommend to hunt rabbits and woodchucks and make a good, all-around dog, also what material and dimensions you would recommend for a woodchuck hook?

Edgar C. Palmer.

Ans.-Beagles and Airedales are the best breeds for your purposes. A good beagle can be purchased at a moderate price from any of the dog breeders advertising. Make your woodchuck hook out of a 12-inch, three-corner file with a two-inch pointed hook at one end and an inch right turn at other. This to be lashed to a pole when dog has holed the woodchuck.

\section{THE FOX TERRIER AS AN EARTH DOG}

I was recently presented with a fox terrier puppy and would like to know if a fox terrier will hunt. If so, what? Will it retrieve birds if trained? Is it a good water dog? Can it be trained to follow a trail?

Gilman S. HarLan. 


\section{THE AMERICAN HUNTING DOG}

Ans.-You can train your fox terrier as an earth dog for small game. It can be trained to retrieve birds by any of the usual methods. It is not a good water dog because of its smooth coat, although in warm weather the foxy makes out very well and will retrieve anything that you may throw in the water or anything you point out for him to get. I do not think that it is possible to train a fox terrier to follow any trail because nature has not given him the nose. Almost all animals that leave a trail are pretty well up in the game and pull all kinds of tricks to throw off the dog, which will baffle even the keenest hound, besides which the scent is so faint that the fox terrier has no chance. $\mathrm{He}$ is, however, a very smart little dog and will give you lots of pleasure.

\section{RUNAWAY DOG}

Please give me any advice possible on the following matters. I have an Irish terrier two and a half years old, who roams away from home whenever possible. He also wishes to fight other dogs on every occasion.

$$
\text { J. H. W., JR. }
$$

Ans.-You must make him less of an everybody's dog. See that his home quarters are comfortable and that he has a place that he can call 
his own. Get your friends to treat him harshly, drive him away with sticks and stones and tread on his paws when he comes up to them. He will soon get the idea that you are his only real friend and home the safest place. Don't whip him or scold him when he comes home, as he will not get your idea at all nor realise what he is being punished for. He will only come to avoid and dislike his home and you. As to fighting, all terriers love to scrap. You will have to head him off and show him that fighting other dogs displeases you. Try also stinging him with an air gun when he tries to leave the place.

THE AIREDALE AS A HOUSE DOG

I would like to get information about Oorang Airedale terriers, as to their dispositions, conduct and actions about the house.

Gus Atwater.

Ans.-The Airedale makes an ideal house dog, has a nice disposition, is watchful and courageous and could be easily house-broken. The Oorang Kennels, of La Rue, Ohio, originated the Oorang strain Airedales, which do not differ materially from any other strain of the high-class breed. They have, however, produced a number of winning dogs for bench shows and the hunting field. 


\section{THE AMERICAN HUNTING DOG}

\section{AIREDALE AS A WATCH DOG}

Will you kindly recommend a breed of dog for general pal around a farm and for watchdog. I want one that will get up and fight a little at night, if necessary. If possible, would like to get a dog that would go along to the duck blinds and could be taught to retrieve. Have been thinking of getting one of the larger type Airedales, but would like your advice.

\section{E. G. HaRWOOD.}

Ans.-The Airedale would be the ideal breed for this purpose, as he is a natural fighter, watchdog and water dog and learns easily to retrieve.

\section{A GOOD DOG FOR THE CHILDREN}

1. What kind and where would you advise a young man buying a pet dog that ean get along with children, but need be no hunting dog.

2. I never had a dog and would like to know when to buy? Should young or old dog be bought?

3. How large a place should dog have?

4. How warm should place be kept in winter.

CrriL C. Bobione.

Ans.-1. Get an Airedale from any good breeder. 


\section{QUESTIONS AND ANSWERS 177}

2. The best age to buy is 8 months, but the cheapest, 2 months.

3. Give him the run of the house and grounds.

4. Make the kennel wind and rain tight and just large enough for the dog to stretch out in. His body heat will warm it.

\section{BEST PET DOG FOR THE HOUSE}

I would like to know the best kind of dog to get to make a pet of for the home for my wife and daughter. I want a dog that I can teach a few tricks, as well as being clean about the house; also at what age should the puppy be.

\section{H. G. MoKran.}

Ans.-The best kind of a dog to get for a pet for your wife and daughter would be either a wire-haired fox terrier or a Boston terrier. The Airedale is rather big and not handsome enough to please the women. The wire-haired foxy is an exceedingly intelligent little dog and has not the nervousness and fussiness that made the smooth fox terrier so unpopular.

I should get a pup from about four to six months old, which would cost you from $\$ 25$ to $\$ 50$. 


\section{$\triangle$ DOG FOR SQUIRREL HUNTING}

Will you kindly inform me what, in your opinion, is the best kind of dog to purchase for hunting squirrels? Would a combination hunter do, such as would tree "coons," 'possums, and trail rabbits as well?

In this part of the country (the Cumberland Mountains) the squirrel hunting is excellent, but the hunting is confined chiefly to the negroes and the mountaineers, who use common hounds and mongrels. My little boys are eager for the sport, and if I get a dog for them I want to have something better than the "suck-egg" variety of hound.

JoHN M. MoBryde, Jr.

Ans.-A good family dog that could be taught to tree squirrels is the Airedale. He is faithful, courageous and affectionate, and is a splendid watchdog, and can be taught retrieving and sight hunting of all kinds; he soon learns to tree mark a squirrel.

\section{THE AIREDALE AS A PHEASANT DOG}

Will you kindly give me your opinion as to making a bird-dog of an Airedale? In my part of the country we have only pheasants to hunt. 
QUESTIONS AND ANSWERS 179

and I would like to know if it would pay to try and train an Airedale pup to point and hunt them.

\section{WhitNey P. Howes.}

Ans.-We think an Airedale would be a very good breed for the purpose, as hunting pheasants with either pointer or setter ruins the dog.

The pheasant runs ahead of the dog, and will not stand point, and the result is encouraging both setter and pointer to break point and flush.

A small beagle is one of the best dogs to trail them with, as he keeps right on going and puts the pheasant into the air, where it can be shot.

Running your Airedale with either beagle or bird dog will teach him the trick, and make a good dog for the purpose.

RABBIT, COON AND WILD-CAT DOG

Would you please advise me as to what kind of a dog to get. I want a dog to hunt rabbits, coons, wildcats and grouse. Is there a dog that could be trained so? What do you think of an Airedale pup? Could I train it myself?

Also, would the 22-calibre long rifle cartridge be large enough for wildcats, not cougars?

R. P. LaWRence. 
Ans.-If you will cut out the grouse from your dog's list of accomplishments you will get more satisfaction out of a coon hound than any other dog for combined rabbit, coon and wildcat in a country where such game abounds. An Airedale, however, can be trained to hunt all of them, as many a man in Maine has done, and, in your State, he would probably make a good selection, although he certainly would have to run hounds for a year or so to get enough experience, or, if you have the time, you might train him on coon, bobcat, etc., by letting him track them and tree them; also have a mix-up with them, so as to get thoroughly used to this kind of a game. After that there would be no trouble in his following a reasonably warm scent of any of these animals, although the Airedale does not make a good cold trailer.

The 22-calibre long rifle is plenty large enough for bobcat, and so is a good club!

For sights, we would recommend a combination globe and ivory bead front sight, a folding bar sight in the rear notch and a folding tang peep on a tang of the rifle stock. 


\title{
QUESTIONS AND ANSWERS 181
}

\author{
MARING A DOG RUN MUTE
}

As to making a dog run mute, there is a pretty houndish looking dog occasionally that will almost still hunt. Airedale and hound have made a good cross for a gentleman here. The bull terrier and hound also make good. As an allaround small dog, I like an Irish terrier and beagle. Now you said that whenever a fellow was stumped to write you. I am badly stumped. I have been trying for seven years to get a rabbit dog that I can enjoy, but to no avail. Getting stung every time I send away and so on has almost got me cornered. I have several hundred in it, too. What I would really like is a dog like those New York long-ear or symmetrical red bone of the American standard or medium light dogs that are rough enough to hunt all week, hard, from sun up to sun down, resting of nights; that are willing hunters; that don't hunt too far away from one; who seem to know where to look for a rabbit; and that can and will take a track run the night before, trail it up to noon and jump, trailing straight, not going over and over their tracks or poking around, but trail them up at a fair rate of speed for trailing. When one jumps, 


\section{THE AMERICAN HUNTING DOG}

run at a speed not great enough to pop a cottontail right in his hole, but what is considered medium speed; be able to run 75 per cent to the gun or hole or patch, not over-running like the standard American hounds do, and being a good homer and not too easy to take up with strangers. I would prefer a bawler or long clear cry or a deep bay or a coarse chopper, but no yap, yap. I thought since you can find these qualities in some dogs, having one or two of them there might be among such dogs as the Buckfields or such of those strains that are up in New England that would be like the foregoing. I have a dandy cocker spaniel who seems bright and as nice coated as the dogs I see in the magazines, who has hunt in him, but I can't get him to look for rabbits when with me. I would like to get him to retrieve them, but can't. Will probably discontinue using the spaniel as a brush dog and take one-half Irish and one-half beagle again, as I know they will work better, and are easier to teach retrieving.

I broke an old-time hound in this way so that whenever he caught a rabbit he would bring it back in his mouth, and the method I used was by rolling a ball when the pup was four months old.

Gus WhitMer. 


\section{QUESTIONS AND ANSWERS 183}

Ans.-We are glad to get your letter about the Airedale hound cross running mute. I have seen a good many of these dogs but have never seen one work, and was under the impression that they barked on the trail.

Regarding teaching your spaniel to retrieve, have you run him with a beagle after rabbits yet? I have had several spaniels and they were all good dogs to put up rabbits. After starting the rabbit they would follow, barking continually. As they do not go very fast, the rabbit circles. To make him retrieve, I would begin by teaching him to "fetch," or making him sit down and open his mouth to take something. After he gets that into his head, by successive steps you get him to take anything you hand him at command; next to pick it up at command, and, finally, to go and hunt for something at a distance and to bring it to you. If this is done with a dead rabbit from the first, I believe you will have no trouble in teaching him to retrieve rabbits.

\section{HOUND AND AIREDALE CROSS}

1. I have a nice English beagle hound one year and five months old, and a friend of mine has an Airedale terrier which he would like to cross with my beagle bitch. Do you think it would make any 


\section{THE AMERICAN HUNTING DOG}

kind of a good dog, i.e., for coon or opossum? My beagle is good on rabbits, but the Airedale isn't trained to hunt, he's only a trick house dog but full of grit. This friend of mine says it will make the best all-around coon dog on the market.

2. Do you know of any one that has crossed a beagle with an Airedale?

3. What or which is the best way to train a dog to hunt and tree a coon? What breed of a dog?

4. I know of a dog that tongues on a rabbit trail and also on quail and pheasants, on the latter two she generally gets on her hind legs and looks ahead when she gets near them; the dog looks like a beagle hound only her hair is kind of kinky.

\section{J. J. Pudliner.}

Ans.-I have seen several crosses of Airedale on hound, and, like all direct crosses, the resulting pups are very uncertain. Most of them are just plain worthless, having neither of the good qualities of the parents. A good many throw back to one side or the other, having just enough hound in them to spoil their looks as a terrier, or just enough terrier in them to spoil their efficiency as a hound. Once in a while a cross turns 


\section{QUESTIONS AND ANSWERS 185}

out to be a wonderful varmint dog, so that you can count at least a couple out of every litter that will be worth while.

SIZING UP THE PUPPY

Can you give me any enlightenment as to whether there is any way of telling that a puppy is well bred?

I recently became owner of a puppy whose mother is an English setter, father is also supposed to be an English setter; both are black and white, also my puppy, but she has short hair, more like a pointer; has a good nose, long ears, and is very prettily marked.

Can you tell me if there is any way of knowing if I have a well-bred dog?

J. A. LitTle.

Ans.-All setter puppies are short-haired when very young. The feather does not begin to show until the fourth month. Ears at two months, however, should have curly, silky hair and coat should be silky. Get, if possible, mother's pedigree. Dog will show up whether cross or not at about four months of age.

CHOOSING A DOG

Which of the following would be the most preferable dog for watching, ratting and general pur- 


\section{THE AMERICAN HUNTING DOG}

poses : Airedales, Irish, Scotch, Yorkshire, Skye, West Highland or fox terriers, or any other dogs that may be better for the above purposes that I have not mentioned?

Wm. H. Neumann.

Ans.-We prefer the Airedale if you want a dog that can kill a tramp instead of merely barking at him. In cities or thickly settled suburban districts the Irish and fox terriers would be preferable. If there are children about, Airedale or Irish make good playmates that will not get cross or snap.

\section{MAKING THE PUP CHICKEN PROOF}

I have an Irish setter pup about six months old. I have to keep him tied up most of the time except in the evenings. I have a bunch of tame chickens, and if the dog is loose he will immediately start after them and if left loose I believe he would kill the bunch.

I killed a chicken near his house the other night and he almost went crazy trying to get at the chicken.

Is there any way I can cure him of this habit, a whipping don't seem to do him any good.

J. W. Gorman. 
QUESTIONS AND ANSWERS 187

Ans.-Regarding making your setter pup chicken proof, you should be glad that he is crazy to get at them, as it shows that he is a proper bird dog.

It is, however, essential to make him chicken proof, and the best cure is to hang a dead chicken about his neck, tieing it to his collar and leaving it there for a few days until he gets to hate the scent of chicken.

I would, however, put this off until he is well broken on quail, or he may lose interest in the entire bird-hunting game.

\section{AMBITIONLESS PUPPY}

I enclose a picture of a dog which I have had five days on trial. I believe that she might have been a good dog had she been fed so that she would have had strength to hunt. She was tired out, no desire to hunt, but would lie down at every chance. In the company of another dog she worked better, but alone she was too listless to do anything. I am enclosing you a picture of the dog so that you may see what she looked like. It cost me in the neighbourhood of $\$ 6$ to have her. I do not censure Field and Stream, but am desirous of letting you know how I fared.

O. H. Strouse. 


\section{THE AMERICAN HUNTING DOG}

N. B.-The picture does her more than justice, as she was even "skinnier" than she looks on the photo. I would be pleased to know your opinion as to whether she was in condition to be sent on trial. Are kennel dogs always sent in such an emaciated condition?

Ans.-In my experience of buying puppies I find that they often arrive from the kennels as a mere bag of bones. Of course, every ounce fed the dog while in the kennels lessens the profit made on the dog.

It usually takes from three weeks to a month to feed a dog to put him in good condition. Of course, you could hardly expect her to show any ambition to hunt until somewhat fed up. It is possible also that she may have worm trouble.

I hope you kept her long enough to give her a fair trial. You are under no obligations to pay for a dog until satisfied as to whether it would work well or not. Some of them develop gunshyness later, and you can never decide from a snap trial.

\section{BUYING $\triangle$ HUNTING SETTER PUP}

I am writing you for advice in regard to the purchase of a dog. I am in the market for a setter puppy. It does not seem to me that I shall ever 
need the high-strung, bench-show type of animal, but rather a common-sense, easily kept, useful kind of dog that will be acceptable around the house, and also be ready to give me some fun next fall, when the season opens again. Perhaps I am wrong but I have an idea that a dog from some nearby kennels here in the northern and eastern States would stand this climate better than one from the south or west. And in such a case also I might possibly go to choose the dog personally.

As to whether it should be a red, Gordon or of the other variety, I am hoping to rely on your advice. And as to which kennels or where I am also at sea.

Dr. Edw. R. Evans.

Ans.-We would not advise either Gordon or Irish setters for your purpose. You will probably use him mostly on partridge and woodcock in the country around Utica, and the red dog gets lost too easily, whereas the black and white English setter can be spotted in a moment, and has a generally better makeup than the Irish setter, and is easier to train. The Gordon is practically extinct in this country, though a few of them are working down South.

I should advise purchasing a Laverock dog, because you are much more likely to get one with 


\section{THE AMERICAN HUNTING DOG}

grouse-hunting instincts already deeply rooted in him. Puppies of bench-show sire and dam are apt to be apathetic-that is, their hunting faculties have lain dormant for one or two generations, and you have to awaken them through a long course of free hunting through puppyhood.

It is very much better to start off with a puppy who will point almost as soon as he can waddle before he gets into the habit of chasing and running wild, which it is very hard to break him of. Scout was such a puppy and was never any trouble at all to train. Such dogs are easily purchased from grouse dog kennels, who breed them exclusively for woods shooting work. Let the kennelman select the puppy for you, as he can pick out a good one much more surely than you can. Do not try to get a grown dog-almost all the good ones are snatched when very youngfrom two to four months-price about $\$ 25.00$, and raise him yourself.

$\triangle$ WORD FOR THE IRISH WATER SPANIEL

The Irish water spaniel is a dog that stands pre-eminent for all forms of water retrieving. His coat is practically waterproof and affords him absolute protection from the coldest water. For nose he has a Chesapeake skinned a thousand 


\section{QUESTIONS AND ANSWERS 191}

yards, and, what is equally important, you will always find him just the same; he never gets stubborn or sulks like our Maryland friend. He will also make good on quail or other upland birds, though I will not (being candid in the matter) class him with a well-trained setter or pointer.

I believe I can safely say that I am one of the largest breeders of these dogs in the United States, and I have only just begun. I have just about concluded the purchase of one of the most noted prize-winners of this breed that could be found in Ireland, and with him come two splendid bitches.

Percy K. Swan.

\section{THE LLEWELLIN SETTER}

Are all English setters white and red spotted; are all Llewellin setters black and white, with tan tips over eyes and on lower part of upper lips, and which is the best breed of dogs for quail hunting?

J. E. Gillespie.

Ans.-All Llewellins are English setters, the name Llewellin referring to a special strain developed by Mr. Llewellin. So many of them were imported into our country that a large division of English setters in the country are more or less Llewellins. A dog showing Llewellin on both sides 
192 THE AMERICAN HUNTING DOG

would be classed as a pure-bred Llewellin, the colour markings have little or nothing to do with it. For quail any English setter is good, purebred Llewellins winning more stakes than outcrosses and Laveracks.

\section{ORIGIN OF THE GRIFFON}

Could you please tell me the origin of the pointer, griffon and foxhound?

\section{Vincent Nixon.}

Ans.-All three developed from the coursing hound of the Middle Ages. The early pointing hounds of $1750-1800$ had the bushy tail of the modern foxhound curled on high, thin muzzle and other houndy characteristics which changed as the breed was established as a pointer. The griffon is a French breed undoubtedly descended from the Russian wire-haired pointing hound. He resembles a shaggy pointer with wire hair and docked tail.

\section{THE COLLIE AS A POINTER}

On the farm I was on out in the West, the farmer owned a nice pure-bred collie dog, and I would like to know if same could be converted into a prairie-chicken dog. This is about the only thing I would like him for, because I can get all 
the snipe, ducks and jack-rabbits I want myself without the aid of a dog. If I could just get him to point them alone I would be satisfied. He has one good trait: when he flushes a prairie chicken or a covey of them he runs up to them easy and directly they take the air he stands stock still and does not attempt to chase them. But he has the bad fault of ranging around wherever he likes, and being on the open prairie he runs about pretty well as much as he likes and where he likes. I think that with a collar and chain on I could teach him to keep close to me and not range anywhere from 5 to 500 yards away from me. I would appreciate any information on this matter you could possibly give me.

P. Dedosser.

Ans.-You never could teach the collie to find and point birds, for he has not the nose nor the hunting instincts. Better get a setter pup and keep him at the farmer's. He would be glad to do so free for the sake of having a good bird-dog to use.

\section{SETTER OR SPANIEL?}

I am considering the purchase of a pup in either a field spaniel or setter, as there are many quail on the farms near my home, partridge in the woodlands and occasionally a few ducks stop in the 


\section{THE AMERICAN HUNTING DOG}

ponds nearby, or I go for them on the river after the ponds freeze.

Which would be the handiest all-around dog for a small home?

Will a field spaniel point quail and partridge as a setter would, or will he invariably rush in and flush them? At what price ought I to get a fair pup that I can train myself?

Henri Schonhardt.

Ans.-Field spaniel will run and flush quail, and you have to hunt too close to him for that reason, so that he cannot range to find a covey. Better get a good Irish setter for your purpose.

\section{A GENERAL HUNTING DOG}

As a reader of your magazine for several years I have had much enjoyment, and many good suggestions from it. Seeing your kind offer of information, I would like a little. I am looking for a dog. I want the dog that will give the best returns for hunting and as good for the home as possible-an all-purpose dog. He must work on ducks, rabbits and squirrel. What's the breed?

Edw. E. Doughtт.

Ans.-We advise an Irish setter as the best combination dog for this mixed hunting. 
I would like to get your advice about dogs, especially in regard to Irish setters.

I have read in your magazine, as well as in others, advice to always purchase pups whose parents are actual field and hunting dogs-not just bench and show dogs. Will you advise me what would be a good breeding of such a pup, and could you give me the names of one or more breeders whose kennels are headed by good hunters, as well as well-bred dogs-parties on whom I could rely.

I have a letter from Walter McRoberts, in which he says that he intends to breed Highland Rose to Sammy Oge, owned by F. E. Morrow, Hawkeye, Ia. Are both of these dogs field dogs, and what do you think of that breeding?

RoBt. L. Rutan.

Ans.-Either the Law, St. Cloud or Morty Oge stock is good. Irish setters make equally as good hunters as bench dogs, as they are not bred exclusively for the bench as some English setters are.

BUYING AN IRISH SETTIER

I want a red Irish setter, but find it impossible to obtain what I desire. I realise the fact 


\section{THE AMERICAN HUNTING DOG}

that if the dog I want was broken he would cost me something like $\$ 300$, which I don't care to pay. I would prefer breaking the dog myself and then I would know him and he would know me. In this event I would think that it would be a good idea to buy a puppy. I want a pretty dog and one that has plenty of sense and well bred; that is, of good stock, and that will not be too large when grown. I also would like to have a Gordon setter or Llewellin.

Will you please advise me of some reliable person that I could get this dog from?

\section{B. Gaskill.}

Ans.-I would advise writing to either Dr. Charles A. Gail, of Rutland, Vt., who can probably put you in touch with some good Irish setter pups, or to the Ulster Kennels, of Ridgeton, Miss., who are advertising puppies.

Regarding a Llewellin setter, P. I. Appleman, of the Thoroughbred Kennels, of Atlantic, Ia., can get you some good pups.

I do not know of anybody at present who is breeding Gordon setters.

\section{BAD HABITS IN A CROSS-BREED}

(1) My dog has two habits which I would like to cure him of. 


\section{QUESTIONS AND ANSWERS 197}

When I am hunting he will hunt on ahead of me and then stop and wait for me to come up. And I have to cheer him on again. How can I break him of it?

(2) I would hardly call this a habit:

He will not bark when chasing or trailing an animal or game, and seldom barks when animal is treed.

I think he is a mixture of pointer and fox terrier. He is a fine hunter and rat dog, and points birds and quail sometimes. What shall I do?

\section{Edgar Lewis.}

Ans.-The two habits you mention are characteristic of a dog of this kind. You cannot expect a mixed breed to specialise as well as a thoroughbred.

The pointer in him evidently makes him mute on game. This is a matter of instinct and inheritance.

Regarding the other fault, we would not try to break him of it. You do not want a dog of this kind too far ahead of you, and you cannot expect him to work up birdy country the same as a thoroughbred. You had best keep him a good deal in your company. 


\section{CHAPTER X}

\section{DOG DISEASES}

\section{CHOREA AND ITS TREATMENT}

I have an eight-months-old Llewellin setter that has some disease that causes him to jerk apparently in his left front leg, but his whole body jerks after taking exercise.

He had distemper when a pup and has had this disease since.

Please advise if there is any cure for him, as he has the appearance of a fine dog.

E. L. HEDRICK.

Ans.- Your pup has chorea, which is an aftermath of distemper and it will take a long while to cure it.

I would recommend Fowler's solution, and for pups it should be diluted in the preparation of one-half an ounce of Fowler's solution to one ounce and one-half of water. The commencing dose is sixteen drops of the foregoing mixture for breeds of medium size. This should be given 
three times daily in the food, and the dose should be increased one-fourth after every third day.

After having given the mixture thirteen days, stop for three days and resume with the same amount of dose as you stopped at. This you continue until the dog has taken forty-eight drops. After this there should be a second stop for three days, when the use of the medicine should be resumed, beginning with forty-eight drops and decreasing every three days with one-fourth of the total dose. This treatment is continued for about three months.

\section{A TOUGH CASE OF CHOREA}

I have been advised to write you for advice concerning my dog.

I have a very fine English setter dog, just a year old to-day. Was a very active and precocious pup up to about the middle of October last, when he showed symptoms of distemper.

I took him at once to a very good veterinarian, who gave him three inoculations of distemper serum at intervals of a few days apart. I never saw a quicker or more complete recovery, and he gained nicely in appetite and flesh for about ten days or two weeks, when he began to show symptoms of chorea in his right shoulder mus- 
200 THE AMERICAN HUNTING DOG

cles. Have had the same veterinarian treat him again for a month and he grew steadily worse, but the trouble has never affected any other part, or set of muscles, just the right shoulder.

The leg is held up at the elbow tightly against his upper leg muscle, but only when he is standing or exercising, and jerks continually.

When he lies down he always lies on the affected side, and when asleep is perfectly quiet. Does not touch foot to the ground, but suffers no pain from it, yet his sense of feeling in the leg is $\mathrm{O} . \mathrm{K}$. That is, it is not paralysed. Muscles are slightly shrunken from habitual disuse, but not noticeably. He got down to skin and bone and so helpless I had to carry him to and from his kennel.

I then gave him Fowler's solution of arsenic, commenced with three drops, increased to fifteen, then back to nothing, twice. His appetite came back and he gained in every way except that continual muscular twitching and jerking in the right shoulder only, and that decreased considerably in severity. I am continuing the Fowler's treatment, but for the past month I can see no improvement in the muscular twitchings. At present he feels fine, is apparently in perfect 


\section{DOG DISEASES}

health, aside from that, eats well, sleeps well and is in good flesh.

If I could get wise to something that would knock out that muscular spasm, I think he could and would use his right leg again $0 . \mathrm{K}$. It has never become flexed or set in one position. He stretches a great deal and straightens it out himself to normal position, but pulls it up again when he gets up, and the spasms keep it jerked up when he lies down.

Can you think of anything more I can do for him? I can't think of destroying him, and my wife would not allow me to anyhow. She cares for him like a spoiled child.

Hints on treatment, care and diet would be greatly appreciated and reciprocated when possible. His sire is Grouse B. O. (30163), winner of the New York State championship trials at Middletown last fall, and also Pennsylvania champion. Dam a Whitestone Searchlight bitch, Onondaga Gypsy (36502), a beautiful individual.

MARK G. Brown.

Ans.-Regarding your puppy, would say that I think you are on the right track with Fowler's solution, only you have not continued it far enough. I would advise an increase of three 
202 THE AMERICAN HUNTING DOG

drops at a time up to forty-five drops; then rest three days and drop back three drops at a time until you get back to nothing; then a week's rest and recommence the treatment. So long as the dog is feeling well and shows no watery eyes, you can continue the treatment for several months. It usually takes about six months to a year to get the best of a case of chorea such as the one you described.

\section{DEWCLAWS}

I have a young setter bitch that has dewclaws on hind feet which get very sore when hunting in stubble and brush; I wish to know if they can be removed and how? She had a litter of eleven pups, three of which have dewclaws also, if they can be removed would it be better to do so while quite young?

Should a well bred setter have dewclaws?

\section{H. G. KuKeLIE.}

Ans.-A good veterinary can remove dewclaws, but if you attempt it yourself it will likely make the dog lame for the resulting sore is slow in healing. The claw itself can be snipped until it is quite short. Snip it little by little with sharp wire cutters. With pups under three days old the dewclaws are just cut off with sharp scissors. 


\section{DOG DISEASES}

203

IRAIN-SICK DOG

I would like to know if you could inform me as to the cause of my setter getting sick. When I take him on train he works for about two hours then he gets so sick that he lies down. He has the symptoms of a dog with blind staggers, and he is never in that condition only when I take him away. I am sure he is not affected with worms in any way. Do you think this trouble could come from his nerves? If you can enlighten me in any way or refer me to any one, please do so.

Thomas L. Williams.

Ans.- Your dog is evidently train-sick and nervous. Probably did not digest food from nervousness while on train. Do not use him afield until at least a day after the train journey. Put a little lime water in his food.

\section{BRONCHITIS}

I have a very fine setter bitch, about four years old, and about three months ago she began to cough a little. I thought she was taking distemper, so tied her in a dry place, and began to give her Glover's distemper cure. I gave her two bottles, but she did not seem to get any bet- 


\section{THE AMERICAN HUNTING DOG}

ter. She had a very good appetite all the time, but her throat seemed to be sore, and seemed to hurt her when she would eat, and sometimes she would choke badly. She has become a little better, but still is not well by any means. She coughs very little when she is still, but when she begins to take exercise, she will begin to cough, and it is not an unfrequent thing for her to fall flat and stretch out as if dead when she has one of these coughing spells. She is a very fine dog, and nicely trained.

O. B. Winston.

Ans.-From what you say, we are inclined to think that your dog has one of the forms of bronchitis.

Kennel her in a dry place, and give her a tablespoonful of cod liver oil (Scott's Emulsion is good) in her bowl of food at each feeding.

\section{CAR-SICK DOG}

I am writing you in regard to a Llewellin pup that is about $4 \frac{1}{2}$ months old. She gets very sick when she goes for a ride in the auto. She vomits and slobbers all over herself. Is there anything I can give her, or do to prevent this?

Forrest Leatherman. 
Ans.-Pup is too young for automobile rides and evidently has weak stomach. Dogs vomit very easily. Best leave her home until she is at least a year old.

\section{BLACK TONGUE}

For sore mouth or black tongue a sure cure that a friend of mine has used with much success is as follows: Give a tablespoonful of castor oil and then swab the mouth out three times daily with a wash eomposed of tincture of iodine one ounce, carbolic acid twenty drops and glycerine one ounce, mixing well before using.

\section{R. L. LUCAS.}

SPRAINED HIP

I have an Airedale pup, eight months old, and he has been lame in his left hip for two months. I had the local veterinarian look him over and he says the pup sprained or pulled a ligament loose in the socket, and advises me to keep the pup tied up to avoid too much exercise, and give the hip a chance to heal, but it would be a slow cure. This seems probable, but as he is so young, and growing so fast, his leg does not develop, for he carries it most of the time. Would you advise the use of iodine on the sprain, or 
206 THE AMERICAN HUNTING DOG apply liniment and massage his hip? He walks on his leg some, but not enough to develop it.

P. W. BaUer.

Ans.-Regarding the case of sprained hip with your dog, I would simply keep him from too much exercise and let nature heal it up. These cases are slow and usually last about two months, but your dog will surely get well if he is not overexercised.

I would not use liniment or iodine.

SPAYING PUPS

We would not advise you to spay bitch pups.

Spaying takes all of the ginger out of them, and as a general rule makes them worthless and without ambition in following the trail or fighting varmints.

SORE EYE

I have a pointer puppy, ten months old, whose eyes have been inflamed for about two months. They do not seem to pain him, but are very much blood-shot, and in the morning they have in them considerable matter. His general condition is excellent.

I have used a solution of boric acid, wiping 
the eyes about three times a day, but the condition does not improve?

What do you suggest?

Wm. De L. Worsley.

Ans.-Your pointer probably has catarrhal conjunctivitis, a disease of the mucous membrane of the eye. It is self-limiting and he will get over it in time, but you must keep down the inflammation as much as possible. We suggest an eyedropper and both eyes washed three times daily with borax in camphor water, ten grains to the ounce, and lids to be rubbed with vaseline at night. Keep out of light for a few days and open his bowels with a dose of castor oil and feed only meat broth and broken stale bread baked to a golden brown. He should show improvement in a week's time.

\section{EAR CANKER}

I have a spaniel and he has something the matter with his ears. He is always scratching them or shaking his head, and yelps as with pain when they are touched. His ears have an offensive odour, and are running more or less all the time. I have bathed them with salt water, but it does not seem to help any.

I would like to know what is the matter and 
208 THE AMERICAN HUNTING DOG

also a remedy, and would be obliged if you could furnish me with such.

A. R. JACKSON.

Ans.-Your spaniel has external otitis, or ear canker, probably from overeating and lack of exercise as basic cause. See that he gets a good run at least twice a day and goes out with you whenever you go for a walk. A mild solution of boracic acid in lukewarm water poured into the ear passage once a day will take care of the interior inflammation, and whatever sore part of the ear can be reached with the fingers had best be rubbed with zinc ointment for eczema, which you can get at the drug store. Hockwalt gives the following ear lotion: Goulard's extract of lead, 1 oz.; laudanum, 1 oz.; fluid extract witch-hazel, 1 oz.; water, 2 oz. A teaspoonful warmed and poured into the ear once daily. Try this if the boracic acid solution does not appear to be strong enough.

\section{DEAF BEAGLD}

I have a Beagle hound puppy nine months old, and about six weeks ago I first discovered he was deaf. Can there be anything done for him? His head is not sore, and I am unable to find anything out of the ordinary. He is out of a first 


\section{DOG DISEASES}

field trial winner, and I am very desirous of saving him.

F. F. Foster.

Ans.-Ears may be plugged with wax down in the passage above the drum, in which case a lotion of a teaspoonful of glycerine and a teaspoonful of bicarbonate of soda and a little sweet oil in two quarts of water will loosen it. Put in fountain-syringe bag and wash out dog's ear three times a day for a week. If he begins to shake his ears and show signs of pain he may be getting canker of the ear and will need a lotion of a crystal of permanganate of potash in lukewarm water, enough to redden solution well. Drop in a teaspoonful, daily, warmed to blood heat.

\section{EAR CANKER}

Taking advantage of your kind offer of advice re arding dog ailments, would like to describe symptoms and ask advice about a rabbit hound a year and a half old.

The ears are full of a soft wax which seems to annoy him, causing him to go about shaking his head. The ears are not sore now but have been. Two different doctors say the trouble is canker and have prescribed formaline and glycerine, 
alcohol and boracic powder, and finally $I$ have tried sweet oil and witch-hazel as warm as he could stand it in a syringe. He is better but not cured. Can you suggest anything else?

I have learned that a few drops (4 or 5) of turpentine on sugar was an excellent thing for expelling either tape or other worms.

C. A. Brown.

Ans.-Regarding external canker of the ear in your rabbit hound, we would suggest treatment with oxide of zinc ointment, or Goulard's lead mixture, which you can get at any drug store.

We think the ear trouble is a form of eczema, and would suggest changing his diet of corn bread and feed him instead with stale bread baked until golden brown in the oven, broken up in his bowl with dog meat broth poured over and a little well cooked meat. Cut out oatmeal, fresh bread and any non-nutritious food likely to cause eczema.

\section{PARALYSIS}

Would you allow me a suggestion in your treatment of the case of Mr. Thos. Irgens? I do not want to be forward with this suggestion, but I have had excellent results in similar cases where you have a paralysis or simulated paraly- 
sis in the hind extremities of dogs. In addition to your treatment, I give a few drops of Fowler's solution of arsenic four times daily, commencing with two drops and gradually increasing to four drops four times daily. Increase a drop daily until the four drops are reached, then continue until improvement has reached a high degree. I am not a dog veterinary but just a dog lover, and treat my own dogs. This treatment has given me excellent results in two such cases as Mr. Irgens described.

\section{E. G. Replogle.}

\section{ITIS}

I have a pointer bird pup that is subject to fits while hunting. He never has a fit only shortly after you have flushed a covey of quail and shoot two or three times, then he will stop, look around as though he was scared, drop his ears close to his head, clamp his tail and start to run, making possibly two jumps, and then run in a small circle two or three times, and then falls over. He will lie for two or three minutes, kicking and slobbering, and his head generally draws back over his side or neck.

He has never had but one fit in a day's hunt except once, when he had two within twenty minutes. 
The dog is eleven months old and has been having these spells for the past two months, having nine in all. You can hunt for hours without affecting him unless you get into a covey of birds. The first few spells did not seem to affect his hunting, as he would hunt as well after the spell as before, but lately I have noticed that it seems to take all the pep out of him.

$\mathrm{He}$ is good size, very fast, and covers considerable territory for a young dog. I will appreciate any suggestion you may have to offer.

W. S. Whatley.

Ans.-Dog is a mere pup and evidently of the nervous type. Give him a heavy meat diet, cod liver oil, tablespoonful once a day. Needs feeding up and possibly cleaning out of worms.

To relieve: plunge in hot water if near home.

I have a female St. Bernard, six years old; one year ago she started having fits, and has had them at almost regular intervals two or four weeks apart, but the last two were in one week, and seemed to be worse than the others. She holds her hind leg up, walks a piece, falls down, looks around at herself, crying, and then goes into a fit, which lasts a few minutes, opens and closes her mouth; when she gets up she is dazed; 
if water is put into her mouth she laps it; the day before she has a fit she makes a queer noise in her throat, and after it is over she coughs, at other times she is well and lively. I have had her examined by three veterinarians, with no result, treated her for worms, tapeworm, indigestion, nervousness, and she is not constipated; has no heart trouble.

\section{T. J. M.}

Ans.-Give 10 grains bromide potassium in a little camphor water 3 times a day and put her on mild diet of dog-meat broth and broken up pieces of bread baked to a golden brown in the oven. Give plenty of milk and little exercise for two or three weeks.

\section{HOOKWORM}

(1) English setter dog, fourteen months old, is big in bone, but does not take on flesh, although he has a ravenous appetite. I have given him areca nut about three times since he was six months old, and on each time he passed a bloody mucus, which did not stop until he was treated by a veterinarian. This dog seems to be in good health, but when hunted for about three hours becomes very weak and sometimes can hardly walk. What treatment would you suggest? 
214 THE AMERICAN HUNTING DOG

(2) Setter bitch, three years old, has a dry, hacking cough until hunted for about half an hour. Her eyes usually run when she coughs. Advise treatment.

Ans.-(1) Possibly your dog is infected with hookworms. Better have a microscopical examination made of the fecal matter to see if it contains the eggs of the hookworm.

(2) Examine her throat for goitre; if no goitre is present give a good expectorant cough syrup, which can be obtained from your druggist.

WORM REMEDY

Would you be kind enough to inform me what and how much to use as a worm remedy for a four-months-old Pomeranian?

Dr. M. Benson.

Ans.-One-fourth teaspoonful of buckthorn syrup once a week.

WORMS

I have obtained a fox terrier and find he has a bad case of worms. He seems to feel fine in every other respect. What can I do for him?

H. T. Hutchison.

Ans.-Buy 5 cents' worth of pumpkin seeds, mash and boil half an hour and serve on his food. 
Also give a teaspoonful of syrup of buckthorn once a week.

\section{PUMPKIN SEEDS FOR WORMS}

Read some time ago an article stating a good treatment to give a dog having worms.

Want to know how often to give him pumpkin seeds, and how much at a meal.

\section{HoMer RAMSDELL.}

Ans.-For a mild case of worms and to keep them down, would advise syrup of buckthorn once a week, a teaspoonful. For a bad case of tapeworm get five cents' worth of pumpkin seeds, boil and divide in two parts. Put one on feed and follow in three days with the other in case worms are not cleared.

ARECA NUT

Please advise me what to do for my Scotch collie puppy, just six weeks old. About two weeks ago she had worms and I gave her some areca nut. Perhaps I gave her too much, as she is now paralysed; that is, she is unable to walk and cannot stand up on all four feet at the same time. She eats well and has been in good spirits during the last few days. Can she be cured, and if so, what treatment is advisable?

D. R. J. 
216 THE AMERICAN HUNTING DOG

Ans.-If the puppy is suffering from the effects of areca nut, she will no doubt be either entirely well or dead by the time you receive this answer. Never give areca nut to a young puppy. Try Fowler's solution if still alive.

\section{CORES FOR TAPEWORM}

I have a young English setter bitch a little over two years old and until reading your book, "Airedale, Setter and Hound," I had been treating her for worms, using a patent worm expeller, but instead of getting better she has steadily been growing worse. Not knowing the difference, I thought it was just ordinary worms, but after reading your book and examining her feces I find that it is tapeworm; every time she will pass at least six or more of those flat, white, lively objects that you so clearly describe. Otherwise my bitch is all right, only her appetite is not very good and she keeps rather poor. Since reading your book I have tried both the turpentine and the pumpkin seed but without seeming effect; I have now decided to try the areca nut also, but would like to have a little more detailed information about how to go about it before undertaking the cure. I would 


\section{DOG DISEASES}

dislike very much to lose her as she gives every promise of becoming a great hunter.

\section{O. S. Ellevold.}

Ans.-Regarding the case of tapeworm with your setter bitch, I would say that I think you are up against either the areca nut or extract of oil of male fern treatments. These are both powerful poisons and would kill the dog as well as the tapeworm unless gotten out of the dog's system promptly.

The areca nut dose is one grain to the pound weight of the dog, following within two hours with a tablespoonful of castor oil. This should do the business. If not, about a month later, follow with the fern oil treatment, which is 16 drops for a medium sized breed of dog like your setter bitch. Follow in two hours with a generous cathartic in both treatments. In both cases, the dog must be fasted twenty-four hours before administering the medicine.

N. B.-Mr. Ellevold gave his dog 45 grains of areca nut powder mixed with flour and butter and followed with a tablespoonful of castor oil in two hours. Six hours later the dog passed five yards of tapeworms. 


\section{GASTRIC DISTEMPER}

I have an English setter pup five months old, and for the past two weeks he has been on the sick list. It started out in a lameness in his hind legs and fever. Thought it was rheumatism myself, but our veterinarian says that pups don't get it.

The last few days he has been almost paralysed in his hind quarters, and on his belly there are sores that are full of matter. Am at a loss to know how to treat him. I treated him for distemper, as I noticed a slight discharge from his eyes, but not his nose. I used Elkay's Distemper Remedy, and gave him a pill every two hours for a couple of days. The pills are composed of 1 grain of acetphenetidin, a derivative of acetanilid.

Do you suppose that this treatment would cause the paralysis in his hind parts and sore spots under his belly?

$\mathrm{He}$ is a kennel-raised dog and his sleeping quarters were slightly damp during some severe storms that we have had out here. Would that have anything to do with his condition?

Have also treated him for worms, and he seems to be rid of them. Have kept his bowels open with laxatives. He does not seem to be very sick now, 


\section{DOG DISEASES}

but he doesn't move around much on account of the lameness, I suppose.

Have had several good dog men look at him, but they can't seem to agree as to what ails him. Some say he is poisoned, others say distemper, while others say worms.

\section{Thos. Irgens.}

Ans.-Your dog surely has one of the forms of distemper. Get him indoors in a warm, dry place with good comfortable sleeping quarters. Discontinue the distemper remedy, as it will not reach the form he has. Inject 2 c.c. of distemper antitoxin in each hind leg. Keep down fever with sweet spirits of nitre, 10 drops in half cupful of water, one teaspoonful every time his fever rises. Feed up well on meat broth and stale bread, with a tablespoonful of cod liver oil once a day. Dog will pull through if constitution is sound. Otherwise, especially as you have begun treatment very late, you may lose him in about ten days more.

\section{BEST DISTEMPER PREVENTIVE}

I am taking the liberty of asking you to inform me where I can obtain information on a positive and best way to cure distemper of dogs. I have a very fine setter pup of the Gladstone and White- 
stone stock, and she is going to be a very fine hunter.

I am particularly afraid of distemper on account of a little interbreeding, although my pup is in excellent condition and strong. But when that disease grips them, all is up.

A. C. Stevens.

Ans.-The best preventive that we know for distemper will be to send to the Pasteur Laboratories, 366 W. 11th St., N. Y. C., for a tube of fresh anti-distemper serum and a hypodermic needle.

Two cubic centimetres of this serum are injected into each hind leg of your pup between the thighs, and will immunise him from two to four months.

The period when distemper seems to be rife in the South is January, February and March, and we should certainly advise immunising him some time in December.

\section{DISINFECTING FOR DISTEMPER}

Please advise best disinfectant for use in dog house and lot where dog had distemper.

How soon will it be safe to put another dog in the pen?

G. A. Hembree. 
Ans.-For disinfecting the kennel where your dog has distemper, I would begin with a thorough hosing down with water. After the sun has dried this, follow with a spraying of listerine over the walls, floor and runway yard. The best way to get this sprayed is to buy a fifty-cent galvanisediron tree sprayer which holds about a pint of the solution, and same can be sprayed out in the form of a fine mist, which settles evenly all over the surface sprayed. Follow this in about a week with a second spraying of creosol, a teaspoonful to the quart of water. Let in plenty of light; no germ can stand the direct rays of the sun. In dark, damp places the distemper germ can live about two years.

\section{GASTRIC DISTEMPER ?}

I have a pup about seven months old which has. been sick for four and five weeks and gradually gets weaker. I first thought it was distemper, but treated her for same which did no good. Also treated her for worms which did no good. She has been eating fairly well for a sick dog. For two or three hours after she is fed sometimes she will howl as if in pain and will scratch at her neck and shoulder occasionally. Have been feeding her on raw eggs for past week, but don't think she is 
getting any better; if any change, is growing worse.

Any information regarding this case will be appreciated.

I have another puppy by "Cords Count Gladstone" out of "Cincinnatus Mollie." What do you think of his breeding?

O. B. TAYLOR.

Ans.-We are rather puzzled in making a diagnosis of your dog's case. It seems very much like distemper, but the fact that it has run for four or five weeks seems to put distemper out of the game, because this disease is usually over in fourteen days and the dog is either convalescing or dead at the end of that time. It is possible that he may have a light case and be withstanding the attack of the germ.

I would suggest a hypodermic injection of two cubic centimetres of either Pasteur's or Moore's Anti-Distemper Toxine. Shoot this into the inside of each thigh of the dog.

I lost a dog from distemper with very much the same symptoms as yours. The dog had the gastrical form of distemper and howled pitifully after every meal.

Regarding your puppy by "Cords Count Glad- 


\section{DOG DISEASES}

stone" out of "Cincinnatus Mollie," would say that this is very good Llewellin.

AN AFTERMATH OF DISTEMPER

I have a Llewellin' setter dog about four years old at present who had a hard case of distemper two years ago and since that time his head "jumps" and his jaws continually "pop" and every week or so seems to have "risings" in his head and his eyes run. There seems to be no one who can tell me what to do for him, and, as I love to have him with me, but it is almost impossible, as there is such a bad odour about him, I thought I would write you, having seen some questions answered in the Field and Stream. I am enclosing stamped envelope and would be very glad if you rould tell me what is the matter and what to do.

\section{W. H. Scort.}

Ans.-We would advise you that your dog has a form of chorea which is an aftermath of distemper. The best cure for it is Fowler's Solution, beginning with three drops a day in his food and increasing three drops each day until forty-five drops are reached. The dog is then rested a week and the treatment decreased, beginning at fortyfive drops until back to three again. The treat- 
ment takes about a month and a half and restores his nervous system to normal.

\section{MANGE CURE}

I note inquiries for a cure for mange. To your thousands of readers, I will say, regardless of what veterinaries or any one else may suggest, use the following for a sure cure:

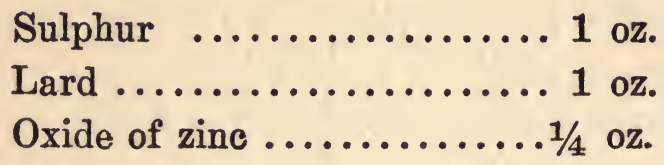

Before applying in form of a paste, wash all affected parts with soap and lukewarm water. Use treatment every other day for five treatments. Itching will stop almost immediately after the first application, and the growth of hair will return in a very short time. This treatment cannot fail.

\section{RALPH L. HUNTER.}

\section{CURE FOR RED MANGE}

Please tell me what to do for red mange on a dog. I think it is red mange. The sores break out on his neck and run and get sticky. Would like to know about diet, too. I suppose candy is not at all the thing to give him.

J. Peetrey Clark. 
Ans.-Sounds to us like eczema. Reduce his diet to plain stale bread baked to a golden brown broken in dog meat broth, and rub him over with Kenwyn Koat Kure, Boving's Eczema Cure, or Glover's Mange Cure.

\section{A CURE FOR MANGD}

I note an inquiry for cure for mange. Try equal parts sulphur, gunpowder (black) and lard. Use as an ointment. Should be cured in six weeks. If it.is eczema try sumach bobs as a wash. Put on as hot as can be used, for a few days.

MILES G. EASTWOOd.

\section{MANGE DIP}

(1) Give information re Mc's Count Whitestone (21555) necessary to register puppies by him? (2) What is good mange dip? (3) What is the difference in symptoms between mange and eczema? (4) What is a good treatment for eczema?

Ans.-(1) As the dog is registered, all that is necessary in registering a puppy by him in the F. D. S. B. is to give sire's name and registration number. (2) Dissolve in an earthen vessel three pounds of Lewis lye in one quart of boiling water, add gradually five pounds of sulphur and stir with a wooden paddle until the sulphur is dissolved. 
226 THE AMERICAN HUNTING DOG

Stir this into forty-five gallons of water, after which add eight ounces of pure sulphuric acid and stir. Immerse the dog for about one minute, using care to keep the mixture out of the eyes and ears. (3) There is practically no difference in the symptoms, you always have eczema when the dog has mange. Outside of a few cases of eczema, in which there would be no itching, very little redness and no pustules, could you be sure that it was not mange without a microscopical examination. (4) The treatment depends upon the cause. Exercise moderately, keep the bowels open and feed a well-balanced diet. The use of resorcin, salicylic acid, sulphur or zinc oxide ointments or vaccine may benefit.

\section{ECZEMA CURE}

I have an eleven months' old setter pup who for the past month has been scratching himself most of the time. I examined him thoroughly, and find evidence of rash on his stomach, also two spots which look like pimples, on his back. I judge he has a touch of eczema. I have started to give him a teaspoonful of sulphur on his food at each meal, and will wash him twice a week with Epsom salts in water, which remedy I saw in Field and Stream.

Please tell me if this treatment is right, or your 


\section{DOG DISEASES}

suggestions. His hair is beginning to come out, though I am inclined to believe that this is his puppy coat coming out with the warm weather.

\section{JOHN F. CARD.}

Ans.-That pup of yours surely has got eczema, and it has progressed so far that your Epsom salts are too mild. Send for a bottle of Kenwyn, Glover's or Boving's coat cure and dope him all over with it. These are the best I know, and I have tried a lot of remedies, for Airedales are very subject to eczema.

You must change his diet right off. At his age he needs three meals a day. Breakfast, a little oatmeal, a broken-up dog biscuit, some table scraps, and meat broth from his meat kettle poured over the whole works. Lunch, table scraps, pieces of stale bread baked to a golden brown in the oven, and meat broth poured over the whole of it. Supper, table scraps, a dog biscuit broken up, a chunk of dog meat from the kettle, and some pieces of stale bread baked. A diet like that will drive away the eczema quick, aided by the coat cure. He should not lose his puppy coat of hair-none of my setters do-it is one of the effects of eczema. 


\section{CURING SOFT SORES}

I have a valuable beagle that has sores coming on her that I can't cure. They come as little blisters and break and then form a scab, and when it's dry I can pull the hair out, too, and it heals up then and breaks out again somewhere else. It started on her ears first, and it's about well, and it's coming all over the under part of her neck and on the body and under armpits. She scratches and makes it spread more. I don't think it's canker, for it don't eat, but it's a soft sore; otherwise she is fine. I used muriate of iron and Glover's mange cure, but she can't stand it. She nearly goes crazy when I rub it on. I would be glad to have you tell me just what it is and how to treat it. I only feed her table scraps. I wash her twice a week and use Creolin Pearson afterward, and disinfect her kennel and runway wherever she touches twice a week, but it seems to get no better. The reason I don't believe it's canker is because it don't crack her ears open and I have squeezed open the blisters.

H. G. Stahl.

Ans.- Your beagle has eczema. You must change her diet, as it comes first of all from food that does not agree with her. Cut out table 


\section{DOG DISEASES}

scraps, oatmeal, and corn bread for the present and feed her stale bread baked to a golden brown in the oven, plus broken-up dog biscuit (old grist mill), with a dog meat broth poured over it. Get her a pound of 12-cent shank meat twice a week and boil in a kettle. Pour the broth over the bread and biscuit and feed her a little of the meat at the night feeding. Wash her sores with strong solution of Epsom salts and send for a bottle of Boving's Eczema Cure. It often works in obstinate cases of eczema that yield to no other treatment. Get a box of sulphur and cream of tartar tablets at the drug store and break one up and mix with the food of her night meal.

ECZEMA CURES

I have an Irish terrier and, although the dog seems in good health, she is constantly troubled with eczema, more so, of course, in the summer.

A. L. FARLEY.

The eczema cure gotten out by Mr. F. C. Boving, Hot Springs, Arkansas, is effective.

However, to eradicate eczema you must begin first of all with the diet of the dog. Both Irish and Airedale terriers are very subject to it if they get much oatmeal, corn bread, potatoes and such 
230 THE AMERICAN HUNTING DOG starchy heating foods in their diet. I find that the terrier does best on stale bread baked to a golden brown in the oven with dog meat broth poured over same-one or two dog biscuits can be broken in-and very little table scraps. This seems to bring the coat prime and with one application of the coat cure the eczema disappears.

ECZEMA

Being a reader of your magazine, and noting your generous offer to answer questions, I am going to ask you some.

I bought a two-year-old hound from a kennel about a month ago, and he has very little ambition. He will not work unless the trail is very hot, and then does not run right, but gives up too quick. I've been giving him worm medicine and found out he had them.

This is what I cannot understand; he will stop and scratch for five minutes at a time. I know he has no fleas or lice.

He eats well and would eat all day if he got it, but I feed him right, I think.

He was very poor when I got him, but is picking up some now, but he just wants to lie in his kennel.

WM. R. KREPPS. 
Ans.-Your dog has come down with eczema. If he is scratehing behind the ears and under the armpits it has extended along far enough to give him a dose of eczema remedy and a change in his diet.

Cut out all starchy and indigestible foods and give no fat with his meat. Five cents' worth of dog meat, twice a week, boiled in a kettle, and feed him at present twice a day. A breakfast meal of stale bread baked a golden brown in the oven, one dog biscuit, and dog meat broth poured over it. For supper, table scraps, piece of meat from dog kettle about the size of a tablespoon, a bone, one dog biscuit, and broth from kettle poured over the same.

For his coat, rub over with Boving's Eczema Remedy, or Glover's Mange Cure.

\section{SETTER SHEDS HAIR}

I have a 16-month-old setter and lately he has started to shed hair so much that in some spots he has hardly any left. He scratches and bites himself and keeps rubbing his paws over his eyes and nose. I have been unable to find any fleas on him, although he has small sores which bleed when he scratches them too much. He also has very little ambition for a young dog and gets tired eas- 
ily. Also his smell seems to be affected, as when I had him out last week he went right by two quail without smelling them. I give him a bath twice a week but at that a bad odour arises from him and also from the cloth he lies on.

Also when he points out a covey and they are shot at he does not keep point but starts to run around where the birds have been, searching for any that may have been shot. Is this the right thing for him to do or is he supposed to stand still? I have a lot to learn about how to train dogs and would like your advice.

Adolph Cesar.

Ans.-Your dog undoubtedly has a bad case of eczema and you must, first of all, change his diet. You are feeding him too much corn bread, oatmeal, potatoes and other non-nutritious foods that are very hard for a dog to digest. Don't give him any of them for at least a month. Feed him exclusively on stale bread baked to a golden brown in the oven, over which is poured rich dog meat broth from the dog meat kettle which you must keep handy. At least twice a week buy him five cents' worth of good dog meat shank-cut with bones. Boil these in the kettle, also adding any bones and meaty table scraps. He requires three 


\section{DOG DISEASES}

meals a day, the breakfast meal being a dog biscuit, bread and meat broth; the second meal, one dog biscuit at 12 o'clock, fed dry; the third meal at night-dog biscuit broken up, stale bread, a few table scraps, a good helping of meat from the kettle, a couple of bones and broth poured over all.

Now to treat his coat. Rub him all over with either of these three remedies-Glover's Mange Cure, Boving's Eczema Cure or the Kenwyn Koat Kure.

You will find that his ambition will returu after the eczema is cured, but it will take at least two weeks to heal the sores, and a month or so before the hair begins to come back.

\section{RUPTURE AND WORMS}

(1) Pointer bitch, ten weeks old, has a navel rupture the size of a hazelnut. What is the cause of same and the best method of treatment? This puppy was supposed to have been treated for worms about four weeks ago. I have had her for about two weeks and have fed her dog biscuit, meat, cereal and milk. A few days ago she passed a large number of worms. Should I treat her for worms or keep on feeding as I have been? (3) Do you think the dog biscuits were the cause 
234 THE AMERICAN HUNTING DOG of the puppy passing the worms? (4) Please advise how to use the vaccine treatment for distemper, and where same can be procured.

(5) If this puppy has had one treatment, could it be the cause of her eyes mattering?

(6) What should I do for her eyes? (7) Would fleas on a puppy make its eyes sore and mattery?

Ans.-(1) The cause of navel rupture is the failure of nature to cause a union between the abdominal muscles. Would advise having a veterinarian suture the abdominal muscles together after having scarified the edges. (2) Treat for worms and continue the diet as long as it is a wellbalanced ration. About two-thirds well-cooked meat, the remainder cereals and vegetables, with enough liquid to make it a semi-solid, is quite a suitable diet.

(3) Not necessarily.

(4) Your veterinarian or druggist can procure one for you, and it should be used according to the directions on the package. (5) Possibly. (6) Place one drop of a fifteen per cent solution of argyrol in the eyes four times a day. (7) Not if the puppy does not scratch around the eyes, injuring them, in an effort to allay the irritation produced by the fleas. 


\section{DOG DISEASES}

RUPTURE OF THE ABDOMEN

I would like to have your advice on a pointer pup seven weeks old that has a swelling and bag under it right where the navel is. It is as big as the end of your thumb and looks as if it might be full of water. I can press it back easily but it comes right down again. Is there anything I can do to put it up or could it be opened? It doesn't seem to hurt the pup and all the litter were the same way.

\section{J. Bradly.}

Ans.-These pups all have umbilical hernia, and you are in for an operation. I think you should have a veterinary do it.

The trouble will not cure itself, and requires the intestinal protrusion pushed back and the hole in the abdomen and skin stitched with catgut. Usually two stitehes are sufficient.

Pups must be fed only bread and milk for a day and fasted for half a day before, with the bowels cleaned out with sweet oil. They are then ready for the operation.

The part should be sprayed with chloroform or sulphuric ether to deaden the pain, after which the sack can be opened, the parts protruding pushed back, the ring through which they come 


\section{THE AMERICAN HUNTING DOG}

sewed up with two stitches, using catgut. After that the skin can be sewed up with silk. An opening should be left for draining, and iodoform or other antiseptic used to keep the wound free from germs.

Keep the pups in a warm place with fresh bedding. It takes about five minutes for the operation, and three weeks for recovery. It can best be done by a competent surgeon or veterinarian.

\section{AIREDALE HUNTING STOCKS}

Before buying an Airedale I would like to know of the leading Airedales of the country, and the names of the best dogs, both hunters and show stock, and wish that you would refer me to the proper authorities. Yours sincerely,

WhitNey P. Howes.

Ans.-The best-known Airedale hunting stocks are the Oorang, Culbertson, Kenwyn, Colne, Loudon Swiveller, etc. The English York Kennels usually show up on most Airedale pedigrees about three or four generations back, and Master Briar or his get somewhere in the fourth generation back. 


\section{DOG DISEASES}

I have a setter pup, thoroughbred, seven weeks old, and have been advised to have the end of its tail cut off so that it will hold straight when the dog is pointing.

Kindly advise if there is any truth in this, also when tail should be cut, and if it should be done by a vet.

\section{A READER.}

Ans.-Upcurving tail in a setter is a sign of poor breeding. We never heard of docking the tail to cure it. If your dog is of good blood his tail will stand straight, either somewhat pointing up at a slant or straight out in line with backbone when he points.

\section{REGISTERING SETTERS}

I have a pair of English setters, a male and female, and they are good hunters. Now and then people will ask if they have a pedigree, which they have not. And I would like to get them registered, and get a pedigree if possible, but don't know how to go about it.

Lours SorHeIM.

Ans.-To have your dogs registered, you must either have the pedigree of dam and sire for three 


\section{THE AMERICAN HUNTING DOG}

generations back, or else if you know the names of both dam and sire, send them in to the Field Dog Stud Book, in care of the American Field, Chicago, and they will advise you if these are registered pups.

If dam and sire have already been registered, it is easy to get a registration certificate for the pups, the fee for the same being $\$ 1$.

IRISH SETTER REGISTRY

My dog, Pat IV, A. K. C. 190066, is a mahogany red, and no white except a small white star on breast; he is extra large and has beautiful shape. My bitch has white toes and white breast, and in each litter of pups there has been one white and red spotted one, more white than red; looks more like an English setter, and they are the largest of the litter and seem more birdie than the others and are beautiful dogs. Where does the white in the Irish setter come from? Some people think an Irish setter can't have any white on them and be thoroughbred.

M. B. Colurns.

Ans.-A white spot on breast is always allowable on the coat of an Irish setter. The white colour there probably comes from an English setter cross in the pedigree of your dam.-The West- 
minster Show (N. Y.) has a class for Irish setters.

TO REGISTTER AIREDALES

Will you kindly give me the address of the parties whom I should write to in regard to registering an Airedale dog?

\section{Slaman.}

Ans.-American Kennel Club, 1 Liberty Street, New York City. The registration fee is $\$ 1.00$, and pedigree for three generations back is required.

\section{REGISTERING POINTERS}

I have been referred to you for information regarding the registration of a pointer bird-dog.

Four weeks ago I got a female pointer pup șix weeks old. The dam is registered, but the sire is not, although his owner has the pedigree of the litter, made out at the time he was sold. He was whelped May 26, 1906.

I would like to know if it is too late to register him.

I have known and hunted this dog for the past five seasons and would have him registered, if possible, in order to register my pup.

Since coming to Oklahoma I have owned sev. 


\section{THE AMERICAN HUNTING DOG}

eral pointers, but as long as they were good shooting dogs their pedigree didn't interest me.

The dog's owner gave me the litter pedigree yesterday. He has owned the dog since the dog was a puppy, so there is no doubt of his identity. L. H. JoHnson.

Ans.-Not too late to register sire of your pup. Three generations on both sides required. Registry number of dam is sufficient. Would suggest entering puppy in Field Dog Stud Book.

\section{TO REGISTER YOUR DOG}

To whom do I write to have a dog registered and what is the fee?

B. E. Moritz.

Ans.-Sporting field dogs are registered with the Field Dog Stud Book, care of American Field, Masonic Temple, Chicago. Other dogs with the American Kennels, 1 Liberty Street, New York City, fee $\$ 1.00$.

\section{REGISTERING BIRD-DOGS}

I have two English setters, supposedly very well bred, and the former owners although not kennel men, claim they are eligible for registration. I have the pedigrees of both, but not a registration number appears on either of them. 


\section{DOG DISEASES}

I would be pleased to have you advise me if it will be possible to have these dogs registered, and if so, who to take the matter up with.

O. B. Martin.

Ans.-Send the pedigrees with $\$ 1.00$ fee for each dog to the Field Dog Stud Book, care American Field, Monadnock Block, Chicago, Ill.

They will send you registry certificates with number if the pedigrees show the dogs are eligible for registry.

\section{BREEDING DOGS}

Hunting is my hobby, and I want to breed my own hunting dogs in the future. In establishing a small kennel of my own I can afford to be very exclusive on account of its size, and can therefore use only the very best blood lines obtainable. Will you kindly answer the following inquiries for me?

1. Where is Ch. Mohawk at stud?

2. Do you know any more celebrated or better English setter sire?

3. What special strain of English setter bitch would you send to a Mohawk II dog in order to produce a pup classy enough to use as a sire in the future in my own kennel?

D. S. MoElroy。 
Ans.-1. Ch. Mohawk is dead, but the Babblebrook Kennels offer four famous sons of his who have been recent field trial winners-Babblebrook Joe, etc.

2. Mohawk II was a fine dog, but there are also good representatives of the Gladstones, Whitestones, Eugene M., etc., who must not be overlooked.

3. I would send a Whitestone or Gladstone bitch to the Mohawk sire.

\section{LINE BREEDING}

(1) Would it be too close to breed a bitch to a dog, the dog's dam being a full sister to the sire of the bitch? (2) What is meant by line breeding and outcrossing? (3) Is the beagle Gusty, the dam of Florienne, registered; if so, give number?

Ans.-(1) Not in a single instance or where the mating is made with some definite purpose that is to strengthen or perpetuate certain traits. Line breeding may be defined shortly as the combining of the blood of a certain individual without the direct use of that individual. Thus, the mating of cousins would be line breeding. The closest cross of line breeding occurs with the mating of half-brother and half-sister. Most breed- 


\section{DOG DISEASES}

ers confuse the terms inbreeding and line breeding. In fact, there are really only three types of inbreeding, that is, crossing the blood of a single individual. They are inbreeding a sire to his own daughter, a dam to her own son or full brother and sister together. Where similar blood lines are used in combination different from the above, they might be termed, as a rule, line breeding. An outcross is obtained when a deviation is made to a dog or bitch possessing blood lines entirely dissimilar from those appearing previous thereto. (3) Not registered.

POOR DIET-POOR CONDITION

I have an Airedale about ten months old that is having trouble with small warts coming out all over the roof of his mouth and on his lips.

The dog does not seem to be as lively as he did a month ago and wants to be in the house most of the time (although he sleeps out nights), lying down instead of running around out of doors as previously. He does not eat much and spends a great deal of his time scratching his neck and biting himself all over, although he does not seem to scratch his ears; it all seems to be on his neck or body; also rubs his head along on the ground some when outdoors, rubs his front paws over his eyes 
quite a bit, which makes the lower part of his eyes look red and inflamed. His ears look clean and no discharge and I don't find any sign of any skin trouble on outside. He is washed every week or two with antiseptic soap, so don't believe he has any fleas.

He had a wart on tongue about six weeks ago (the only one he had then) and I had it removed; since then the small warts have appeared and he acts as stated previously.

\section{H. M. BULI.}

Ans.-We advise change of diet. No bones for at least two months; no oatmeal, no corn bread. Feed him stale bread baked to a golden brown and broken up in his bowl with rich meat broth poured over it, twice a day. Get a pound of soup meat once a week, twelve cents a pound, and cut up to make a nice broth. Boil a long while. Feed him a little of this meat once a day and pour broth on bread. Give him one Old Grist Mill dog biscuit once every two days and a tablespoonful of cod liver oil on his food at every meal twice a week.

\section{OBSTRUCTION IN INTESTINES .}

During the hot spell of this summer my Gordon setter suffered several severe convulsions from 


\section{DOG DISEASES}

some cause which I could not discover. After this trouble he refused to eat anything at all for two weeks. His appetite has now returned, but he fails to get enough nourishment from his food and is getting thinner all the time. Bowels are extremely loose and stools formless and clay-coloured. I have been feeding small amounts of well-cooked meat, dog biscuits, etc.

PaUl N. Prass.

Ans.-From your letter it seems to us that the dog needs a thorough clearing out with castor oil.

There is evidently some irritating material in his bowels which must be dislodged, as at present it sets up an irritation akin to dysentery in human beings. Try clearing him out with castor oil-about a tablespoonful at a dose, and feed him a bland diet of meat broth and stale bread baked to a golden brown in the oven. Give him no table scraps or vegetable foods at present.

\section{FOR LOSS OF APPETTTE}

About six weeks ago I bought an Irish setter pup; as near as I could judge about ten months old. He was very poor and I attributed that to lack of food. But after he had slowly taken on a. very little flesh he suddenly, about two weeks 


\section{THE AMERICAN HUNTING DOG}

ago, began to get poorer again. Now he has lost all ambition and when I take him out hunting he will only show interest when he strikes a very. warm trail. He lies about most of the time, showing little interest in anything. He hasn't much of an appetite. He seems run down generally, with a loss of vitality. We have fed him two or three eggs cooked with a piece of bacon, and white bread a day. Also he has a pail of cows' milk near him. He doesn't seem to like raw meat. He has grown very fast, as he is a very large dog. I was told that this might affect him.

If you could give me any suggestions I would be thankful. I don't know whether you can draw any conclusions from my explanation, but I thought, from your large experience, you might understand the case.

Daniel Goodman.

Ans.-Either the dog's diet is wrong or he has worms. Try feeding him exclusively on stale bread baked to a golden brown with dog-meat broth poured over it, broken up dog biscuit and a tablespoonful of cod liver oil on the mess. Feed four times a day a big bowl full. Also treat for round worms with a teaspoonful of syrup of buckthorn once a week and watch his passages for dead worms. Also if he has a tape-worm you will 


\section{DOG DISEASES}

note squirming white fragments in his feces and, if so, give him five cents' worth of pumpkin seed mashed and boiled for an hour and then mix in his food.

\section{FOOD FOR BITCHES IN WHELP}

I have a bitch in whelp and wish to inquire from your kennel department the best food ration for her while carrying and after the pups arrive.

She is on a farm where she can have plenty of skim milk, mush, etc., rather difficult to procure meat scraps and there is very little meat from the table scraps. I have never believed that any of the prepared dog foods were any good for this kind of a job.

\section{E. A. ReNwIOK.}

Ans.-Regarding food for your bitch in whelp, I would say that you will have to feed her up with a good deal more meat than she is getting now. She needs plenty of strong, nourishing food. I would advise as a diet during this time five cents' worth of shank or dog meat from the butcher, twice a week, the same to be boiled in a kettle kept specially for her use, the broth from this meat to be poured over a mixture of table scraps and stale bread baked to a golden brown in the oven; also two feedings a day consisting of a 


\section{THE AMERICAN HUNTING DOG}

chunk of meat about the size of a tablespoon, and a bone for her to gnaw on. You can give the skimmed milk for a mid-day feed, with perhaps a dog biscuit broken up into it, about a pint of milk to the feeding. I would not do very much with corn-mush at this time if I were you.

\section{CHRONIC INDIGESTION}

I have a good rabbit dog which is in excellent health, has a good appetite and drinks plenty of water, but he is continually opening and shutting his mouth.

I was told that he had the thumps caused by over heating.

If possible from my explanation please tell what is the trouble and what will cure it.

$$
\text { W. P. Rece. }
$$

Ans.-You do not say how old your rabbit dog is, but if a puppy, it is quite likely afflicted with worms, in which case give a teaspoonful of syrup of buckthorn until cured.

The symptoms seem to be of indigestion. Do not feed him too much corn bread or potatoes.

\section{HOWLS IN HIS SLEEP}

We have a red cocker who seems to have the nightmare. 


\section{DOG DISEASES}

Occasionally during sleep he begins to breathe heavily, then starts moderate growling which quickly develops into furious yelling. He is nine years old, very active, always has been voracious, seems well and in good general form. We suspect worms or possibly overfeeding or both.

If you can suggest something to help this little chap, and incidentally everybody else within a mile, we will be very appreciative.

\section{H. WRIGHT}

Ans.-Regarding the red cocker who is afflicted with the nightmare, in our opinion the dog has some obstruction in the intestines.

If you will try a good clearing out with castor oil, followed with a good diet of meat broth and stale bread, kept up for a week, I think that under this treatment he ought to show signs of improvement, because the carrying on at night is undoubtedly either indigestion or bone splinters in the intestines. Clear out worms if not relieved.

\section{FEEDING YOUR BEAGLE}

I have a beagle pup about seven months old. $\mathrm{He}$ is perfectly healthy except for some itching trouble. He scratches and bites himself a great deal and the hair on his under side is either com- 
250 THE AMERICAN HUNTING DOG ing out or being scratched out. There are no sores on him and he has no fleas. If you could tell me what to do it would oblige me greatly.

\section{ROBERT I. WOODBURY.}

Ans.-Your beagle undoubtedly has eczema and your first move will be to change his diet. Cut out all starchy foods, such as potato scraps, cornbread and oatmeal, and feed him for some time to come on a diet of stale bread baked to a golden brown in the oven, with broth from the dog meat kettle poured over it and a little meat (about a tablespoonful) added. For a dog of this size you will need five cents' worth of good shank-bone meat twice a week. Boil this in a kettle which you will keep for the dog and use the broth from this on his bowl of food. To this diet may be added greens from the table and one dog biscuit a day. Save all stale bread and keep same in a crock and bake brown as needed.

Now as to his coat-rub him all over with any one of the standard eczema cures or mange cures. Boving's, Glover's and the Kenwyn Koat Kure are all good, and a good home-made dope would be flowers of sulphur in crude oil. 
CONCRETE UNDERGROUND DOG KENNEL

Underground dog kennels constructed entirely of concrete are in use now in Colorado. The climate in this state is extremely warm and very cold in season. Consequently the greyhounds kept for hunting coyotes suffer greatly from the heat if not properly housed. One of the largest kennels in the state is on the Rocky Ford cantaloupe farm, and it was here that the first underground kennel was built.

The kennels are built into the ground somewhat like caves or dugouts. From the surface an incline leads to the floor of the kennel, which is about six feet square and built to accommodate four dogs. The incline is so constructed that rain and water cannot reach the floor. A semi-circular drain connects to a sewer pipe and carries away all rain and water. The roof of the kennel is below the surface of the ground and ventilators placed so as to keep out moisture and let in fresh air for the dogs.

Carroll E. Williams.

BLUE AND ORANGE BELTON MARKINGS

In regard to English Setters and Blue Beltons I was told by one man that they were the same breed and another man says they are different 
breeds; another man spoke about an Orange Belton and I tried to find a book which told of different breeds, but could not. I only found three breeds of setters, English, Gordon and Irish.

W. S. Palmer.

Ans.-The terms "Blue Belton" and "Orange Belton" refer to the markings of English Setters. When a dog is so bred that he is flecked all over with blue or orange ticks, many of which are so large as to become streaks and so indeterminable as to mingle with the white body colour of the dog, it gives the effect of blue or orange and has been named "Blue Belton" and "Orange Belton" respectively. Both the Llewellin and the Laverack branches of the English Setters are so marked in certain strains. 



\section{BOOKS FOR THE DOG LOVER}

THE COMPLETE DOG BOOK

By DR. WILliaM A. BRUETTE. The history. characteristics and peculiarities, care, breaking and breeding of ninety-two varieties of dogs. Illustrated. $\$ 3.00$.

\section{YOUR DOG AND YOUR CAT-How to Care for}

Them

By ROY H. SPAULDING, D.V.M. Goes thoroughly and practically into the care of animals, with special reference to the conditions in which pets are commonly kept. $\$ 1.50$.

THE AMERICAN HUNTING DOG

BY WARREN H. MILLER. Concerns the various types of hunting dogs and the choosing, breaking, feeding and housing of them. Illustrated. $\$ 2.50$.

BIRD DOG DAYS

By HORACE LYTLE. Treats bird dogs and the field trials for them in an authoritative and entertaining manner. Illustrated. $\$ 2.00$.

BREAKING A BIRD DOG-A Treatise on Training By HORACE LYTLE. Full and practical guidance in the form of an account of the author's actual experience in training a puppy into a fine bird dog. Illustrated. $\$ 2.00$.

THE STORY OF JACK and Other Dog Stories

By HORACE LYTLE. Tales of humor, pathos and excitement sure to delight animal lovers of all ages. Illustrated. \$1.50.

\section{DUMB-BELL OF BROOKFIELD}

By JOHN TAINTOR FOOTE. The unpromising son of an old champion unexpectedly makes good in one of the best dog stories ever written. Frontispiece. $\$ 2.00$.

POCONO SHOT

By JOHN TAINTOR FOOTE. Drama and tragedy mark the gripping and appealing story of the best bird dog in the Pocono hills and his owner. \$1.25.

D. APPLETON AND COMPANY 



